\title{
SITUAÇÕES DE CONFLITO: UMA APLICAÇÃO DA TEORIA DOS JOGOS \\ EM SALA DE AULA
}

\author{
ROSELI ROCHA TEIXEIRA
}




\section{Situações de Conflito: \\ uma aplicação da Teoria dos Jogos \\ em sala de aula}

Roseli Rocha Teixeira

DISSERTAÇÃO APRESENTADA

$\mathrm{AO}$

INSTITUTO DE MATEMÁTICA E ESTATÍSTICA

DA

UNIVERSIDADE DE SÃO PAULO

PARA

OBTENÇÃO DO TÍTULO

$\mathrm{DE}$

MESTRE EM ENSINO DE MATEMÁTICA

Programa: Mestrado Profissional em Ensino de Matemática

Orientadora: $\operatorname{Prof}^{a} \operatorname{Dr}^{\mathrm{a}}$ Cristina Cerri

São Paulo, outubro de 2018 


\title{
Situações de Conflito:
}

\section{Uma aplicação da Teoria dos Jogos \\ em sala de aula}

\begin{abstract}
Esta versão da dissertação contém correções sugeridas pela Comissão Julgadora durante a defesa da versão original do trabalho, realizada em 07/12/2018. Uma copia da versão original está disponível no Instituto de Matemática e Estatística da Universidade de São Paulo.
\end{abstract}

Comissão Julgadora:

Prof $^{\mathrm{a}}$. Dra ${ }^{\mathrm{a}}$. Cristina Cerri - IME-USP

Prof. Dr. Pedro Aladar Tonelli - IME-USP

Prof ${ }^{\mathrm{a}}$. Dra ${ }^{\mathrm{a}}$. Paola Andrea Gaviria Kassama - UNIFESP 
"Nas atividades de natureza exteriormente séria esconde-se um elemento de jogo."

(Johan Huizinga, 1946) 


\section{Agradecimentos}

Agradeço primeiramente a Deus que tem prazer no bem-estar de seus servos e que, por intermédio de Nossa Senhora da Conceição Aparecida, cuja missão é passar à frente das batalhas de seus filhos, me permitiu essa conquista.

Em seguida agradeço à minha orientadora Prof. Dra. Cristina Cerri por abraçar meu tema de pesquisa, dedicando-se ao aprofundamento do mesmo para transferir a mim seu conhecimento, com toda paciência.

Aos membros da banca: Prof. Dr. Pedro Aladar Tonelli e Prof ${ }^{a}$. Dr ${ }^{a}$. Paola Andrea Gaviria Kassama por toda receptividade e atenção, bem como pelas excelentes sugestões que irrequeceram meu trabalho.

À Prof. Dra. Iole de Freitas Druck, pelas valiosas contribuições no decorrer do curso.

À minha amiga Débora, por me apresentar o programa de mestrado que concluo, conduzindo-me até o Instituto por vários dias, bem como dividindo comigo seus saberes.

Ao meu esposo Claudivan, por compreender minha dedicação aos estudos.

Ao meu amigo e radialista Fábio Teruel, por todo incentivo diário e por toda a sabedoria em usar suas palavras a fim de modificar a mentalidade de quem o ouvi, em função de realizar sonhos.

À minha mãe Nadir, por sempre me acompanhar no caminho de estudos que durante a toda vida eu quis trilhar, mas que, sem sua companhia eu jamais conseguiria dar nem se quer os primeiros passos. 



\section{RESUMO}

TEIXEIRA, R. R. (2018). Situações de conflito: uma aplicação da Teoria dos Jogos em sala de aula. (Dissertação de Mestrado). Instituto de Matemática e Estatística, Universidade de São Paulo, São Paulo.

Esta pesquisa aborda uma área da Matemática que trabalha a tomada de decisão. Trata da aplicação e análise de uma sequência de atividades para alunos do Ensino Médio de uma escola estadual da cidade de São Paulo com base em conceitos da Teoria dos Jogos. Tem como objetivos apresentar situações de dilema e jogos e promover a discussão de estratégias ótimas para solucioná-los, bem como apresentar aos alunos elementos desta teoria, tendo em vista a importância de desenvolver a habilidade de tomar decisões em situações de conflito. Design experiment foi o referencial metodológico escolhido. Inicialmente é apresentado um breve resumo da história da Teoria dos Jogos, destacando seus principais contribuidores, bem como uma explanação de seus conceitos e fundamentos, seguida de um resumo do modelo matemático. Na sequência, tem-se uma análise da relação entre o desenvolvimento da habilidade de tomar decisão em situações de conflito na formação escolar e os jogos dessa teoria; são citadas experiências de aplicações em sala de aula realizadas por alguns autores e conclusões obtidas. Em seguida, é feita uma apresentação da metodologia de pesquisa utilizada, justificando-se sua pertinência a este trabalho, bem como as ações de pesquisa de acordo com o embasamento metodológico. Em capítulos posteriores tem-se a descrição das atividades realizadas, comentários e análises. Da pesquisa pode-se concluir que foi possível mostrar aos alunos elementos da Teoria do Jogos, como aplicação da Matemática e que esta é ferramenta para modelar fenômenos que envolvem tomadas de decisão. Pode-se perceber que ocorreu a sensibilização dos alunos para situações de jogos de conflito e como a teoria lida com as mesmas.

Palavras-Chave: Teoria dos Jogos. Situações de Conflito. Experimento de Ensino. Educação Básica. 


\begin{abstract}
TEIXEIRA, R. R. (2018). Situations of conflict: an application of Game Theory in the classroom. (Thesis MA). Institute of Mathematics and Statistics, University of São Paulo, São Paulo.

This research addresses an area of mathematics that works on decision making. It deals with the application and analysis of a sequence of activities for high school students of a state school in the city of São Paulo based on concepts of Game Theory. It aims to present situations of dilemma and games and to promote the discussion of optimal strategies to solve them, as well as to present to the students elements of this theory, in view of the importance of developing the ability to make decisions in situations of conflict. The "design experiment" was chosen as methodological reference. Initially, a brief summary of the history of the Game Theory is presented, highlighting its main contributors, as well as an explanation of its concepts and fundamentals, followed by a summary of the mathematical model. In the sequence, there is an analysis of the relationship between the development of the ability to make decisions in situations of conflict in school formation and the games of this theory; experiences of classroom applications made by some authors and conclusions are cited. Then, a presentation of the methodology of research is made, justifying its relevance to this work, as well as the research actions according to the methodological basis. In later chapters there is a description of the activities carried out, comments and analysis. From the research it can be concluded that it was possible to show students the elements of the Game Theory as an application of Mathematics and that this is a tool to model phenomena involving decision making. It can be noticed that students have been sensitized to situations of conflict games and how the theory deals with them.
\end{abstract}

Keywords: Game Theory. Situations of Conflict. Teaching Experiment. Basic education. 


\section{SUMÁRIO}

INTRODUÇÃ̃

\section{CAPÍTULO 1}

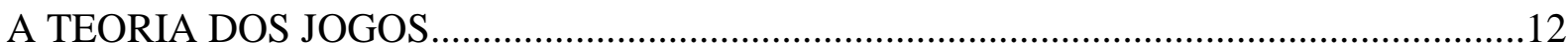

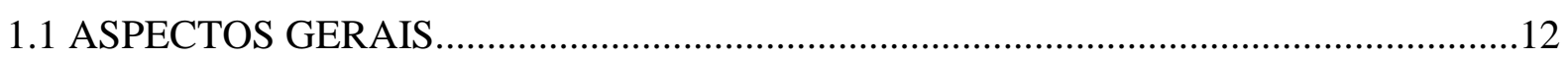

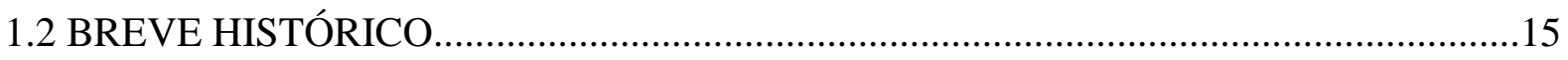

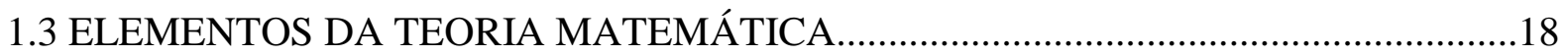

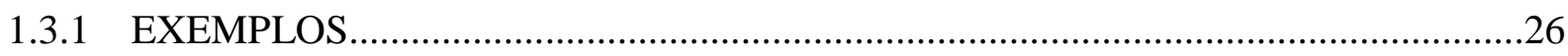

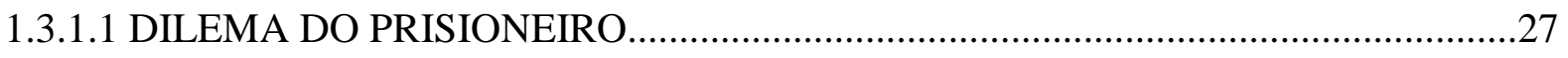

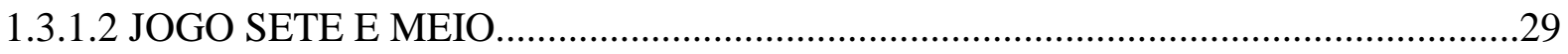

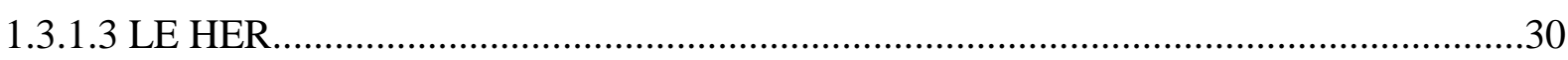

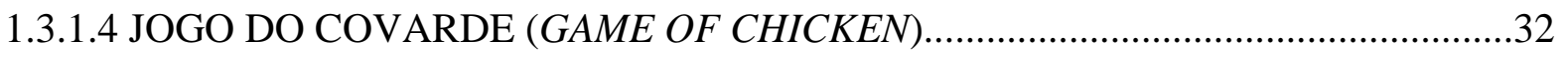

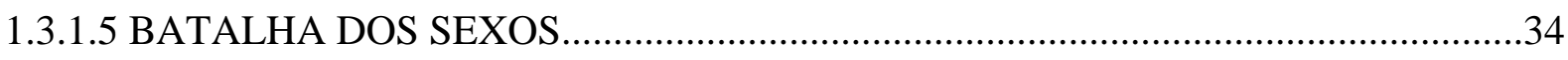

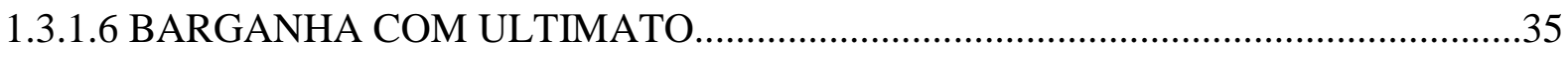

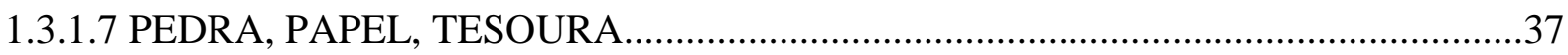

\section{CAPÍTULO 2}

A TEORIA DOS JOGOS EM SALA DE AULA.

\section{CAPÍTULO 3}

METODOLOGIA DE PESQUISA.

\section{CAPÍTULO 4}

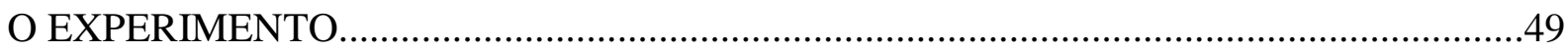

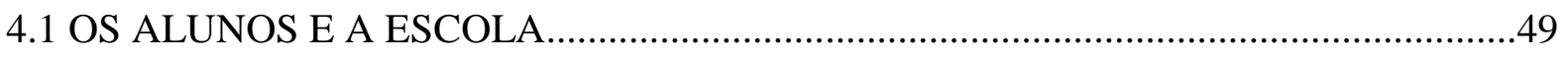

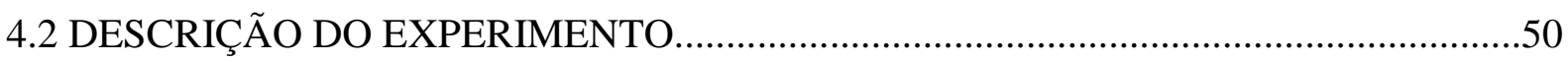

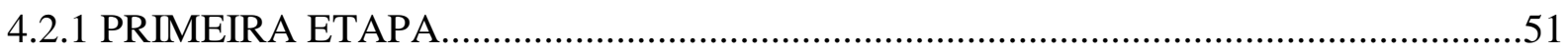

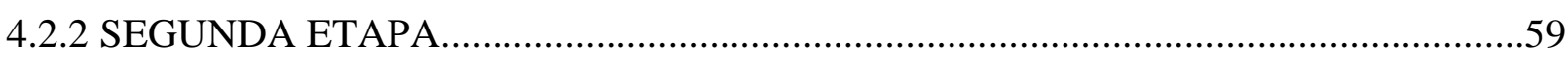

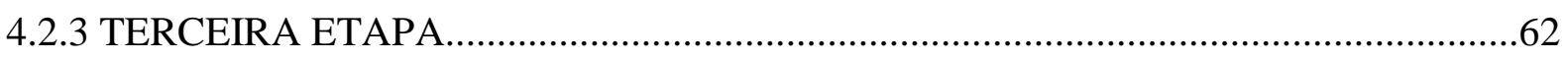

\section{CAPÍTULO 5}

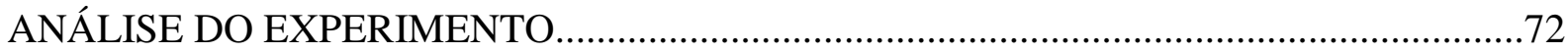

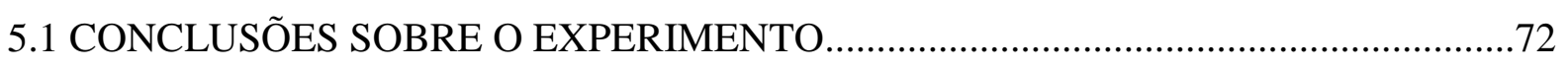

5.2 PROPOSTA DE REDESIGN DO EXPERIMENTO.....................................................75

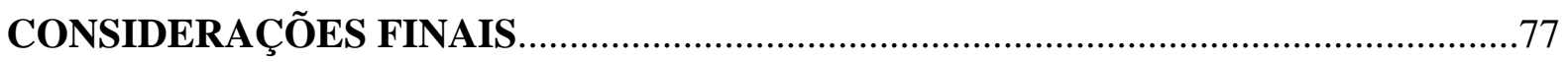

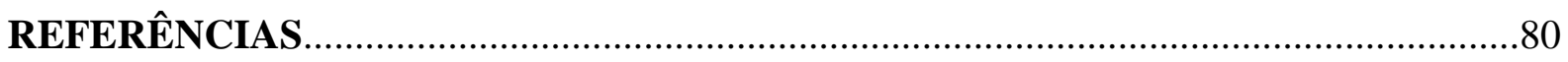




\section{INTRODUÇÃO}

"Vivendo e aprendendo a jogar. Nem sempre ganhando, Nem sempre perdendo Mas, aprendendo a jogar."

(Guilherme Arantes)

Uma das principais características da sociedade atual, marcada por profundas transformações, consiste no fato das pessoas buscarem um diferencial para sua atuação no mundo globalizado, o que demanda habilidades para enfrentar as relações sociais.

Cada indivíduo depende de outro nos diversos contextos e, sendo assim, a cooperação é vista como forma ideal de gestão das interações humanas. No entanto, situações de disputa ou de concorrência se fazem presentes em várias ocasiões, onde as escolhas individuais trazem uma causa e geram consequências.

$\mathrm{Na}$ escola, como em todos os setores da sociedade, presencia-se comportamentos e atitudes que abordam a relação entre competição e cooperação, bem como as possibilidades de se optar por uma delas, ou seja, o trabalho da tomada de decisão. Sendo assim, o ato de tomar decisões está presente nas relações arbitrárias entre pessoas, lugares, objetos e eventos fictícios; na dedução e antecipação das informações fornecidas nessas relações.

Quando se analisa o "jogo da vida”, percebe-se que os conflitos de interesse abarcam frequentemente as organizações sociais de tal forma que merecem ser equacionados. Entretanto, a tarefa de desenvolver atitudes que superem o paradigma do individualismo, que destaquem a reciprocidade das situações entre agentes, cabe então à Educação.

A Teoria dos Jogos é um ramo da Matemática utilizado para modelar fenômenos pertinentes às situações de dualidade e reciprocidade, ou seja, situações onde os envolvidos “jogam" entre si.

A pesquisadora desse trabalho interessou-se pela Teoria dos Jogos há alguns anos através de leituras sobre como esquematizar os conflitos de interesses mútuos que acontecem a todo momento nas sociedades, bem como através do conhecimento sobre a vida e obra dos principais autores dessa teoria.

Apesar de ser um campo de estudo intimamente ligado à Matemática, o escopo das áreas onde se aplica a Teoria dos Jogos é tão extenso quanto diversificado, pois tal estudo abrange qualquer contexto em que se tenha dois ou mais agentes de decisão interagindo de 
forma a competirem, ou, por que não dizer, a cooperarem simultaneamente.

Ao utilizar tais modelos, pode-se formular uma linguagem comum aos mais diferentes tipos de jogos, o que facilita o estudo e a análise dos resultados dessas interações. A Teoria dos Jogos surge como um método que permite formalizar os processos de tomada de decisão entre agentes (indivíduos, corporações ou Estados).

Neste aspecto, pode-se considerar que o legado mais importante da teoria em questão consiste no raciocínio da antecipação dos movimentos, que compreende uma ação utilizada pelas pessoas no dia a dia, em diversos tipos de situações; este contexto converge então para uma importante função da escola: educar para a vida.

A pesquisadora se interessou pela Teoria dos Jogos através do contato com obras que abordam essa teoria; a ideia de experimentá-la no campo da educação se justifica por ser esta sua área de atuação.

A motivação da pesquisadora em estudar o emprego dos pressupostos dessa teoria em sala de aula baseia-se na gama de aplicações dessa teoria em diversos campos, de modo que cada vez mais outras áreas descobrem sua funcionalidade.

Dentro do estudo da Teoria dos Jogos, o ganho para cada jogador depende das estratégias assumidas, como numa relação de causa e efeito entre as partes. Dessa forma, uma situação de jogo envolve oponentes que, de certa maneira, dependem mutuamente uns dos outros; tal relação de interdependência e de embate representa o dinamismo da vida em sociedade e sugere uma dimensão interessante a ser explorada pelas propostas de ensino.

Defender as situações de jogo como elementos úteis no processo de formação, compreende uma proposta pedagógica que propicia momentos de interação, trocas de experiências e discussões.

Seguindo nesse contexto, jogos de conflito podem compor momentos didáticos, devido à sua aproximação com situações do mundo real, uma vez que buscam responder aos interesses dos jogadores (que aprendem com suas estratégias e tomadas de decisão).

Os jogos dessa teoria apontam a relação existente entre o cooperar e o competir, o que fomenta o envolvimento por parte dos indivíduos, cujas atitudes em um jogo têm a presença constante da tomada de decisão.

A Teoria dos Jogos assume, dentro desse contexto, a abordagem de situações estratégicas, que permitem assim, desenvolver no aluno experiências de como agir mediante múltiplas possibilidades, prevendo resultados, em prol de um objetivo; isso pode ocorrer durante as jogadas e posterior às mesmas, ou seja, no momento da análise e da tomada de decisão. 
O presente trabalho apresenta a proposta de utilizar os pressupostos básicos da Teoria dos Jogos na formação escolar, com vistas a investigar sua aplicabilidade em promover um espaço para o desenvolvimento da capacidade de tomada de decisão diante de conflitos e jogos, como sendo uma importante habilidade na vida do indivíduo, objetivando expor alunos a situações de dilemas e assim promover a discussão de estratégias ótimas envolvendo cooperação ou não.

Assim sendo, este trabalho oferece elementos para responder a questão: como alunos lidam com as situações de jogos de conflito e quanto essas situações mobilizam o despertar da habilidade de tomar decisão?

O primeiro capítulo deste trabalho apresenta conceitos e fundamentos da Teoria dos Jogos, que expõem a importância e a dimensão desse tema, bem como traz uma breve revisão histórica sobre a origem e a presença dessa teoria em meio às relações que permeiam a humanidade. Além disso, há uma breve sistematização Matemática, que não se aprofunda no estudo, porém, que aborda exemplos clássicos da teoria.

No segundo capítulo, por sua vez, apresenta-se justificativas a proposta de trazer essa teoria para dentro da escola, bem como de objetivos que se pretende atingir.

No terceiro capítulo é feita uma abordagem da metodologia de pesquisa utilizada.

Um experimento realizado numa sala de aula do ensino médio de uma escola pública é relatado no capítulo quatro.

A análise do experimento realizado, em comparação aos objetivos de pesquisa é apresentada no capítulo 5, bem como um levantamento de novas possibilidades de aplicação dessa teoria na sala de aula.

O sexto e último capítulo traz as considerações finais e conclusões sobre o trabalho realizado.

$\mathrm{O}$ ato de ensinar envolve conflitos que convidam as partes envolvidas a fazerem escolhas; o de aprender conduz a estratégias que se formam para a vida. Desafie-se neste trabalho, ou por que não dizer: nessa jogada. 


\section{CAPÍTULO 1}

\section{A TEORIA DOS JOGOS}

"Na vida tudo é um jogo. Perde ou ganha... se eu não te dou você também não me dá."

(Dercy Gonçalves)

A Teoria dos Jogos pode ser definida como "uma teoria dos modelos matemáticos que estuda a escolha de decisões ótimas sobre condições de conflito" (BORTOLOSSI, GARBUGIO e SARTINI, 2017, p.10). Uma situação onde se tem um conflito ou disputa é o que se entende, dentro deste contexto, por um "jogo". Esta é uma teoria matemática que lida com opções estratégicas onde agentes, ou seja, os "jogadores" tomam decisões na tentativa de melhorar seus ganhos, dependendo das escolhas uns dos outros.

Neste capítulo apresentaremos alguns dos princípios gerais da Teoria dos Jogos, aspectos históricos, conceitos básicos da teoria matemática e alguns exemplos.

\subsection{ASPECTOS GERAIS}

A Teoria dos Jogos, segundo Fiani (2006) oferece formas de modelar uma situação de interação estratégica, bem como permite elaborar explicações para fenômenos da vida social, desde que haja interação entre indivíduos conscientes de que suas decisões individuais afetam a todos.

Tal teoria estuda as estratégias para a tomada de decisões, de pessoas, como indivíduos ou representando organizações (empresas, partidos políticos etc), em conflito com outras, independentemente de conceitos sobre certo ou errado.

Para Bortolossi, Garbugio e Sartini (2017), "A teoria dos jogos é uma teoria matemática criada para se modelar fenômenos que podem ser observados quando dois ou mais 'agentes de decisão' interagem entre si’. Ela permite comparar, por meio de esquemas, as vantagens de se optar por uma determinada decisão, tendo em vista um interesse individual e/ou coletivo. Essa teoria permite, então, a discussão de uma gama de situações de oposição presentes em contextos de diferentes áreas do conhecimento.

Essa teoria foi desenvolvida dentro do contexto econômico, objetivando a análise das 
relações entre pequenos grupos de empresas, no que refere à concorrência, bem como à necessidade de cooperação em determinados momentos. Sua aplicabilidade se alastrou por diversos fenômenos econômicos como leilões, sistemas de votação, formação de redes sociais, entre outros, cujo cenário reúne diferentes agentes que escolhem diferentes estratégias, mas que possuem objetivos comuns.

Atualmente, diferentes campos acadêmicos vêm utilizando essa teoria: ciências da natureza (estratégia evolucionária: comunicação entre os animais), ciências políticas (formação de alianças entre partidos), ciências militares (estratégias de combate e a análise dos cenários do pré e pós confronto), ciências da computação (combinação de mecanismos para obtenção de melhores configurações), filosofia (conflito entre moralidade e auto interesse), jornalismo (percepções diferentes entre os competidores: veículo jornalístico e leitor), e inteligência artificial (programação de máquinas que fazem escolhas de ações).

$\mathrm{Na}$ área biológica, por exemplo, Maynard (1982) utilizou a Teoria dos Jogos para analisar o fato de que determinadas populações de animais irracionais chegam a comportamentos complexos de cooperação mútua. Alguns biólogos também utilizam os elementos desta teoria para analisar o comportamento de competição e territorialidade.

No sistema político, o Estado é considerado o principal agente na tomada de decisão, tanto no âmbito interno quanto na política externa. Um fato que comprova a importância da Teoria dos Jogos no contexto das relações internacionais consiste na "crise dos mísseis cubanos", ocorrida em outubro de 1962: quando um Estado investe em armamentos para garantir sua segurança, os outros Estados tomam a decisão que melhor se ajusta a do adversário, ou seja, também investe em armamentos. Cabe salientar que a aplicação da Teoria dos Jogos na ciência política permite definir estratégias de voto nos comitês e na formação (ou na ruptura) de coligações parlamentares.

Um exemplo da aplicação da Teoria dos Jogos no jornalismo consiste na relação que se forma em uma cooperação entre uma fonte anônima e um repórter ou entre um veículo jornalístico e um anunciante. Os resultados desses jogos podem demonstrar, com bastante objetividade, o que normalmente só pode ser avaliado de forma subjetiva, permitindo uma melhor compreensão científica das interações estratégicas.

Pensar em uma determinada situação como se a mesma fosse um jogo permite reconhecer um conjunto de estratégias cujas combinações podem alterar a situação. Torna-se cabível mencionar que para cada situação de oposição existe um modelo de pensamento mais adequado; essas situações podem ser representadas e compreendidas como jogos.

Sendo assim, a Teoria dos Jogos estuda cenários onde existam interessados 
(jogadores) em otimizar seus resultados (perdas ou ganhos), uma vez que cada decisão depende obrigatoriamente da movimentação dos demais concorrentes. Dentro desse estudo, cabem situações de diversos contextos, onde os resultados dependem da decisão conjunta de indivíduos em lados opostos, considerando a tentativa de cada um em antecipar a escolha dos outros.

Segundo Fiani (2006) a referida teoria não fornece necessariamente uma receita pronta, uma vez que o indivíduo desenvolve sua experiência em situações de interação estratégica; nem tampouco elimina a necessidade de conhecimento e até de intuição em determinados casos, mas oferece um atalho para o entendimento sobre os fundamentos de um processo de decisão. Sendo assim, o pensamento racional presente na Teoria dos Jogos não fornece a garantia de sucesso, só dá a garantia da lógica.

Uma vez que cada jogador precisa antecipar como seus oponentes responderão à sua ação, estudiosos da Teoria dos Jogos já se referem à mesma como sendo uma ciência de estratégias, cujo foco consiste na lógica das interações entre agentes.

Através do pensamento estratégico torna-se possível analisar os dilemas e as oportunidades, sob uma perspectiva ampla, capaz de perceber o impacto de suas ações sobre os outros e vice-versa. Sendo assim, pensar estrategicamente consiste numa forma de aumentar as chances de sucesso nas situações do mundo real. Dessa forma, desenvolver o pensamento estratégico permite ao indivíduo a possibilidade de antecipar o inesperado, se comunicar melhor, bem como promover ações de planejamento para a vida. Isso implica em fazer escolhas com base na lógica de uma situação.

Fiani (2006) afirma que dentro do estudo dessa teoria, assume-se que os agentes, ou seja, os jogadores são racionais, pois supõe-se que os mesmos empregam os meios mais adequados aos objetivos que desejam. Sendo assim, para entender a lógica dos processos de decisão, a Teoria dos Jogos traz a apropriação do termo "racional" para classificar a opção mais vantajosa dentro de um jogo. Dentro desse contexto, John Von Neumann, em 1944, provou que há sempre um curso racional de ação para cada jogador; dessa forma, essa teoria visa compreender em quais circunstâncias o mais racional é competir, bem como identificar o que é preciso para que haja colaboração entre os jogadores.

A relação entre competição e cooperação apresenta jogadores que se comportam tanto como competidores individuais ou como colaboradores; isso permite questionar quais políticas devem ser adotadas (pelos gestores de um jogo) para garantir a colaboração entre os agentes. Esse dilema se faz presente em inúmeros ramos da sociedade, que apresentam uma dualidade entre o pessoal e o coletivo. 
Além disso, ao tentar entender os conflitos por meio de modelos matemáticos, a Teoria dos Jogos não abre espaço para conceitos como "bem" e "mal”, pois o foco está nas estratégias utilizadas pelos jogadores. Todavia, como existe dilema, existe jogo e, de modo geral, a tendência entre os jogadores é maximizar o ganho.

\subsection{BREVE HISTÓRICO}

Curiosamente, a ideia da Teoria dos Jogos é muito antiga, pois em vários marcos históricos pode-se fazer uma analogia a respeito da atitude que um jogador deve ter em uma disputa, em termos de estratégia e antecipação.

No século XVIII a. C., o Código de Hamurabi (conjunto de leis criadas na Mesopotâmia) era baseado na antiga Lei de Talião: "Olho por olho, dente por dente". Esta frase talhada em rocha, com escrita em caracteres cuneiformes, significa fazer ao outro o que quer que seja feito a si mesmo.

Também o general, estrategista e filósofo chinês Sun Tzu (século V a. C.) já recomendava em seu manual de guerra, denominado A Arte da Guerra ${ }^{1}$, escrito há mais de 2000 anos, a necessidade de destruir os meios de fuga dos soldados, para que os mesmos (até os insatisfeitos) não tivessem outra escolha senão lutar.

O conquistador espanhol Hernán Cortés (1485 - 1547), antes de derrubar o império asteca, destruiu os barcos que poderiam servir de meio para fuga de seus soldados, forçando os mesmos a unirem-se a ele, uma vez que estavam em território hostil e sem qualquer outra saída. Essa estratégia garantiu ao conquistador espanhol uma posição favorável.

Contudo, considera-se que James Waldegrave (1684 - 1741), embaixador inglês, foi a primeira pessoa a realizar um estudo sistemático de solução de um jogo, em 1713, fazendo uma análise do jogo de cartas chamado "Le Her". Ele propôs uma solução para uma versão deste jogo, disputada por duas pessoas, e descrito por ele em carta ao matemático francês Pierre Rémond de Montmort (1678 - 1719). O jogo foi estudado por Montmort e Nicolas Bernoulli (1687 - 1759) e os resultados publicados em 1713 onde consta-se a prova de que existe uma solução para este jogo por estratégia mista.

Em 1838, Antoine Augustin Cournot (1801 - 1877) publicou o livro Recherches sur les Principes Mathématiques de La Théorie dês Richesse ${ }^{2}$, onde apresentou um modelo de competição entre duas empresas pela produção de bens. Esse modelo econômico descrito por

1 TZU, S. A Arte da Guerra, São Paulo: Record, 2006.

2 Investigações sobre os Princípios Matemáticos da Teoria das Riquezas 
Cournot, é um caso especial de duopólio, onde as empresas competem de acordo com a quantidade produzida pelos seus concorrentes, existindo uma grande interdependência nas decisões dos agentes. Cournot foi pioneiro ao apresentar uma situação de economia como sendo um jogo.

Em 1913, Ernst Friedrich Ferdinand Zermelo (1871 - 1953), filósofo e matemático alemão, publicou o primeiro teorema matemático da Teoria dos Jogos, que afirma que em cada etapa de um jogo de xadrez, pelo menos um dos jogadores tem uma estratégia em mão que lhe dará a vitória ou conduzirá o jogo ao empate.

Felix Eduord Justin Emile Borel (1871 - 1956), matemático francês, contribuiu para a Teoria dos Jogos, quando, por volta de 1920, publicou artigos sobre "jogos de soma zero", com dois jogadores, formulando matematicamente, pela primeira vez, esse tipo de jogo.

Contudo, a Teoria dos Jogos ainda não existia como um campo unificado até o final dos anos 20. Até que o matemático húngaro de origem judaica John Von Neumann (1903 1957), naturalizado estadunidense e membro do Instituto de Estudos Avançados de Princeton, mudou este cenário. Em 1928, utilizando Topologia e Análise, apresentou em um artigo a prova que existe solução para um jogo em que se leva em consideração a distribuição probabilística sobre todas as estratégias, isto é, “demonstrou que existe solução em 'estratégias mistas' de um jogo finito de soma zero com dois jogadores e um número qualquer de estratégias puras" (BORTOLOSSI; GARBUGI e SARTINE, 2017, p.7).

Em 1938, Von Neumann conheceu em Princeton, Oskar Morgenstern (1902 - 1977), economista austríaco, criando com ele o elo entre teoria dos jogos e teoria econômica. Segundo Bortolossi, Garbugio e Santini (2017), um marco na teoria dos jogos ocorreu com a publicação, em 1944, do livro The Theory of Games and Economic Behavior ${ }^{3}$. Nesta obra foram demostradas várias aplicações da Teoria dos Jogos em economia: situações em que o resultado dependia não só da estratégia própria de um agente e das condições de mercado, mas também das estratégias escolhidas por outros agentes que possivelmente tinham estratégias diferentes ou objetivos comuns. A obra de Neumann e Morgenstern foi de grande importância para a matemática aplicada, bem como considerada um marco para a teoria das decisões econômicas.

A Teoria dos Jogos recebeu uma contribuição muito importante em 1950, feita por Jonh Forbes Nash (1928 - 2015), matemático norte-americano da Universidade de Princeton. Ele estudou jogos ditos cooperativos, onde existe a possibilidade dos participantes entrarem

3 A Teoria dos Jogos e o comportamento humano 
em acordo para obterem uma solução; e não cooperativos, onde não são feitos acordos entre os participantes. Em sua tese de doutorado, de 1949, intitulada Non-cooperative Games ${ }^{4}$, Nash definiu o conceito de "ponto de equilíbrio" de um jogo (hoje conhecido como “equilibrio de Nash") e provou sua existência para jogos não cooperativos. De forma sucinta, o equilíbrio de um jogo é um ponto onde cada jogador não tem incentivo para mudar sua estratégia se os demais jogadores não o fizerem.

O economista húngaro John Charles Harsanyi (1920 - 2000) fez contribuições importantes para o uso da Teoria dos Jogos e raciocínio econômico aplicados em filosofia e política.

O matemático e economista alemão Reinhard Selten (1930 - 2016) também contribuiu de forma significativa para o desenvolvimento da Teoria do Jogos, apresentando ferramentas teóricas que possibilitaram uma maior variedade de modelos.

Em 1994, John Nash, John Harsanyi e Reinhard Selten receberam o prêmio Nobel de Economia pelas contribuições ao desenvolvimento da Teoria do Jogos e suas aplicações na Economia.

John Nash teve sua vida retratada no livro Uma Mente Brilhante, de Sylvia Nasar, publicado em 1998. A autora retratou sua conturbada trajetória à procura de uma ideia original, que consistiu numa teoria revolucionária com aplicação à economia moderna. A vida e a obra de Nash também foram retratadas no cinema em 2001, com base na obra de Nasar.

O economista Thomas C. Schelling, professor da Universidade de Maryland, e o matemático Robert J. Aumann, professor da Universidade Hebraica de Jerusalém, ganharam o prêmio Nobel de economia em 2005, trazendo aplicações da Teoria dos Jogos no campo das relações internacionais.

Cabe mencionar que, um dos mais importantes trabalhos de Schelling foi o livro intitulado The Strategy of Conflict ${ }^{5}$, publicado em 1960, que possibilitou aplicar a Teoria dos Jogos a dois dos problemas que mais atormentavam o mundo no período em que seu trabalho foi publicado: a segurança global e a corrida armamentista (Folha de São Paulo, 11 de out. 2005).

Devido às descobertas e contribuições dos estudiosos citados nesta seção, a Teoria dos Jogos pode ser formulada e desenvolvida para além dos domínios matemáticos e econômicos.

4 Jogos Não Cooperativos

5 A Estratégia do Conflito 


\subsection{ELEMENTOS DA TEORIA MATEMÁTICA}

Nesta seção serão apresentados alguns elementos da Teoria dos Jogos, relevantes para este trabalho. Este é um assunto é bastante complexo e o objetivo neste trabalho não é abordar o assunto de forma profunda, mas apresentar apenas noções básicas e alguns tipos de jogos. Para mais detalhes da teoria matemática o leitor pode consultar, por exemplo, o texto de Bortolossi, Garbugio,e Sartini (2017).

Neste contexto, um jogo é qualquer situação que envolva duas ou mais entidades (ou agentes), que podem ser pessoas, empresas ou Estados, onde cada uma toma decisões que interferem nas decisões tomadas pela(s) outra(s). Então um jogador é um agente que toma decisões em um jogo. Assume-se que todo jogador tem interesse em participar do jogo, buscando algum ganho que, no entanto, pode ser para ele satisfatório ou não.

Como modelo matemático a Teoria dos Jogos tem alguns pressupostos. Considera-se os jogadores como racionais, ou seja, como agentes que pretendem maximizar seus ganhos. Admite-se que cada jogador conheça toda a estrutura de um jogo.

Como exemplo de um jogo tem-se a seguinte situação hipotética denominada Batalha dos Países: dois países $A$ e $B$ exportam produtos agropecuários, um para o outro, de modo que tanto $A$ quanto $B$ possuem apenas duas opções: ou adotam tarifas baixas, em relação ao mercado de exportação, ou adotam tarifas altas (não sendo possível recusar-se a exportar). Então, a opção adotada pelo país $A$ interfere na opção adotada pelo país $B$ e vice e versa. Neste exemplo os jogadores desejam escolher específicas opções que otimize seus ganhos (no caso, financeiros).

Pode-se classificar os jogos em cooperativos e não cooperativos. Um jogo é dito cooperativo quando os jogadores colaboraram e fazem acordos para obter um melhor ganho para todos. Por exemplo, quando duas empresas concorrentes buscam uma parceria (ou seja, uma cooperação) entre si para lançar um novo produto no mercado, lançando assim, um mesmo produto. Se não buscam essa parceria, ambas têm um custo maior para produzir individualmente esse produto, bem como enfrentam a concorrência mútua, o que dificultaria o lucro de ambas.

Um jogo é dito não cooperativo quando cada um dos jogadores busca estratégias para obter o melhor ganho para si. A Batalha dos Países consiste em um exemplo de jogo não cooperativo. Outro exemplo é o popular jogo Par ou Ímpar: dois jogadores desejam ganhar uma disputa onde o resultado da soma é um número par ou ímpar: um deles escolhe resultado par e o outro escolhe resultado ímpar e mostram, simultaneamente, um valor entre zero a 
cinco; se a soma dos valores for um número par, o jogador que escolheu resultado par ganha; se for ímpar, quem ganha é o jogador que escolheu resultado ímpar.

Em um jogo cooperativo os participantes podem negociar contratos de cumprimento obrigatório entre si, o que lhes permite planejar estratégias em conjunto. Em um jogo não cooperativos não são previstas negociações ou acordos entre os jogadores; mesmo havendo uma combinação prévia, não há mecanismos para obrigar o cumprimento do acordo feito entre os participantes.

$\mathrm{Na}$ Teoria dos Jogos são estudados os jogos de jogada única, ou seja, aqueles que admitem apenas uma ação para cada jogador, como também os jogos com jogadas sucessivas. Os exemplos citados, Batalha dos Países e Par ou Ímpar, são jogos de jogada única, enquanto que o Jogo de Xadrez consiste, obviamente, em um exemplo de jogo com sucessivas jogadas.

Neste trabalho serão abordados elementos da teoria relacionados aos jogos do tipo não cooperativos, entre dois jogadores e de jogada única.

Toda decisão a ser tomada por um jogador, deve levar em consideração as possíveis decisões do(s) oponente(s). Nesse contexto, considera-se as estratégias como sendo escolhas disponíveis para cada um dos jogadores. Fiani (2004), afirma que a estratégia assumida por um jogador compreende uma ação planejada que especifica o que o jogador pode fazer, com vistas a melhorar seu ganho. Por exemplo, as estratégias disponíveis para cada jogador no jogo Batalha dos Países são: adotar tarifas altas e adotar tarifas baixas.

Sendo assim, em um jogo cada jogador possui um conjunto de opções, denominadas estratégias puras. Uma combinação das estratégias assumidas pelos jogadores, ou seja, uma combinação de escolhas (uma de cada jogador) recebe o nome de perfil de estratégia pura.

Especificamente, num jogo temos o conjunto finito de jogadores, denotado por $G=\left\{g_{1}, g_{2}, \ldots g_{n}\right\}$, sendo $n \geq 2$ (há sempre dois ou mais jogadores).

E cada jogador $g_{i}$ de $G, i=1, \ldots, n$, possui um conjunto de estratégias puras: $S_{i}=$ $\left\{s_{i 1}, s_{i 2}, \ldots s_{i m_{i}}\right\}$, com $m_{i} \geq 2$ (há sempre duas ou mais estratégias para cada jogador).

O conjunto de todos os perfis de estratégias puras de todos os jogadores é o produto cartesiano $S=S_{1} \times S_{2} \times \ldots \times S_{n}$

Então o vetors $=\left(s_{1 j_{1}}, s_{2 j_{2}}, \ldots, s_{n j_{n}}\right)$ é um perfil de estratégias puras, onde $s_{i j_{i}}$, é uma estratégia pura do jogador $g_{i}$.

Tomando como exemplo o jogo Batalha dos Países, os jogadores são os países $A$ e $B$, ou seja, $G=\left\{g_{1}, g_{2}\right\}=\{$ país A, país B $\}$.

O conjunto de estratégias puras para o país $A$ (jogador $g_{1,}$ ) é $S_{1}=\left\{s_{11}, s_{12}\right\}=\{$ Tarifas 
Altas, Tarifas Baixas $\}$, assim como $S_{2}=\left\{s_{21}, s_{22}\right\}=$ \{Tarifas Altas, Tarifas Baixas $\}$ é o conjunto de estratégias puras para o país $B$ (jogador $g_{2}$ ).

Logo, $S=S_{1} \times S_{2}=\{($ Tarifas Altas, Tarifas Altas), (Tarifas Altas, Tarifas Baixas), (Tarifas Baixas, Tarifas Altas), (Tarifas Baixas, Tarifas Baixas)\} é o conjunto de todos os perfis de estratégias puras de $g_{1}$ e $g_{2}$. Assim, por exemplo, $\mathrm{s}=\left(s_{12}, s_{21}\right)=($ Tarifas Baixas, Tarifas Altas) é um perfil de estratégia pura que representa o país $A$ adotando tarifas baixas e $B$ adotando tarifas altas.

Um conceito importante é o da função utilidade, que consiste numa função definida para cada jogador, que atribui a um perfil de estratégias puras um número real que representa o ganho do jogador. Este valor é também denominado de payoff. Uma possível tradução para o termo payoff consiste em "ganho" ou "pagamento".

Define-se a função utilidade do jogador $g_{\mathrm{i}} \in G$ por $u_{i}: S \rightarrow \mathbb{R}, s \rightarrow u_{i}(s)$ sendo $i$ $=1, \ldots, n$, onde $u_{\mathrm{i}}(s)$ é o payoff (ganho ou pagamento) do jogador $g_{i}$.

Voltando ao jogo Batalha dos Países, pode-se definir a função utilidade de cada jogador (país) da seguinte forma: se ambos os países adotarem tarifas baixas, supõe-se que os mesmos podem não ter lucro e convém atribuir o número $1 / 2$ a cada um deles (referente a um "meio ganho"); se ambos adotarem tarifas altas, supõe-se que ambos podem não ter prejuízo e convém atribuir o número 0 a cada um deles (pois não terão ganho); se um deles adotar tarifas altas e o outro adotar tarifas baixas, supõe-se que o primeiro terá lucro e que o outro terá prejuízo, podendo-se atribuir respectivamente os números 1 e -1 .

Atribui-se, então, aos perfis de estratégias desse jogo, os seguintes ganhos para o país $A$ (jogador $\left.g_{1}\right)$ :

$$
\begin{aligned}
& u_{1}:\left(\mathrm{s}_{11}, \mathrm{~s}_{21}\right)=(\text { Tarifas Baixas, Tarifas Baixas }) \rightarrow 1 / 2 \\
& u_{1}:\left(\mathrm{s}_{11}, \mathrm{~s}_{22}\right)=(\text { Tarifas Baixas, Tarifas Altas }) \rightarrow-1 \\
& u_{1}:\left(\mathrm{s}_{12}, \mathrm{~s}_{21}\right)=(\text { Tarifas Altas, Tarifas Baixas }) \rightarrow 1 \\
& u_{1}:\left(\mathrm{s}_{22}, \mathrm{~s}_{12}\right)=(\text { Tarifa Altas }, \text { Tarifa Altas }) \rightarrow 0 .
\end{aligned}
$$

Da mesma forma, se representa a função utilidade do jogador $\mathrm{g}_{2}$ (país B).

$$
\begin{aligned}
& u_{2}:\left(\mathrm{s}_{11}, \mathrm{~s}_{21}\right)=(\text { Tarifas Baixas, Tarifas Baixas }) \rightarrow 1 / 2 \\
& u_{2}:\left(\mathrm{s}_{11}, \mathrm{~s}_{22}\right)=(\text { Tarifas Baixas, Tarifas Altas }) \rightarrow 1 \\
& u_{2}:\left(\mathrm{s}_{12}, \mathrm{~s}_{21}\right)=(\text { Tarifas Altas, Tarifas Baixas }) \rightarrow-1 \\
& u_{2}:\left(\mathrm{s}_{22}, \mathrm{~s}_{12}\right)=(\text { Tarifa Altas }, \text { Tarifa Altas }) \rightarrow 0 .
\end{aligned}
$$

No jogo Par ou Ímpar, o conjunto das estratégias puras de cada jogador é $S_{\mathrm{i}}=\{$ Par, Ímpar\}, para $i=1,2$. Portanto, o conjunto formado por todos os perfis de estratégias puras dos dois jogadores é $S=\{($ Par, Par), (Par, Ímpar), (Ímpar, Par), (Ímpar, Ímpar) $\}$. 
Para o jogo Par ou Ímpar, atribui-se valor 1 para o vencedor e valor -1 para o perdedor. Então, supondo que o jogador I escolha resultado par e que o jogador II escolha resultado ímpar, a função utilidade do jogador I $\left(g_{1}\right)$ é assim definida:

$$
\begin{aligned}
& u_{1}:\left(\mathrm{s}_{11}, \mathrm{~s}_{21}\right)=(\text { par }, \text { par }) \rightarrow 1 \\
& u_{1}:\left(\mathrm{s}_{11}, \mathrm{~s}_{22}\right)=(\text { par }, \text { ímpar }) \rightarrow-1 \\
& \left.u_{1}:\left(\mathrm{s}_{12}, \mathrm{~s}_{21}\right)=\text { (ímpar, par }\right) \rightarrow-1 \\
& \left.u_{1}:\left(\mathrm{s}_{12}, \mathrm{~s}_{22}\right)=\text { (ímpar, ímpar }\right) \rightarrow 1 .
\end{aligned}
$$

Define-se, analogamente, a função utilidade do jogador II $\left(\mathrm{g}_{2}\right)$.

Uma forma de representar os perfis de estratégias e os ganhos (payoff) utiliza-se uma matriz, chamada Matriz Payoff: Portanto, uma Matriz Payoff é composta por todos dos perfis de estratégias puras do jogo e os respectivos valores da função utilidade, representados em

\begin{tabular}{|c|c|c|c|}
\hline & & \multicolumn{2}{|c|}{ PAÍS $B$} \\
\hline & & Tarifas Baixas & Tarifas Altas \\
\hline \multirow{2}{*}{ PAIS $A$} & Tarifas Baixas & $(1 / 2,1 / 2)$ & $(-1,1)$ \\
\hline & Tarifas Altas & $(1,-1)$ & $(0,0)$ \\
\hline
\end{tabular}
pares ordenados.

Para exemplificar, a seguir mostramos as Matrizes Payoff dos jogos Batalha dos Países e Par ou Ímpar:

\begin{tabular}{|c|c|c|c|}
\cline { 3 - 4 } \multicolumn{2}{c|}{} & \multicolumn{2}{c|}{ JOGADOR II } \\
\cline { 3 - 4 } \multicolumn{2}{c|}{} & PAR & ÍMPAR \\
\hline \multirow{3}{*}{ JOGADOR I } & PAR & $(1,-1)$ & $(-1,1)$ \\
\cline { 2 - 4 } & ÍMPAR & $(-1,1)$ & $(1,-1)$ \\
\hline
\end{tabular}

Os jogos não cooperativos se dividirem entre jogos de soma zero e jogos de soma não zero. Nos jogos de soma zero a soma dos ganhos de cada jogador para um perfir de estratégias puras é zero, isto é, em um jogo com $n$ jogadores $\left(u_{1}+u_{2}+\ldots+u_{\mathrm{n}}\right)(\mathrm{s})=0$. Os jogos de soma não zero, por sua vez, admitem a possibilidade de resultado favorável para mais de um jogador; a soma dos payoffs dos jogadores é diferente de zero.

O jogo de Par ou Ímpar só admite um ganhador e pode então ser tomado como exemplo de jogo de soma zero. O jogo Batalha dos Países consiste em um exemplo de jogo de soma não zero, uma vez que há a possibilidade de ambos os jogadores terminarem com 
alguma vantagem, ou seja, quando os dois países adotam tarifas baixas.

Define-se o conceito de estratégia dominante para um jogador, quando a estratégia assumida por ele lhe permite um melhor ganho no jogo, qualquer que seja a estratégia escolhida pelo(s) outro(s) jogador(es).

Para cada jogador $g_{i}, \operatorname{com} i=1, \ldots, n$, denota-se por

$s_{-i}=\left(s_{1 j_{1}}, s_{2 j_{2}}, \ldots, s_{(i-1) j_{i-1}}, s_{(i+1) j_{i+1}}, \ldots, s_{n j_{n}}\right)$

as estratégias puras de todos os jogadores, menos do jogador $g_{\mathrm{i}}$.

E assim um perfil de estratégias puras de todos os jogadores, inclusive do jogador $g_{i}$ pode ser denotado por

$$
s=\left(s_{i j_{i}}, s_{-i}\right)=\left(s_{1 j_{1}}, s_{2 j_{2}}, \ldots, s_{(i-1) j_{i-1}}, s_{i j_{i}}, s_{(i+1) j_{i+1}}, \ldots, s_{n j_{n}}\right)
$$

Compara-se os payoff para determinar qual a estratégia dominante. Assim uma estratégia pura $s_{i k}$ para o jogador $g_{i}$ é dominante em relação a outra estratégia $s_{i k}$, se para todo $s_{-i}$ tem-se $u_{i}\left(s_{i k}, s_{-i}\right) \geq u_{i}\left(s_{i k^{\prime}}, s_{-i}\right)$. Ou seja, a estratégia pura $s_{i k}$ traz o maior ganho para o jogador $g_{i}$ do que qualquer outra estratégia $s_{i k}$.

No jogo Batalha dos Países, por exemplo, se o país $A$ adota Tarifas Altas e o país $B$ adota Tarifas Baixas, $A$ ganha; se o país $A$ adota Tarifas Altas e $B$ também adota Tarifas Altas, ambos não ganham, mas $A$ garante que $B$ também não ganhe. Sendo assim, Tarifas Altas é uma estratégia dominante para $A$. Isso pode ser analisado da seguinte forma:

$u_{1}\left(s_{12}, s_{21}\right)=u_{1}$ (Tarifas Altas, Tarifas Baixas) $=1>u_{1}\left(s_{11}, s_{21}\right)=u_{1}$ (Tarifa Baixa, Tarifa Baixa) $=1 / 2$.

$$
\left.u_{1}\left(s_{12}, s_{22}\right)=u_{1} \text { (Tarifas Altas, Tarifas Altas }\right)=0 .>u_{1}\left(s_{11}, s_{22}\right)=u_{1} \text { (Tarifa Baixa, }
$$

Tarifa Alta) $=-1$.

A estratégia pura dominante obtida em todos os casos é $s_{12}$. Analogamente, Tarifas Altas ( $s_{22}$ )é uma estratégia dominante para o país $B$.

$u_{2}\left(s_{12}, s_{22}\right)=u_{2}$ (Tarifas Altas, Tarifas Altas $)=0 .>u_{2}\left(s_{12}, s_{21}\right)=u_{2}$ (Tarifa Alta, Tarifa Baixa) $=-1$.

$$
u_{2}\left(s_{11}, s_{22}\right)=u_{2} \text { (Tarifas Baixas, Tarifas Altas) }=1 .>u_{2}\left(s_{11}, s_{21}\right)=u_{2} \text { (Tarifa Baixa, }
$$

Tarifa Baixa) $=1 / 2$.

Com esta escolha, um não tem nada a perder, independentemente da escolha do outro.

Deve-se observar que nem todo jogo admite uma estratégia dominante para todos os jogadores; há jogos em que não há estratégia dominante para nenhum jogador. Por exemplo, no jogo Par ou Impar tem-se:

$$
u_{1}\left(s_{11}, s_{21}\right)=u_{1}(\text { Par }, \text { Par })=1>u_{1}\left(s_{12}, s_{21}\right)=u_{1}(\text { Impar, Par })=-1 .
$$




$$
\begin{aligned}
& u_{1}\left(s_{11}, s_{22}\right)=u_{1}(\text { Par, Impar })=-1<u_{1}\left(s_{12}, s_{22}\right)=u_{1}(\text { Impar, Impar })=1 . \\
& \left.u_{2}\left(s_{11}, s_{21}\right)=u_{2} \text { (Par, Par }\right)=-1<u_{2}\left(s_{12}, s_{21}\right)=u_{2}(\text { Impar, Par })=1 . \\
& \left.u_{2}\left(s_{11}, s_{22}\right)=u_{2} \text { (Par, Impar }\right)=1>u_{2}\left(s_{12}, s_{22}\right)=u_{2}(\text { Impar, Impar })=-1 .
\end{aligned}
$$

Define-se um dos mais importantes conceitos presentes no estudo da Teoria dos Jogos: Equilibrio de Nash. Este consiste em um perfil de estratégias de modo que não seja mais vantajoso a nenhum dos jogadores mudar a escolha se o outro não mudar também. $\mathrm{O}$ ponto de Equilíbrio de Nash consiste na combinação das estratégias de todos jogadores, em que nenhum deles se arrepende da escolha assumida, perante as escolhas do(s) outro(s).

Um perfil de estratégias $s^{*}=\left(s_{1}^{*}, \ldots, s_{(i-1)}^{*}, s_{i}^{*}, s_{(i+1)}^{*}, \ldots, s_{n}^{*}\right) \in S$ é um Equilíbrio de Nash (em estratégias puras) se

$$
u_{i}\left(s_{i}^{*}, s_{-i}^{*}\right) \geq u_{i}\left(s_{i j_{i}}, s_{-i}^{*}\right)
$$

para todo $i=1, \ldots, n$ e para todo $j_{\mathrm{i}}=1, \ldots, m_{i}, \operatorname{com} m_{i} \geq 2$.

Voltando ao jogo "Batalha dos Países", o perfil $\left(s_{12}, s_{22}\right)=$ (Tarifas Altas , Tarifas Altas) é um Equilíbrio de Nash, pois nenhum dos países aumenta seu ganho mudando de estratégia sozinho: quando o país $A$ adota Tarifas Altas e o país $B$ adota Tarifas Altas, se $A$ mudar de estratégia e $B$ não, ou seja, se $A$ adotar Tarifas Baixas e $B$ permanecer com Tarifas Altas, $A$ perde; quando o país $A$ adota Tarifas Altas e o país $B$ adota Tarifas Altas, se $B$ mudar de estratégia e $A$ não, ou seja, se $A$ permanecer com Tarifas Altas e $B$ adotar Tarifas Baixas, $B$ perde. Todos os perfis de melhor estratégia a ser tomada, mediante a estratégia fixada, demonstrados acima, são iguais a $\left(\mathrm{s}_{12}, \mathrm{~s}_{22}\right)$. Esse jogo possui Equilíbrio de Nash em Estratégias Puras, pois há um perfil de estratégias puras onde cada um dos agentes não tem interesse em trocar de estratégia sozinho.

Porém, existem jogos onde isso não ocorre. Por exemplo, no jogo "Par ou Ímpar, em todos os perfis de estratégias puras, cada jogador tem vantagem em mudar de estratégia sozinho. Se o jogador I adota a estratégia Par e o jogador II adota a estratégia Ímpar, se I mudar e II não, ou seja, se I adotar Ímpar e II adotar Ímpar, I ganha. Assim se observa em todos os outros perfis, que mudar sozinho de estratégia é vantajoso. Nesse caso, verifica-se a não existência de Equilíbrio de Nash em Estratégias Puras.

Para se abordar tais tipos de jogos se faz um outro tipo de tratamento. Um jogo pode também ser tratado do ponto de vista probabilístico. Neste caso cada jogador escolhe uma distribuição de probabilidade sobre suas estratégias puras. Uma estratégia mista para um jogador consiste em uma distribuição de probabilidade sobre o conjunto das estratégias puras desse jogador, de modo que a soma das probabilidades seja igual à 1. 
Denota-se por $p_{i}=\left(p_{i 1}, p_{i 2}, p_{i 3}, \ldots, p_{i m_{i}}\right)$ um perfil de estratégias mistas do jogador $g_{i}, \operatorname{com} p_{i 1} \geq 0, p_{i 2} \geq 0, \ldots, p_{i m_{i}} \geq 0$ e $\sum_{k=1}^{m_{i}} p_{i k}=1$, sendo $m_{i} \geq 2$ e $k \geq 2$.

Ou seja, cada $p_{i}$ é um elemento do conjunto

$\Delta_{m_{i}}=\left\{\left(x_{1}, x_{2}, \ldots, x_{m_{i}}\right), x_{1} \geq 0, x_{2} \geq 0, \ldots, x_{m i} \geq 0, \sum_{k=1}^{m_{i}} x_{k}=1\right\}$

chamado de conjunto das estratégias mistas do jogador $g_{i}$.

O conjunto de todos os perfis de estratégias mistas dos jogadores é o produto cartesiano

$$
\Delta=\Delta_{m_{1}} \times \Delta_{m_{2}} \times \ldots \times \Delta_{m_{n}}
$$

Então um perfil de estratégias mistas é um vetor $\boldsymbol{p}=\left(p_{1}, p_{2}, \ldots, p_{n}\right)$ do conjunto $\Delta$.

No caso do jogo Par ou Ímpar, como é um jogo com duas estratégias puras apenas o conjunto de estratégias mistas de cada jogador é do tipo:

$$
\{(x, 1-x), 0 \leq x \leq 1,\},
$$

onde $x$ é a probabilidade da estratégia "Par" e $1-x$ a probabilidade da "Ímpar". Portanto,

$$
\Delta=\Delta_{1} \times \Delta_{2}=\left\{\left(\left(x_{1}, 1-x_{1}\right),\left(x_{2}, 1-x_{2}\right)\right) 0 \leq x_{1} \leq 1,0 \leq x_{2} \leq 1\right\}
$$

Por exemplo, no jogo Par ou Impar, o jogador $g_{1}$ pode escolher a distribuição de probabilidade $p_{1}=(1 / 4,3 / 4)$, isto é, a probabilidade de escolher par é $1 / 4$, e portanto de escolher ímpar é $3 / 4$. O jogador $g_{2}$ pode escolher a distribuição de probabilidade $p_{2}=(1 / 3,2 / 3)$, ou seja, a probabilidade de escolher par é $1 / 3$. Portanto, neste caso, um perfil de estratégias mistas possível é $\boldsymbol{p}=((1 / 4,3 / 4),(1 / 3,2 / 3))$. Nota-se que, quando a probabilidade de um dos jogadores escolher par é 1 e a probabilidade do outro jogador escolher par também é 1, tem-se um perfil de estratégia mista que também corresponde a um perfil de estratégia pura, ou seja, $\boldsymbol{p}=((1,0)$, $(1,0))$ corresponde ao perfil de estratégia pura $s=($ Par, Par).

Para cada perfil de estratégias mistas associa-se também um payoff para cada jogador, obtido por uma média ponderada dos payoff das estratégias puras.

Neste caso, define-se a função utilidade $U_{i}: \Delta \rightarrow \mathbb{R}$ do jogador $g_{i} \in G$ da seguinte forma: se

$$
\begin{gathered}
p=\left(p_{1}, p_{2}, \ldots, p_{n}\right)= \\
\left(\left(p_{11}, p_{12}, \ldots, p_{1 m_{1}}\right),\left(p_{21}, p_{22}, \ldots, p_{2 m_{2}}\right), \ldots,\left(p_{n 1}, p_{n 2}, \ldots, p_{n m_{n}}\right)\right)
\end{gathered}
$$

então

$$
U_{i}(p)=\sum_{j_{1}}^{m_{1}} \sum_{j_{2}}^{m_{2}} \ldots \sum_{j_{n}}^{m_{n}} p_{1 j_{1}} \cdot p_{2 j_{2}} \ldots p_{n j_{n}} \cdot u_{i}\left(s_{1 j_{1}}, s_{2 j_{2}}, \ldots s_{n j_{n}}\right)
$$


Por exemplo, no jogo Par ou Ímpar, considerando os ganhos dos jogadores $g_{1}$ e $g_{2}$, o perfil de estratégias mistas $p_{1}=\left(x_{1}, 1-x_{1}\right)$ do jogador $g_{1}$ e o perfil de estratégias mistas $p_{2}=$ $\left(x_{2}, 1-x_{2}\right)$ do jogador $g_{2}$, tem-se:

$$
\begin{aligned}
U_{1}(p)=U_{1} & \left(\left(x_{1}, 1-x_{1}\right),\left(x_{2}, 1-x_{2}\right)\right)=x_{1} \cdot x_{2} \cdot u_{1}(\text { par, par })+x_{1} \cdot\left(1-x_{2}\right) \cdot u_{1}(\text { par }, \text { impar }) \\
& +\left(1-x_{1}\right) \cdot x_{2} \cdot u_{1}(\text { impar, par })+\left(1-x_{1}\right) \cdot\left(1-x_{2}\right) \cdot u_{1}(\text { impar }, \text { impar }) \\
& x_{1} x_{2}(+1)+x_{1}\left(1-x_{2}\right)(-1)+\left(1-x_{1}\right) x_{2}(-1)+\left(1-x_{1}\right)\left(1-x_{2}\right)(+1) \\
& x_{1} x_{2}-x_{1}+x_{1} x_{2}-x_{1}+x_{1} x_{2}+1-x_{2}-x_{1}+x_{1} x_{2}=4 x_{1} x_{2}-2 x_{1}-2 x_{2}+1 \\
& U_{2}(p)=U_{2}\left(\left(x_{1}, 1-x_{1}\right),\left(x_{2}, 1-x_{2}\right)\right)=-\left(4 x_{1} x_{2}-2 x_{1}-2 x_{2}+1\right)
\end{aligned}
$$

Por exemplo, se $\boldsymbol{p}=((1 / 4,3 / 4),(1 / 3,2 / 3))$ então $U_{1}(\boldsymbol{p})=1 / 6$ e $U_{2}(\boldsymbol{p})=-1 / 6$

Define-se, então, o conceito de equilíbrio de Nash no caso de estratégias mistas. Assim como antes são uteis algumas notações.

Para cada $i=1, \ldots, n, \quad p_{-i}=\left(p_{1}, p_{2}, \ldots, p_{i-1}, p_{i+1}, \ldots, p_{n}\right)$ denota o perfil de estratégias mistas de cada jogador, menos do jogador $g_{i}$. E então o perfil de em estratégias mistas de todos os jogadores, inclusive de $g_{i}$ é $p=\left(p_{i}, p_{-i}\right)=\left(p_{1}, p_{2}, \ldots, p_{i-1}, p_{i}, p_{i+1}, \ldots, p_{n}\right)$.

Quando uma escolha de distribuição de probabilidade traz um melhor ganho, independentemente das escolhas de distribuições de probabilidade do(s) outro(s) jogador(es), define-se o conceito de estratégia dominante em estratégias mistas. $\mathrm{O}$ conceito de dominância também é estendido. Se $U_{i}\left(p_{i}{ }^{\prime}, \boldsymbol{p}_{-i}\right) \geq U_{i}\left(p_{i}, \boldsymbol{p}_{-i}\right)$, então se diz que $p_{i}{ }^{\prime} \in \Delta_{m i}$ é uma estratégia mista que domina qualquer estratégia mista $p_{i} \in \Delta_{\mathrm{mi}}$.

Um perfil de estratégias mistas $p^{*}=\left(p_{1}^{*}, p_{2}^{*}, \ldots, p_{m_{i}}^{*}\right) \in \Delta$ é um equilíbrio de Nash em estratégias mistas quando $U_{i}\left(p_{i}^{*}, p_{-i}^{*}\right) \geq U_{i}\left(p, p_{-i}^{*}\right)$, para todo $p_{i} \in \Delta_{m_{i}}$. Isto é, nenhum jogador é motivado a trocar sua estratégia mista se os demais jogadores não o fizerem.

Todo perfil que representa um equilíbrio de Nash consiste em um perfil de estratégias dominantes.

Voltando ao jogo Par ou Impar, pode-se mostrar que o perfil de estratégias mistas $\boldsymbol{p}^{*}$ $=((1 / 2,1 / 2),(1 / 2,1 / 2))$ é um Equilíbrio de Nash. Pode-se verificar isso analisando a função utilidade. Primeiramente já foi visto que não há equilíbrio em estratégias puras. Se o jogador $g_{1}$ jogar par com probabilidade 1 (jogar sempre "par"), só resta ao jogador $g_{2}$ jogar ímpar com probabilidade 1 (jogar sempre "impar"); da mesma forma, se $g_{1}$ jogar ímpar com probabilidade 1, só resta a $g_{2}$ jogar par com probabilidade 1; sendo assim, não haverá equilíbrio de Nash. Procura-se, portanto, encontrar um equilíbrio de Nash quando os jogadores jogam com probabilidades entre 0 e 1 . A função utilidade do jogador $g_{1}$ é

$$
U_{1}(p)=\left(4 x_{1} x_{2}-2 x_{1}-2 x_{2}+1\right)=\left(2 x_{1}-1\right) \cdot\left(2 x_{2}-1\right)
$$


Fixando a probabilidade $x_{2}$ o termo $2 x_{2}-1$ é fixo e tem-se $U_{1}(p)$ em função do termo $2 x_{1}-1$. Em outras palavras, fixando a estratégia do jogador $g_{2}$, pode-se verificar o maior ganho para o jogador $g_{1}$.

Quando $x_{2}>1 / 2$ (o jogador II joga par em mais da metade das vezes), $2 x_{2}-1$ é positivo, então o jogador I maximiza sua utilidade (ganho), escolhendo $x_{1}=1$ (jogando sempre par); da mesma forma, quando $x_{2}<1 / 2$ (o jogador II joga par em menos da metade das vezes), $2 x_{2}-1$ é negativo, então o jogador 1 maximiza sua utilidade, escolhendo $x_{1}=0$ (sempre jogar ímpar). No entanto, quando $x_{1}=1$, o jogador II deve escolher claramente $x_{2}=$ 0 (jogar sempre impar) e, da mesma forma, quando $x_{1}=0$ (jogar sempre ímpar), o jogador II deve escolher $x_{2}=1$ (jogar sempre par). Isso mostra que, quando $x_{2} \neq 1 / 2$, o perfil não pode ser um equilíbrio de Nash.

Analogamente, se faz a mesma análise para a função utilidade do jogador II , concluindo-se que $x_{1} \neq 1 / 2$ não pode ser um equilíbrio de Nash. Então $x_{1}=1 / 2, x_{2}=1 / 2$ é o único equilíbrio possível.

Se $\boldsymbol{p}=((1 / 2,1 / 2),(1 / 2,1 / 2))$ então $U_{1}(\boldsymbol{p})=1 / 2$ e $U_{2}(\boldsymbol{p})=-1 / 2$

Observa-se que os jogadores de Par ou Ímpar, costumam variar suas jogadas de forma aleatória. No entanto, o conceito de estratégia mista compreende maior vantagem para um jogador quando este mantêm uma mesma estratégia em várias jogadas.

Von Neumann provou o teorema que estabelece que todo jogo com dois jogadores de soma zero admite uma solução (equilíbrio) em estratégias mistas. (BORTOLOSSI; GARBUGIO; SARTINI, 2017, p. 93).

John Nash provou a existência de um equilíbrio, que hoje leva seu nome, em estratégias mistas para jogos não cooperativos. (BORTOLOSSI; GARBUGIO; SARTINI, 2017, p. 9).

Em particular, a solução garantida pelo teorema de von Neumann equivale a um equilíbrio de Nash.

Serão discutidos no decorrer deste trabalho, jogos de dois jogadores, visando uma exemplificação mais acessível dos pressupostos da Teoria dos Jogos, bem como condizente com a aprendizagem dos envolvidos na pesquisa.

\subsubsection{EXEMPLOS}

Serão apresentados nesta seção alguns jogos não cooperativos e de jogada única, sendo que três desses jogos servem de objeto à presente pesquisa. 


\subsubsection{DILEMA DO PRISIONEIRO}

Possivelmente este é um dos exemplos mais conhecidos da Teoria dos Jogos. Albert W. Tucker (1905 - 1995), matemático canadense, orientador de John Nash, formulou este problema num seminário em 1950.

Dois homens cometem o mesmo crime e são capturados juntos, mas interrogados separadamente, quando lhes são propostas as opções: se ambos negarem o crime, serão condenados a 1 ano de prisão; se ambos confessarem, serão condenados a 5 anos; se um confessar e o outro negar, o que confessou será libertado e o outro será condenado a 10 anos de prisão.

Cada prisioneiro tem duas opções: cooperar com o seu cúmplice negando o crime ou trair seu cúmplice confessando o crime. O resultado de cada escolha depende da escolha do cúmplice mas, infelizmente, um não sabe o que o outro vai escolher. Esperando que o cúmplice escolha cooperar com ele, o mesmo pode negar; no entanto, esperando que o cúmplice o traia, o mesmo pode escolher confessar.

Pensando pela perspectiva do interesse coletivo (dos dois prisioneiros), o resultado esperado seria que ambos negassem, uma vez que isto reduziria o tempo total de pena dos dois, pois qualquer outra decisão seria pior para ambos. Mas cada um dos dois prisioneiros sente-se tentado a negar, pensando no seu próprio interesse. Então, uma possível maneira de um dos jogadores pensar seria que a opção negar parece menos arriscado, visto que um não confia no outro. Mas e se outro jogador não pensar da mesma maneira?

Seja qual for a escolha de um jogador, o outro jogador pode sempre reduzir sua sentença confessando: essa escolha conduz ao ponto chave do dilema.

De acordo com os pressupostos da Teoria dos Jogos, o Dilema do Prisioneiro apresenta como conjunto de estratégias puras: $S_{\mathrm{i}}=$ \{Confessar, Negar $\}$, tendo em vista que existem essas duas opções para os prisioneiros. Sendo assim, o conjunto de todos os perfis de estratégias puras desse jogo é: $\mathrm{S}=\{$ (Confessar, Confessar), (Confessar, Negar), (Negar, Confessar), (Negar, Negar)\}.

Associando a cada perfil de estratégia o número de anos de prisão correspondente e representado esse número como um valor negativo, já que é considerado como "perda", obtém-se os seguintes ganhos para o prisioneiro A:

$$
u_{\mathrm{A}}:\left(\mathrm{s}_{11}, \mathrm{~s}_{21}\right)=(\text { Confessar }, \text { Confessar }) \rightarrow-5
$$




$$
\begin{aligned}
& u_{\mathrm{A}}:\left(\mathrm{s}_{11}, \mathrm{~s}_{22}\right)=(\text { Confessar }, \text { Negar }) \rightarrow 0 \\
& u_{\mathrm{A}}:\left(\mathrm{s}_{12}, \mathrm{~s}_{21}\right)=(\text { Negar }, \text { Confessar }) \rightarrow-10 \\
& u_{\mathrm{A}}:\left(\mathrm{s}_{12}, \mathrm{~s}_{22}\right)=(\text { Negar }, \text { Negar }) \rightarrow-1 .
\end{aligned}
$$

Da mesma forma obtem-se os seguintes ganhos para o prisioneiro B:

$$
\begin{aligned}
& u_{\mathrm{B}}:\left(\mathrm{s}_{11}, \mathrm{~s}_{21}\right)=(\text { Confessar }, \text { Confessar }) \rightarrow-5 \\
& u_{\mathrm{B}}:\left(\mathrm{s}_{11}, \mathrm{~s}_{22}\right)=(\text { Confessar }, \text { Negar }) \rightarrow-10 \\
& u_{\mathrm{B}}:\left(\mathrm{s}_{12}, \mathrm{~s}_{21}\right)=(\text { Negar }, \text { Confessar }) \rightarrow 0 \\
& u_{\mathrm{B}}:\left(\mathrm{s}_{12}, \mathrm{~s}_{22}\right)=(\text { Negar }, \text { Negar }) \rightarrow-1 .
\end{aligned}
$$

A matriz payoff que representa esse dilema é:

\begin{tabular}{|c|c|c|c|}
\cline { 3 - 4 } \multicolumn{2}{c|}{} & \multicolumn{2}{c|}{ PRISIONEIRO B } \\
\cline { 2 - 4 } \multicolumn{2}{c|}{} & Confessar & Negar \\
\hline \multirow{2}{*}{ PRISIONEIRO A } & Confessar & $(-5,-5)$ & $(0,-10)$ \\
\cline { 2 - 4 } & Negar & $(-10,0)$ & $(-1,-1)$ \\
\hline
\end{tabular}

Cada prisioneiro quer diminuir ao máximo sua pena e, sendo assim, a estratégia dominante para cada um é confessar (em todas as opções, é sempre melhor confessar), e esta pode ser assim observada:

$u_{1}\left(s_{11}, s_{21}\right)=u_{1}($ Confessar, Confessar $)=-5>u_{1}\left(s_{12}, s_{21}\right)=u_{1}($ Negar, Confessar $)=-10$.

$u_{1}\left(s_{11}, s_{22}\right)=u_{1}($ Confessar, Negar $)=0 .>u_{1}\left(s_{12}, s_{22}\right)=u_{1}($ Negar, Negar $)=-1$.

A estratégia pura dominante obtida para o prisioneiro A é $s_{11}$ (Confessar). $u_{2}\left(s_{11}, s_{21}\right)=u_{2}($ Confessar, Confessar $)=-5>u_{2}\left(s_{11}, s_{22}\right)=u_{2}($ Confessar, Negar $)=-10$. $u_{2}\left(s_{12}, s_{21}\right)=u_{2}($ Negar, Confessar $)=0>u_{2}\left(s_{21}, s_{22}\right)=u_{2}($ Negar, Negar $)=-1$.

A estratégia pura dominante obtida para o prisioneiro B é $s_{21}$ (Confessar).

Essa situação-dilema traz como equilíbrio de Nash o perfil $\left(\mathrm{s}_{11}, \mathrm{~s}_{21}\right)=($ Confessar , Confessar), onde nenhum dos prisioneiros diminui sua pena mudando sozinho de estratégia. Como há estratégias dominantes para ambos os jogadores, o equilíbrio desse jogo é um perfil de estratégias dominantes. O Dilema do Prisioneiro tem solução em estratégias Puras.

De acordo com Pimentel (2007), esse jogo retrata as consequências de todas as tomadas de decisões e garante uma única alternativa como sendo a melhor solução para ambos. 


\subsubsection{JOGO SETE E MEIO}

Em 2002, Silvio Santos lançou mais um jogo de perguntas e respostas chamado Sete e Meio. Esse jogo era dividido em duas partes: a primeira continha vários participantes que disputavam entre si respondendo perguntas; a segunda continha apenas os dois participantes que tivessem respondido corretamente mais perguntas da primeira parte, podendo terminar o jogo com todo o prêmio, ou sem nada.

Os jogadores em cabines individuais devem escolher entre duas opções de cartas: Sete ou Meio (justificando o nome do programa), de modo que: se os dois participantes colaborarem escolhendo a carta "meio", dividem o prêmio do programa; se um escolher a carta "sete" e outro escolher a carta "meio", o que escolheu "sete" ganha todo o prêmio e o que escolheu "meio" ganha nada; se os dois colocarem a carta "sete", os dois ganham nada. Os jogadores podem comunicar-se antes de dar as cartas, tentando convencer o outro a tomar uma decisão favorável aos dois (escolher “meio").

Ocorre que os jogadores podem contrariar o que haviam combinado entre si e escolher “sete", pois essa decisão dá a oportunidade de ganhar tudo (pensando individualmente), visto que maximizar o ganho é a atitude comum de um jogador.

O dilema nesse caso é confiar ou não no oponente, uma vez que torna-se melhor para ambos dividirem o prêmio e, assim, os dois sairiam satisfeitos. No entanto, um dos jogadores pode pensar que o outro tentou lhe convencer a colocar "meio" para que o mesmo pudesse colocar "sete" e ficar com tudo.

A melhor estratégia para o grupo seria a cooperação, onde os dois terminam o jogo com metade do prêmio; mesmo não havendo um ganhador, o empate torna-se mais justo.

A Teoria dos Jogos apresenta para o jogo Sete e Meio o Conjunto de Estratégias Puras: $S_{\mathrm{i}}=\{$ Meio, Sete $\}$, sendo o Conjunto dos Perfis de Estratégia desse jogo: $\mathrm{S}=\{$ (Meio, Meio), (Meio, Sete), (Sete, Meio), (Sete, Sete)\}.

Sendo assim, como colocando a carta meio, ambos os jogadores dividem o prêmio, associa-se ao Perfil de Estratégia correspondente o número $1 \frac{1}{2}$, ou seja, metade do prêmio para o jogador A (por exemplo); da mesma forma, associa-se ao perfil correspondente o número 1, que representa o prêmio inteiro para o jogador $\mathrm{A}$ e, por sua vez, número -1, representando derrota (nenhum prêmio) para o jogador A. Tem-se então a seguinte Função Utilidade para o jogador A (analogamente representa-se a do jogador B):

$$
u_{\mathrm{A}}:\left(\mathrm{s}_{11}, \mathrm{~s}_{21}\right)=(\text { Meio }, \text { Meio }) \rightarrow 1 / 2
$$




$$
\begin{aligned}
& u_{\mathrm{A}}:\left(\mathrm{s}_{11}, \mathrm{~s}_{22}\right)=(\text { Meio }, \text { Sete }) \rightarrow-1 \\
& u_{\mathrm{A}}:\left(\mathrm{s}_{12}, \mathrm{~s}_{21}\right)=(\text { Sete }, \text { Meio }) \rightarrow 1 \\
& u_{\mathrm{A}}:\left(\mathrm{s}_{12}, \mathrm{~s}_{22}\right)=(\text { Sete }, \text { Sete }) \rightarrow-1
\end{aligned}
$$

\begin{tabular}{|c|c|c|c|}
\cline { 3 - 4 } \multicolumn{2}{c|}{} & \multicolumn{2}{c|}{ JOGADOR B } \\
\cline { 2 - 4 } \multicolumn{2}{c|}{} & Meio & Sete \\
\hline \multirow{2}{*}{ JOGADOR A } & Meio & $(1 / 2,1 / 2)$ & $(-1,1)$ \\
\cline { 2 - 4 } & Sete & $(1,-1)$ & $(-1,-1)$ \\
\hline
\end{tabular}

A estratégia dominante para qualquer um dos jogadores é trair, pois se um deles escolhe "sete", independente da escolha do outro, ou ele leva o prêmio ou nenhum dos dois leva. Observa-se essa estratégia da seguinte forma:

$$
\begin{aligned}
& u_{1}\left(s_{12}, s_{21}\right)=u_{1}(\text { Sete }, \text { Meio })=1>u_{1}\left(s_{11}, s_{21}\right)=u_{1}(\text { Sete }, \text { Sete })=1 / 2 . \\
& u_{1}\left(s_{12}, s_{22}\right)=u_{1}(\text { Sete }, \text { Meio })=-1 \geq u_{1}\left(s_{11}, s_{22}\right)=u_{1}(\text { Sete }, \text { Sete })=-1 .
\end{aligned}
$$

A estratégia pura dominante do jogador A é $s_{21}$ (Sete).

$u_{2}\left(s_{11}, s_{22}\right)=u_{2}($ Meio, Sete $)=1>u_{2}\left(s_{11}, s_{21}\right)=u_{2}($ Sete, Sete $)=-1$.

$u_{2}\left(s_{12}, s_{22}\right)=u_{2}($ Sete, Sete $)=-1 \geq u_{2}\left(s_{12}, s_{21}\right)=u_{2}($ Sete, Meio $)=-1$.

A estratégia pura dominante do jogador B é $s_{22}$ (Sete).

O equilíbrio de Nash, por sua vez, é o perfil de estratégias puras dominantes $\left(\mathrm{s}_{12}, \mathrm{~s}_{22}\right)$ $=($ sete, sete $)$, onde nenhum dos dois jogadores tem interesse em mudar de estratégia se o outro também não mudar.

\subsubsection{LE HER}

Toma-se um baralho comum de um mesmo naipe constituido de 13 cartas: um Ás, nove cartas numéricas, numeradas de 2 a 10, um Valete, uma Dama e um Rei e dois jogadores.

As 13 cartas do baralho são embaralhadas e inicia-se o jogo distribuindo-se uma carta para cada jogador e uma terceira carta é colocada na mesa. O primeiro jogador recebe uma carta que apenas ele vê; o segundo jogador também recebe uma carta que apenas ele vê; uma terceira carta é colocada sobre a mesa, de forma que ninguém vê. Ganha quem tiver a carta de maior valor, dentre as três, sendo que os valores das cartas em questão são: um para o Ás, o valor numérico para cada cartas de 2 até 10; 11 para o Valete, 12 para Dama e 13 para o Rei.

O primeiro jogador deve decidir se mantém a sua carta ou a troca com a carta do 
segundo jogador (que não pode se recusar a fazer a troca). Depois, o segundo jogador deve decidir se mantém a sua carta ou a troca com a carta da mesa.

O primeiro jogador decide apenas com base no valor da sua carta: se a mesma tiver um valor baixo, suas chances aumentam se trocar de carta. O segundo jogador torna-se influenciado pela decisão do primeiro: se este decidir não trocar, significa que sua carta pode ter um valor alto. No entanto, se o primeiro jogador decidir tocar, o segundo saberá quem dos dois tem uma carta maior.

Se o primeiro jogador decidir não trocar a carta, o segundo jogador decidi entre ficar com sua carta ou optar pela carta da mesa. Se o primeiro jogador decidir trocar sua carta, o segundo jogador pode decidir entre ficar com a carta que recebeu (visto que conhece a carta que agora está com o seu adversário) ou trocar com a carta da mesa, não garantindo sua vitória.

Nesse jogo a decisão do primeiro jogador depende da carta da qual dispõe e principalmente da estratégia adotada. E isso influencia na decisão do segundo jogador, também em termos estratégicos (não é interessante a nenhum deles ficar com uma carta de valor baixo).

Torna-se cabível mencionar que o primeiro jogador também pode blefar, ou seja, não trocar mesmo tendo uma carta de valor baixo. Além disso, a carta da mesa, desconhecida pelos dois jogadores, pode interferir em todas as estratégias assumidas pelos jogadores.

Sejam: $\mathrm{A}=$ valor da carta do primeiro jogador; $\mathrm{B}=$ valor da carta do segundo jogador e $\mathrm{C}=$ valor da carta da mesa. A análise desse jogo deve levar em conta seis possibilidades diferentes: $\mathrm{A}<\mathrm{B}<\mathrm{C}$ ou $\mathrm{A}<\mathrm{C}<\mathrm{B}$ ou $\mathrm{B}<\mathrm{A}<\mathrm{C}$ ou $\mathrm{B}<\mathrm{C}<\mathrm{A}$ ou $\mathrm{C}<\mathrm{A}<\mathrm{B}$ ou $\mathrm{C}<\mathrm{B}<\mathrm{A}$. Tendo em vista essas seis possibilidades apontadas anteriormente, torna-se possivel obter no jogo Le Her, três Matrizes Payoff diferentes.

Se $\mathrm{A}<\mathrm{B}<\mathrm{C}$ ou $\mathrm{B}<\mathrm{A}<\mathrm{C}$ :

$2^{\circ}$ JOGADOR

\begin{tabular}{|c|c|c|c|}
\cline { 3 - 4 } \multicolumn{2}{c|}{} & \multicolumn{2}{c|}{} \\
\cline { 2 - 4 } & Trocar & Não Trocar \\
\hline \multirow{2}{*}{$1^{\circ}$ JOGADOR } & Trocar & $(-1,1)$ & $(-1,-1)$ \\
\cline { 2 - 4 } & Não Trocar & $(-1,1)$ & $(-1,-1)$ \\
\hline
\end{tabular}




\begin{tabular}{|c|c|c|c|}
\hline \multicolumn{2}{|c|}{$\mathrm{Se} C<\mathrm{B}<\mathrm{A}$ ou $\mathrm{B}<\mathrm{A}<\mathrm{C}$ : } & \multicolumn{2}{|c|}{$2^{\circ} \mathrm{JOGADOR}$} \\
\hline & & Trocar & Não Trocar \\
\hline \multirow[t]{2}{*}{$1^{\circ} \mathrm{JOGADOR}$} & Trocar & $(-1,-1)$ & $(-1,1)$ \\
\hline & Não Trocar & $(1,-1)$ & $(1,-1)$ \\
\hline
\end{tabular}

\begin{tabular}{|c|c|c|c|}
\hline \multicolumn{2}{|c|}{ Se $\mathrm{A}<\mathrm{B}<\mathrm{C}$ ou $\mathrm{C}<\mathrm{A}<\mathrm{B}$ : } & \multicolumn{2}{|c|}{$2^{\circ} \mathrm{JOGADOR}$} \\
\hline & & Trocar & Não Trocar \\
\hline \multirow[t]{2}{*}{$1^{\circ} \mathrm{JOGADOR}$} & Trocar & $(1,-1)$ & $(1,-1)$ \\
\hline & Não Trocar & $(-1,-1)$ & $(-1,1)$ \\
\hline
\end{tabular}

Analisando esse jogo do ponto de vista das estratégias puras, não se pode encontrar uma estratégia dominante, uma vez que nenhuma escolha independe da escolha do outro jogador. Também não existe um equilíbrio de Nash em estratégias puras, ou seja, sempre é possível a cada um dos jogadores mudar a escolha e melhorar o resultado. Se a carta do jogador tem valor alto, cabe a ele trocá-la, caso contrário é melhor que ele não a troque.

O jogo não admite uma situação favorável aos dois jogadores: só pode haver um vencedor ou nenhum: ou um deles ganha (o que termina com a carta maior), ou ambos perdem (se a carta maior for a da mesa).

Le Her é um jogo de soma zero, que envolve blefe. Dentro da Teoria dos Jogos, as táticas do blefe são tratáveis matematicamente, de modo que dissimular corresponde a uma estratégia racional em jogos desse tipo.

Como o presente trabalho concentra-se apenas nos pressupostos básicos dessa teoria, não cabe aqui um aprofundamento no estudo desse tipo de jogo.

\subsubsection{JOGO DO COVARDE (GAME OF CHICKEN ${ }^{6}$ )}

O filme JUVENTUDE TRANSVIADA ${ }^{7}$ de 1955 apresenta uma cena que representa esse jogo: dois adolescentes estão pilotando carros roubados na direção de um abismo e se submetem a um teste de coragem, onde aquele que desviar o carro primeiro será chamado de

6 Nos Estados Unidos, as pessoas covardes são chamadas de "chicken" (galinhas).

7 É um filme norte-americano, do gênero drama, dirigido por Nicholas Ray e estrelado por Jim Stark e Natalie Wood. 
covarde.

Nesse jogo, se ambos não desviarem, o resultado é o pior possível, visto que isso acarreta em um grave acidente; se ambos desviarem ao mesmo tempo, o resultado não é favorável para nenhum dos jogadores, uma vez que ambos terminam o jogo sendo chamados de covardes; se um deles desviar primeiro, tem-se o melhor resultado para esse jogo, ou seja, apenas um deles fica sendo chamado de covarde.

Em suma, ou ao menos um dos jogadores termina o jogo sendo chamado de covarde, ou ambos podem se dar mal.

O Conjunto de Estratégias Puras desse jogo é: $S_{\mathrm{i}}=\{$ desviar, não desviar $\}$ e o Conjunto de todos os Perfis de Estratégia é $S=\{$ (desviar, desviar), (desviar, não desviar), (não desviar, desviar), (não desviar, não desviar)\} .

Define-se as funções utilidades da seguinte forma: ao jogador A, atribui-se o número 1 aos perfis onde o mesmo desvia; dessa forma, atribui-se o número 2 ao perfil onde seu oponente desvia primeiro; atribui-se o número 0 quando ambos os jogadores não desviam (obviamente, se procede de maneira análoga para o jogador B):

$$
\begin{aligned}
& u_{\mathrm{A}}:\left(\mathrm{s}_{11}, \mathrm{~s}_{21}\right)=(\text { Desviar, Desviar }) \rightarrow 1 \\
& u_{\mathrm{A}}:\left(\mathrm{s}_{11}, \mathrm{~s}_{22}\right)=(\text { Desviar, Não Desviar }) \rightarrow 1 \\
& u_{\mathrm{A}}:\left(\mathrm{s}_{12}, \mathrm{~s}_{21}\right)=(\text { Não Desviar, Desviar }) \rightarrow 2 \\
& u_{\mathrm{A}}:\left(\mathrm{s}_{12}, \mathrm{~s}_{22}\right)=(\text { Não Desviar, Desviar }) \rightarrow 0
\end{aligned}
$$

Tem-se então a Matriz Payoff do jogo do Covarde:

\begin{tabular}{|c|c|c|c|}
\cline { 3 - 4 } \multicolumn{2}{c|}{} & \multicolumn{2}{c|}{ JOGADOR B } \\
\cline { 2 - 4 } \multicolumn{2}{c|}{} & Desviar & Não Desviar \\
\hline \multirow{2}{*}{ JOGADOR A } & Desviar & $(1,1)$ & $(1,2)$ \\
\cline { 2 - 4 } & Não Desviar & $(2,1)$ & $(0,0)$ \\
\hline
\end{tabular}

Esse jogo não admite uma estratégia dominante em estratégias puras, pois não há um perfil onde a escolha de um dos jogadores não dependa da escolha do outro para obtenção do ganho: não ser chamado de covarde. Um jogador não ganha se o outro não desviar. $u_{1}\left(s_{11}, s_{21}\right)=u_{1}$ (Desviar, Desviar $)=1<u_{1}\left(s_{12}, s_{21}\right)=u_{1}($ Não Desviar, Desviar $)=2$. $u_{1}\left(s_{11}, s_{22}\right)=u_{1}($ Desviar, Não Desviar $)=1<u_{1}\left(s_{12}, s_{22}\right)=u_{1}$ (Não Desviar, Não Desviar $)=2$. $u_{2}\left(s_{11}, s_{22}\right)=u_{2}$ (Não Desviar, Desviar $)=1 \leq u_{2}\left(s_{11}, s_{21}\right)=u_{2}($ Desviar, Desviar $)=1$ $u_{2}\left(s_{11}, s_{22}\right)=u_{2}$ (Não Desviar, Não Desviar $)=0<u_{2}\left(s_{12}, s_{22}\right)=u_{2}$ (Não Desviar, Desviar $)=1$. No entanto, o jogo do Covarde admite dois pontos onde nenhum dos dois jogadores 
tem interesse em mudar sozinho de estratégia, ou seja, dois equilíbrios de Nash em estratégias puras: $\left(s_{11}, s_{22}\right)=($ Desviar, Não Desviar $)$ e $\left(s_{12}, s_{21}\right)=($ Não Desviar, Desviar $)$. Portanto, esse jogo tem duas soluções em estratégias puras.

\subsubsection{BATALHA DOS SEXOS}

Um casal de namorados deseja decidir qual programa farão num específico dia: ir a uma partida de futebol ou ir a um show de música popular, que acontecem ao mesmo tempo. O rapaz prefere ir ao futebol a ir ao show de música popular e a garota prefere ir ao show de música a ir ao futebol.

Esta situação pode ser vista como um jogo, em que os jogadores são o rapaz e a garota. Eles obterão a maior recompensa caso escolham o mesmo programa e consigam se encontrar. Ainda que a garota prefira ir ao show a ir ao futebol e o rapaz prefira o futebol ao show, nenhum dos dois quer fazer seu programa favorito sozinho e, assim, o rapaz prefere ir ao show com a garota a ir ao futebol sozinho e a garota, da mesma forma, prefere ir ao futebol com o rapaz a ir sozinha ao show.

O conjunto de estratégias puras é $S_{\mathrm{i}}=\{$ futebol, show $\}$ e o conjunto de todos os perfis de estratégia é $S=\{($ futebol, futebol), (futebol, show), (show, futebol), (show, show) $\}$. Os ganhos para o rapaz (jogador 1), que são pensados de forma análoga aos ganhos da garota (jogador 2) são:

$$
\begin{array}{ll}
u_{1}:\left(\mathrm{s}_{11}, \mathrm{~s}_{21}\right)=(\text { Futebol }, \text { Futebol }) \rightarrow 2 & u_{1}:\left(\mathrm{s}_{11}, \mathrm{~s}_{22}\right)=(\text { Futebol }, \text { Show }) \rightarrow 0 \\
u_{1}:\left(\mathrm{s}_{12}, \mathrm{~s}_{21}\right)=(\text { Show }, \text { Futebol }) \rightarrow 0 & u_{1}:\left(\mathrm{s}_{12}, \mathrm{~s}_{22}\right)=(\text { Show }, \text { Show }) \rightarrow 1
\end{array}
$$

\begin{tabular}{|c|c|c|c|}
\cline { 3 - 3 } \multicolumn{2}{c|}{} & \multicolumn{2}{|c|}{ GAROTA } \\
\cline { 3 - 4 } \multicolumn{2}{c|}{} & Futebol & Show \\
\hline \multirow{2}{*}{ RAPAZ } & Futebol & $(2,1)$ & $(0,0)$ \\
\cline { 2 - 4 } & Show & $(0,0)$ & $(1,2)$ \\
\hline
\end{tabular}

O jogo da Batalha dos Sexos não possui estratégia dominante, pois apesar dos agentes preferirem programas diferentes, um deles só será beneficiado se o outro também for, ou seja, se o rapaz e a moça conseguirem se encontrar.

$$
u_{1}\left(s_{11}, s_{21}\right)=u_{1}(\text { Futebol }, \text { Futebol })=2>u_{1}\left(s_{12}, s_{21}\right)=u_{1}(\text { Show }, \text { Futebol })=0 \text {. }
$$




$$
\begin{aligned}
& \left.u_{1}\left(s_{11}, s_{22}\right)=u_{1} \text { (Futebol, Show }\right)=0<u_{1}\left(s_{12}, s_{22}\right)=u_{1}(\text { Show }, \text { Show })=1 . \\
& \left.u_{2}\left(s_{12}, s_{22}\right)=u_{2} \text { (Show, Show }\right)=2>u_{2}\left(s_{12}, s_{21}\right)=u_{2}(\text { Show }, \text { Futebol })=0 . \\
& \left.u_{2}\left(s_{11}, s_{22}\right)=u_{2} \text { (Futebol, Show }\right)=0<u_{2}\left(s_{11}, s_{21}\right)=u_{2}(\text { Futebol, Futebol })=1 .
\end{aligned}
$$

Os perfis onde o rapaz e a garota se encontram: $\left(\mathrm{s}_{11}, \mathrm{~s}_{21}\right)=\left(\right.$ Futebol , Futebol) e $\left(\mathrm{s}_{12}\right.$, $\left.\mathrm{s}_{22}\right)=($ Show, Show $)$ são equilíbrios de Nash da Batalha dos Sexos, que tem duas soluções em estratégias puras.

Esse tipo de jogo serve como representação geral daquelas situações de interação estratégica em que os jogadores ganham sempre que coordenam suas decisões, mesmo tendo preferências distintas sobre que tipo de coordenação deve ser adotada.

\subsubsection{BARGANHA COM ULTIMATO ${ }^{8}$}

Duas pessoas estão em salas separadas, sem poderem trocar informação. Um sorteio com uma moeda decide quem fará uma proposta de dividir um prêmio de 100 reais em notas de 1 real. A pessoa que ganha nesse sorteio deve fazer a proposta de como dividir o dinheiro, sendo que a outra pessoa só pode dizer sim ou não (aceita ou não). Se a resposta for sim, o negócio é feito e se a resposta for não, ninguém ganha nada. Ambas conhecem as regras.

O jogador que faz a proposta, pode oferecer de 99 reais a 1 real. Se oferecer 50 reais a divisão seria justa e prontamente aceita, pois esse é o valor mais alto a se oferecer, visto que o jogador que faz a proposta não pode querer terminar o jogo com menos que seu oponente (de acordo com os ideais dessa teoria, um jogador não entra em um jogo para querer perder). No entanto, se o jogador proponente for mais audacioso, pode oferecer menos que a metade. $\mathrm{O}$ jogador que responde, deve pensar se aceita qualquer oferta, mesmo se o outro ficar com a maior parte, ou se prefere recusar uma oferta baixa e ficar com nada, mas assim punir o proponente. Por exemplo: aceitar 10 reais e deixar o outro com 90, pois 10 reais é melhor que nada ou recusar pois 10 é pouco? E se fosse oferecido 1 real?

O Jogo Barganha com Ultimato é intrigante pois mostra que nem todos agem de forma racional e no fim se prejudicam a si mesmos. Alguns rejeitam uma oferta baixa para manter a reputação ou a auto-estima, preferindo que o outro jogador também fique com zero. Outros, ao fazer a oferta, acham melhor ficar com metade do prêmio e não correr o risco de ficar com nada.

8 Esse tipo de jogo foi projetado pelo economista alemão Werner Guth, por volta de 1982. 
Para o proponente, oferecer uma quantia muito baixa é arriscado, pois pode ser rejeitada. Mas aqui está o enigma: por que alguém rejeitaria uma oferta baixa, visto que só tem como opções aceitar algo ou fica sem nada? A única opção racional economicamente é aceitar que algo é melhor que nada. Se o proponente pensar dessa forma, fará a menor oferta possível, pois o respondente vai aceitar. Essa é a análise via Teoria dos Jogos, que assume que pessoas são racionais e com auto-interesse, mas não é como a maioria das pessoas jogam. Segundo economistas e pesquisadores desse jogo, testado várias vezes e em muitas culturas e países, há uma tendência para o proponente fazer divisões de cinquenta reais para cada ou de 60 reais para um e 40 reais para o outro, bem como para o respondente rejeitar ofertas de menos de vinte reais. Isso porque as pessoas são influenciadas por emoções que repercutem em relações entre egoísmo e justiça; entre cooperação e competição.

Pode-se considerar que o jogador I é o proponente e o jogador II o respondente. O conjunto de estratégias puras do jogador I é $S_{1}=\{99$ e 1,98 e 2,97 e 3, .., 50 e 50$\}$. O conjunto de estratégias puras do jogador 2 é $S_{2}=\{S i m$, Não $\}$. Logo o conjunto de todos os perfis de estratégia puras é $S=\{(99$ e $1, \operatorname{Sim}),(99$ e 1, Não), (98 e 2, Sim), (98 e 2, Não),..., $(50$ e $50, \operatorname{Sim})\}$.

Para o proponente, como sendo o jogador I, por exemplo, tem-se:

$$
\begin{aligned}
& u_{\mathrm{I}}:\left(\mathrm{s}_{11}, \mathrm{~s}_{21}\right)=(99 \text { e } 1, \mathrm{Sim}) \rightarrow 99 \\
& u_{\mathrm{I}}:\left(\mathrm{s}_{11}, \mathrm{~s}_{22}\right)=(99 \text { e } 1, \mathrm{Não}) \rightarrow 0 \\
& u_{\mathrm{I}}:\left(\mathrm{s}_{12}, \mathrm{~s}_{21}\right)=(98 \text { e } 2, \mathrm{Sim}) \rightarrow 98 \\
& u_{\mathrm{I}}:\left(\mathrm{s}_{12}, \mathrm{~s}_{22}\right)=(98 \text { e } 2, \mathrm{Não}) \rightarrow 0 \\
& \vdots \\
& u_{\mathrm{I}}:\left(\mathrm{s}_{1} 50, \mathrm{~s}_{21}\right)=(50 \text { e } 50, \mathrm{Sim}) \rightarrow 50 \\
& u_{\mathrm{I}}:\left(\mathrm{s}_{1} 50, \mathrm{~s}_{22}\right)=(50 \text { e } 50, \mathrm{Não}) \rightarrow 0
\end{aligned}
$$

Para o respondente (jogador II) tem-se:

$$
\begin{aligned}
& u_{\mathrm{II}}:\left(\mathrm{s}_{11}, \mathrm{~s}_{21}\right)=(99 \text { e } 1, \mathrm{Sim}) \rightarrow 1 \\
& u_{\mathrm{II}}:\left(\mathrm{s}_{11}, \mathrm{~s}_{22}\right)=(99 \text { e } 1, \mathrm{Não}) \rightarrow 0 \\
& u_{\mathrm{II}}:\left(\mathrm{s}_{12}, \mathrm{~s}_{21}\right)=(98 \text { e } 2, \mathrm{Sim}) \rightarrow 2 \\
& u_{\mathrm{II}}:\left(\mathrm{s}_{12}, \mathrm{~s}_{22}\right)=(98 \text { e } 2, \mathrm{Não}) \rightarrow 0 \\
& \vdots \\
& u_{\mathrm{I}}:\left(\mathrm{s}_{1} 50, \mathrm{~s}_{21}\right)=(50 \text { e } 50, \mathrm{Sim}) \rightarrow 50 \\
& u_{\mathrm{I}}:\left(\mathrm{s}_{1} 50, \mathrm{~s}_{22}\right)=(50 \text { e } 50, \text { Não }) \rightarrow 0
\end{aligned}
$$

Neste caso, a Matriz Payoff do Jogo Barganha com Ultimato é: 


\begin{tabular}{|c|c|c|c|}
\hline & & \multicolumn{2}{|c|}{ JOGADOR II } \\
\hline & & Sim & Não \\
\hline \multirow{4}{*}{ JOGADOR I } & 99 e 1 & $(99,1)$ & $(0,0)$ \\
\hline & 98 e 2 & $(98,2)$ & $(0,0)$ \\
\hline & $\vdots$ & $\vdots$ & $\vdots$ \\
\hline & 50 e 50 & $(50,50)$ & $(0,0)$ \\
\hline
\end{tabular}

A estratégia dominante para o proponente é dividir o prêmio em 99 e 1 (melhor ganho possível); já a estratégia dominante para o respondente é dizer Sim (ganho maior que zero). $u_{\mathrm{I}}\left(s_{11}, s_{21}\right)=u_{\mathrm{I}}(99$ e $1, \operatorname{Sim})=99>u_{\mathrm{I}}\left(s_{12}, s_{21}\right)=u_{\mathrm{I}}(98$ e $2, \operatorname{Sim})=98>\ldots>u_{\mathrm{I}}\left(s_{150}, s_{21}\right)=$ $=u_{\mathrm{I}}(50$ e $50, \mathrm{Sim})=50$.

$u_{\mathrm{I}}\left(s_{11}, s_{22}\right)=u_{\mathrm{I}}(99$ e $1, \mathrm{Não})=0=\ldots=u_{\mathrm{I}}\left(s_{151}, s_{22}\right)=u_{\mathrm{I}}(50$ e $50, \mathrm{Não})=0$.

A estratégia dominante para o jogador I é $\mathrm{s}_{11}=99$ e 1 , que lhe garante o maior ganho possível.

$$
\begin{aligned}
& u_{\mathrm{II}}\left(s_{11}, s_{21}\right)=u_{\mathrm{II}}(99 \text { e } 1, \operatorname{Sim})=1>u_{\mathrm{II}}\left(s_{11}, s_{22}\right)=u_{\mathrm{II}}(99 \text { e } 1, \text { Não })=0 \\
& u_{\mathrm{II}}\left(s_{12}, s_{21}\right)=u_{\mathrm{II}}(98 \text { e } 2, \operatorname{Sim})=2>u_{\mathrm{II}}(98 \text { e } 2, \mathrm{Não})=0 . \\
& \vdots \\
& u_{\mathrm{II}}\left(s_{12}, s_{21}\right)=u_{\mathrm{II}}(50 \text { e } 50, \mathrm{Sim})=49>u_{\mathrm{II}}(50 \text { e } 50, \mathrm{Não})=0
\end{aligned}
$$

Só resta como estratégia dominante ao jogador II a estratégia $\mathrm{s}_{21}=$ Sim, com a qual ele obtém algum ganho.

O perfil de estratégias dominantes: $\left(\mathrm{s}_{11}, \mathrm{~s}_{12}\right)=(99$ e 1 , Sim $)$ é um equilíbrio de Nash em estratégias puras do jogo Barganha com Ultimato.

\subsubsection{PEDRA, PAPEL, TESOURA ${ }^{9}$}

Duas pessoas devem mostrar uma a outra, ao mesmo tempo, um símbolo a ser feito com uma das mãos. Elas têm três opções de símbolos: mão fechada, que significa "pedra"; mão esticada, que significa "papel"; dois dedos esticados, que significa "tesoura". Há então as seguintes regras: pedra "quebra" a tesoura, ou seja, se uma escolhe pedra e a outra escolhe tesoura, ganha quem escolhe pedra; papel "embrulha" a pedra, ou seja, se uma escolhe papel e

9 Esse jogo surgiu na China (San sukumi ken), mas ficou muito popular no Japão, denominado e propagado como “jokenpô". 
a outra escolhe pedra, ganha quem escolhe papel; tesoura "corta" o papel, ou seja, se uma escolhe tesoura e a outra escolhe papel, ganha quem escolhe tesoura.

Esse jogo, assim como ocorre com o Par ou Ímpar, é utilizado por indivíduos em situações de escolhas, apesar de ser, teoricamente, um jogo infantil.

Trata-se de um jogo de dois jogadores de soma zero e sua matriz de payoff é a seguinte:

\begin{tabular}{|c|c|c|c|c|}
\cline { 3 - 5 } \multicolumn{2}{c|}{} & \multicolumn{3}{c|}{ JOGADOR B } \\
\cline { 2 - 5 } \multicolumn{2}{c|}{} & Pedra & Papel & Tesoura \\
\hline \multirow{3}{*}{ JOGADOR A } & Pedra & $(0,0)$ & $(-1,1)$ & $(1,-1)$ \\
\cline { 2 - 5 } & Papel & $(1,-1)$ & $(0,0)$ & $(-1,1)$ \\
\cline { 2 - 5 } & Tesoura & $(-1,1)$ & $(1,-1)$ & $(0,0)$ \\
\hline
\end{tabular}

Assim como no jogo Par ou Ímpar, não há estratégias dominantes, nem tão pouco um equilíbrio de Nash em estratégias puras. Sendo assim, deve-se buscar uma solução em estratégias mistas. Para cada jogador o conjunto de estratégias mistas é do tipo

$$
\begin{gathered}
\left\{\left(x_{1}, x_{2}, 1-x_{1}-x_{2}\right), 0 \leq x_{1} \leq 1,0 \leq x_{2} \leq 1\right\} \\
\Delta=\left\{\left(\left(x_{1}, x_{2}, 1-x_{1}-x_{2}\right),\left(y_{1}, y_{2}, 1-y_{1}-y_{2}\right)\right), 0 \leq x_{1} \leq 1,0 \leq x_{2} \leq 1,0 \leq y_{1} \leq 1,0\right. \\
\left.\leq y_{2} \leq 1\right\}
\end{gathered}
$$

A função utilidade para o jogador A é então $U_{\mathrm{A}}(\mathrm{p})=\mathrm{x}_{1} \mathrm{y}_{1}\left(\mathrm{u}_{\mathrm{A}}(\right.$ pedra, pedra $\left.)\right)+\mathrm{x}_{1} \mathrm{y}_{2}\left(\mathrm{u}_{\mathrm{A}}(\right.$ pedra, papel $\left.)\right)+\mathrm{x}_{1}\left(1-\mathrm{y}_{1}-\mathrm{y}_{2}\right)\left(\mathrm{u}_{\mathrm{A}}(\right.$ pedra, tesoura $\left.)\right)+$ $\mathrm{x}_{2} \mathrm{y}_{1}\left(\mathrm{u}_{\mathrm{A}}(\right.$ papel, pedra $\left.)\right)+\mathrm{x}_{2} \mathrm{y}_{2}\left(\mathrm{u}_{\mathrm{A}}(\right.$ papel, papel $\left.)\right)+\mathrm{x}_{2}\left(1-\mathrm{y}_{1}-\mathrm{y}_{2}\right)\left(\mathrm{u}_{\mathrm{A}}(\right.$ papel, tesoura $\left.)\right)+\left(1-\mathrm{x}_{1}-\right.$ $\left.\mathrm{x}_{2}\right) \mathrm{y}_{1}\left(\mathrm{u}_{\mathrm{A}}(\right.$ tesoura, pedra $\left.)\right)+\left(1-\mathrm{x}_{1}-\mathrm{x}_{2}\right) \mathrm{y}_{2}\left(\mathrm{u}_{\mathrm{A}}(\right.$ tesoura, papel $\left.)\right)+\left(1-\mathrm{x}_{1}-\mathrm{x}_{2}\right)\left(1-\mathrm{y}_{1}-\right.$ $\left.\mathrm{y}_{2}\right)\left(\mathrm{u}_{\mathrm{A}}(\right.$ tesoura, tesoura $\left.)\right)=\mathrm{x}_{1} \mathrm{y}_{1 .} 0+\mathrm{x}_{1} \mathrm{y}_{2}(-1)+\mathrm{x}_{1}\left(1-\mathrm{y}_{1}-\mathrm{y}_{2}\right)+\mathrm{x}_{2} \mathrm{y}_{1}+\mathrm{x}_{2} \mathrm{y}_{2 .} 0+\mathrm{x}_{2}\left(1-\mathrm{y}_{1}-\mathrm{y}_{2}\right)(-$ $1)+\left(1-\mathrm{x}_{1}-\mathrm{x}_{2}\right) \mathrm{y}_{1}(-1)+\left(1-\mathrm{x}_{1}-\mathrm{x}_{2}\right) \mathrm{y}_{2}+\left(1-\mathrm{x}_{1}-\mathrm{x}_{2}\right)\left(1-\mathrm{y}_{1}-\mathrm{y}_{2}\right) .0=-\mathrm{x}_{1} \mathrm{y}_{2}+\mathrm{x}_{1}-\mathrm{x}_{1} \mathrm{y}_{1}-\mathrm{x}_{1} \mathrm{y}_{2}+$ $\mathrm{x}_{2} \mathrm{y}_{1}-\mathrm{x}_{2}+\mathrm{x}_{2} \mathrm{y}_{1}+\mathrm{x}_{2} \mathrm{y}_{2}-\mathrm{y}_{1}+\mathrm{x}_{1} \mathrm{y}_{1}+\mathrm{x}_{2} \mathrm{y}_{1}+\mathrm{y}_{2}-\mathrm{x}_{1} \mathrm{y}_{2}-\mathrm{x}_{2} \mathrm{y}_{2}=-3 \mathrm{x}_{1} \mathrm{y}_{2}+3 \mathrm{x}_{2} \mathrm{y}_{1}+\mathrm{x}_{1}-\mathrm{x}_{2}-\mathrm{y}_{1}+\mathrm{y}_{2}$.

Analogamente, $U_{\mathrm{B}}(\mathrm{p})=-\left(-3 \mathrm{x}_{1} \mathrm{y}_{2}+3 \mathrm{x}_{2} \mathrm{y}_{1}+\mathrm{x}_{1}-\mathrm{x}_{2}-\mathrm{y}_{1}+\mathrm{y}_{2}\right)$.

Pode-se provar que $\boldsymbol{p}^{*}=((1 / 3,1 / 3,1 / 3),(1 / 3,1 / 3,1 / 3))$ é um Equilíbrio de Nash. 


\section{CAPÍTULO 2}

\section{A TEORIA DOS JOGOS EM SALA DE AULA}

"Ou você tem uma estratégia ou é parte da estratégia de alguém." (Alvin Tofler)

A vida está repleta de conflitos, nos mais variados contextos. Uma das características básicas das relações conflituosas é que o seu resultado depende da combinação de estratégias selecionadas pelos envolvidos.

A promoção de espaços para o "aprender a pensar" apresenta-se como uma necessidade das práticas escolares vigentes, uma vez que torna-se essencial ao exercício da cidadania a competência de analisar um problema e tomar decisões sobre o mesmo (BRASIL, 2006, p. 83); nesse aspecto estão incluídas situações que envolvem conflito.

Segundo os Parâmetros Curriculares Nacionais - Ensino Médio (PCN+) (BRASIL, 2002), o currículo escolar deve oferecer maiores condições de contribuir com a formação de pessoas mais aptas e autônomas em suas escolhas. Torna-se importante, então, capacitar os alunos a tomarem suas próprias decisões em situações problemáticas, contribuindo assim para o desenvolvimento do educando como pessoa humana e como cidadão.

E conforme os Parâmetros Curriculares Nacionais (BRASIL, 1998) o uso de jogos são elementos interessantes para o desenvolvimento de habilidades diante de situações-problema.

Os jogos constituem uma forma interessante de propor problemas, pois permitem que estes sejam apresentados de modo atrativo e favorecem a criatividade na elaboração de estratégias de resolução e busca de soluções. Propiciam a simulação de situações-problema que exigem soluções vivas e imediatas, o que estimula o planejamento das ações: possibilitam a construção de uma atitude positiva perante os erros, uma vez que as situações sucedem-se rapidamente e podem ser corrigidas de forma natural, no decorrer da ação, sem deixar marcas negativas (BRASIL, 1998, p. 46)

Tomar uma decisão ou fazer escolhas, em qualquer contexto, corresponde a um processo cognitivo que, através dele, procura-se resolver um problema ou um dilema. Uma tomada de decisão, então, corresponde à definição de melhores recursos para uma ação que irá gerar um resultado. Trata-se de uma atividade que permeia todas as funções humanas, podendo, então, ser considerada uma habilidade essencial. 
Assim sendo, torna-se fundamental, dentro da perspectiva de educação para a cidadania, que o aluno consiga desenvolver a capacidade de lidar com situações-problema de diversos contextos, bem como que saiba se posicionar de maneira crítica, usando a argumentação como forma de mediar conflitos e de tomar decisões coletivas (BRASIL, 1997, p. 107).

Situações de jogos de conflito, ou situações-dilema, podem contribuir para a formação do indivíduo, no que se refere ao desenvolvimento de estratégias, de argumentação e de tomada de decisão, consistindo então em uma prática de sociabilidade.

Trabalhar, dentro do ambiente escolar, processos que favoreçam o desenvolvimento da habilidade de tomar decisões objetiva a formação de indivíduos mais capacitados para atuar em sociedade.

Dentro dessa perspectiva, problemas apresentados no contexto da Teoria dos Jogos, criam um espaço onde os envolvidos (jogadores) têm a oportunidade de exercitar a intuição e a criatividade, bem como de lidar com situações imprevisíveis. Essas situações de jogos trazem a necessidade do indivíduo (jogador) tomar decisões para alcançar uma solução para o jogo.

O confronto de escolhas presentes em situações que envolvem "jogadas", explora a relação intrínseca entre colaboração e competição que se faz presente nesse contexto, podendo ser levada para dentro da sala de aula, a fim de fomentar atitudes que aumentem as competências individuais.

Dentro da linha de pesquisa proposta neste trabalho, que consiste em levar a Teoria dos Jogos para o ensino médio em escolas públicas, há interessantes estudos. Alguns são citados a seguir.

Kasper (2017) levantou a questão do uso da Teoria dos Jogos com o objetivo de tornar o ensino de Matemática mais participativo e interessante aos alunos. Para tanto, o autor propõe trabalhar em sala de aula com alunos do Ensino Médio, o Dilema do Prisioneiro, com outros jogos elaborados pelo autor, de modo a estimular nos alunos a percepção de cada estratégia, bem como a organização das informações apresentadas no enunciado de cada situação de jogo. Segundo o autor,

Os estudos realizados indicaram que a Teoria dos Jogos constitui uma possibilidade promissora com potencial de contribuir para uma concepção curricular adequada às necessidades educativas atuais, sobretudo no que diz respeito a tornar o ensino da Matemática mais participativo e garantir que o ambiente escolar seja um espaço que assegure a imaginação, a investigação e o prazer em aprender. (KASPER, 2017, p.50). 
Pereira (2014) também utilizou a Teoria dos Jogos como elemento motivador no ensino da Matemática em turmas do ensino médio, com grandes dificuldades na disciplina. $\mathrm{O}$ autor elaborou e aplicou uma sequência de atividades onde utilizou como estímulo inicial a projeção do filme Uma Mente Brilhante (Howard, 2001), para discussão em sala de aula. Em seguida, o pesquisador apresentou o Dilema do Prisioneiro, propondo sua realização como um jogo, aos alunos, introduzindo a ideia de Matriz de Payoff, procurando, assim, rever conteúdos já estudados, como "matrizes”, em uma aplicação concreta. Discutiu o conceito de estratégia dominante e finalizou a aplicação do jogo Barganha com Ultimato. Concluiu que o uso dessa teoria em sala de aula consiste em um elemento modificador do ensino de Matemática. Conforme o autor, "o objetivo de usar a introdução da teoria dos jogos como elemento motivador ao ensino da matemática no Ensino Médio é perfeitamente viável.” (p.54)

Santos (2016), em seu trabalho, propõe uma sequência de atividades com o objetivo de aplicar tópicos da Teoria da Probabilidade à Teoria dos Jogos para alunos do Ensino Médio. Tem como objetivos apresentar uma forma diferente e motivadora de tratar dos fundamentos da probabilidade e introduzir conceitos da Teoria dos Jogos. O autor propôs, inicialmente, o jogo Dilema do Prisioneiro e sua discussão por duplas de alunos. Foram introduzidos os conceitos de Matriz de Payoff, de jogos sequenciais, jogos envolvendo Teoria das Probabilidades e cálculo de ganho (payoff) em estratégias mistas. Foi proposto um jogo em que candidatos a um cargo executivo decidem se aceitam ou não doações financeiras. Dessa maneira, o pesquisador verificou que os alunos mostraram-se motivados com tal prática, bem como concluiu ser pertinente a busca por métodos de aproximação de teorias e aplicações do cotidiano dos estudantes.

Encontra-se também uma proposta de atividades para o Ensino Médio sobre a Teoria dos Jogos no trabalho de Feliciano (2007). O principal objetivo da pesquisa é o de investigar a possibilidade de introduzir a Teoria dos Jogos em sala de aula, como forma de motivação para a apresentação de uma aplicação da Matemática. A sequência foi composta das seguintes etapas: apresentação de breve relato histórico dessa teoria; definição de valor de utilidade e aplicação de exercício sobre preferências em relação às escolhas propostas; definição de estratégias puras e mistas e aplicação do jogo Par ou Ímpar em duplas, repetidas vezes; representação de pares de estratégias de um jogador e representação da Matriz de Payoff para o jogo Par ou Ímpar; definição de jogos de soma zero e de soma não zero; apresentação da resolução de um jogo dessa teoria, através de matrizes fornecidas; apresentação do jogo Dilema do Prisioneiro e proposta de atividades sobre aplicação dos conceitos estudados nesse jogo. 
As considerações de Feliciano (2007) deixam claro o interesse e empenho dos alunos nas atividades, mesmo alguns apresentando dificuldades com determinados conceitos dessa teoria, bem como com conteúdos e procedimentos matemáticos mais básicos. A pesquisadora concluiu que é possível apresentar a Teoria dos Jogos a alunos do Ensino Médio.

\begin{abstract}
Após a aplicação da sequência didática, percebemos que os alunos demonstraram maior interesse e empenho no estudo da Matemática. O estudo da Teoria dos Jogos desenvolveu, no aluno, um maior senso crítico, ajudando-os na tomada de decisão em situações da vida cotidiana, principalmente porque a Teoria dos Jogos tem como princípio básico utilizar conceitos matemáticos para analisar situações de interação entre indivíduos. Acreditamos que a Teoria dos Jogos pode ser ensinada no Ensino Médio, não como mais um instrumento utilizado para rever conteúdos, mas como um novo conceito, uma nova maneira de se ensinar Matemática, com o objetivo de desenvolver no aluno, o interesse pela Matemática e por tudo o que ela representa na construção do conhecimento. (FELICIANO, 2007, P.122)
\end{abstract}

Seguindo nas considerações acima, se faz coerente a aplicação de jogos e conceitos dessa teoria no ensino médio, a fim de desenvolver a habilidade de tomar decisões em situações desse tipo, que podem se apresentar ao indivíduo em sua vida. O trabalho apresentado nesta pesquisa norteia-se sob esse aspecto.

Uma vez que não há muitas pesquisas sobre aplicação da Teoria dos Jogos em sala de aula, justifica-se a contribuição da presente pesquisa.

O clássico Dilema do Prisioneiro, bem como outras situações-dilema, oferecem possibilidades de abordar a vida em sociedade, no que diz respeito à relação entre competição e cooperação e, sendo assim, abre margem à práticas educativas que podem ser formalizadas no âmbito da escola.

Investigar a utilização dos princípios básicos da Teoria dos Jogos, como forma de mobilizar nos alunos a habilidade de tomar decisões em situações estratégicas, apresentadas em forma de um jogo, torna-se coerente, visto que a sala de aula constitui um espaço de inovação e de transformação, bem como que a habilidade de tomar decisões é importante para o indivíduo em sociedade.

Contudo, para atingir o objetivo de trabalhar nos alunos a habilidade de tomar decisão em situações de jogos de conflito, este trabalho procurou despertar nos mesmos o envolvimento com atividades apresentadas em forma de situações-dilema em sala de aula, bem como a relação intrínseca entre cooperação e competição existente em situações desse tipo.

Uma sequência de atividades foi aplicada, durante sete aulas de matemática, em uma 
turma de $3^{\circ}$ Ano do Ensino Médio, de uma escola estadual em um município de São Paulo.

Foram abordados e analisados jogos clássicos dessa teoria em sala de aula, a fim de estimular a produção de outros jogos por parte dos alunos. Não se tratou de trabalhar a Teoria dos Jogos, mas sim de utilizar seus pressupostos para o desenvolvimento de estratégias em situações de conflito. 


\title{
CAPÍTULO 3
}

\section{METODOLOGIA DE PESQUISA}

\author{
"A estratégia torna as escolhas sobre o que \\ não fazer tão importantes quanto as escolhas \\ sobre o que fazer." (Michael Porter)
}

A metodologia de pesquisa adotada para o trabalho foi a Design Experimentt ${ }^{10}$, que consiste no planejamento e na aplicação de experimentos de ensino na área de Matemática com determinadas características, adequadas a esta pesquisa.

De acordo com Karrer (2006), esta metodologia surgiu nos Estados Unidos na década de 70 com objetivo de atender as necessidades específicas de pesquisas ligadas à Educação Matemática, que, até então, utilizavam metodologias de pesquisa de outras áreas. Desenvolvida na tentativa de preencher um espaço que existia entre a prática da pesquisa e a prática do ensino, a metodologia Design Experiment compreende o interesse do pesquisador nos processos de aprendizagem de determinado assunto: compreensões, trajetórias, dificuldades e avanços.

Segundo Cobb et al. (2003), dentro desta metodologia os experimentos de pesquisa são conduzidos para desenvolver teorias, não apenas para indicar empiricamente o que funciona ou não. As teorias são relativamente simples pois tem por objetivo pesquisar o processo de aprendizagem de um tema específico.

Para os autores trata-se de uma "ecologia de aprendizagem": termo que consiste em uma analogia entre o processo de aprendizagem e o significado da palavra "ecologia", pois resulta em um sistema complexo envolvendo vários elementos de diferentes tipos e níveis interagindo entre si. Tais elementos incluem as questões ou desafios propostos aos alunos, os diferentes tipos de intervenções, regras de participação estabelecidas, materiais utilizados e a atuação do professor "orquestrando" todos estes elementos.

Esta metodologia possibilita o professor atuar também como pesquisador, ou seja, permite que o professor realize experiências em sala de aula, sendo ele mesmo responsável pelo aprendizado. A não dissociação entre professor e pesquisador foi um dos principais

10 Foi mantido o termo em inglês, pois assim vem sendo utilizado em trabalhos na área de educação matemática no país. 
motivos da escolha desta metodologia para o desenvolvimento deste trabalho.

O Design Experiment tem como característica, testar e melhorar projetos educacionais, sendo os processos de aprendizagem, interpretados de forma ampla para abranger o conhecimento, a relevância da prática social, a evolução da aprendizagem, bem como a construção de identidades e interesses (COBB et al, 2003, p.10)

Uma pesquisa baseada na metodologia Design Experiment envolve a preparação de uma atividade didática: uma sucessão de procedimentos de ensino e um método de registro utilizado durante esses procedimentos, que são, cada um deles, analisado e utilizado na preparação do próximo.

Ao se preparar um experimento de ensino, busca-se responder as questões da pesquisa, Portanto, quando o experimento é aplicado, é possível a todo momento comparar a conjectura com os resultados obtidos, de forma a fazer ajustes para atingir os objetivos da pesquisa.

Karrer (2006), menciona que o foco dessa metodologia de pesquisa consiste no fato de que após cada aplicação de atividade de pesquisa, deve-se fazer uma análise, identificando quais modificações são necessárias para atingir o objetivo específico daquela atividade.

Dessa forma, uma importante característica do Design Experiment é possibilidade de intervenção, que tem por objetivo fazer aperfeiçoamentos nas atividades de um experimento, visando ajustá-lo de acordo com as questões de pesquisa.

Collins et al. (2004), afirmam que o Design Experiment representa um processo progressivo de aprimoramento da pesquisa, mediante os resultados observados durante sua aplicação, o que demanda revisão constante, para que os obstáculos observados possam ser minimizados: tem fundamento na premissa de uma avaliação contínua da prática. Portanto, o entendimento do fenômeno em investigação ocorre enquanto o experimento se desenvolve.

Nesse contexto, Biembengut e Hein (2003) recomendam a escolha desta metodologia ao considerarem que um processo deve ser avaliado constantemente para tornar-se um fator de redirecionamento do trabalho do professor ou pesquisador e que esta forma de avaliação visa a potencialização e aplicabilidade da prática, que irá permear e nortear o projeto de pesquisa.

Cabe ressaltar que dentro dessa metodologia de pesquisa, somente no momento em que se aplica o experimento é que se verifica a funcionalidade do mesmo para aquele contexto.

De acordo com Cobb et al. (2003), o caráter dinâmico e a natureza intervencionista do Design Experiment permitem o repensar das conjecturas iniciais através de uma abordagem interativa, possibilitando a elaboração de novas tarefas, bem como ultrapassando a relação 
professor-pesquisador, visto que dentro dessa metodologia não se diferencia os papéis de professor e de pesquisador.

Sendo assim, toda pesquisa realizada através da metodologia Design Experiments tem por objetivo desenvolver o entendimento sobre um conteúdo matemático particular, bem como investigar possibilidades de novas formas de aprendizagem. Entretanto, esse tipo de metodologia é recomendado para professor-pesquisador, pois este assume uma quebra consciente dessas atuações, bem como para um grupo restrito de estudantes, que são os colaboradores do processo. Não existe para a realização de Design Experiments, período de tempo definidos (horas, semanas ou períodos acadêmicos).

Contudo, Cobb et al. (2003) deixam claro aos pesquisadores que, ao adotarem o Design Experiment como metodologia, precisam ter claras as ideias e formas de raciocínio que constituem a aprendizagem que se objetiva desenvolver nos estudantes. Sendo assim, devem desenvolver conjecturas que identifiquem as capacidades atuais dos estudantes e outros recursos que eles podem estar aptos para construir, uma vez que o objetivo primordial de uma pesquisa com base nessa metodologia consiste em testar e revisar essas conjecturas.

Martins (2010) reforça que as atividades planejadas em pesquisas que adotam essa metodologia, não possuem caráter de atividade "pronta", uma vez que as mesmas podem ser modificadas durante o seu desenvolvimento, ou repensadas para um próximo momento, de acordo com as interações dos aprendizes.

Com base nessas considerações, existe nesta metodologia de pesquisa a preocupação do pesquisador a respeito do pensamento matemático dos estudantes, bem como de possíveis modificações desses pensamentos. Nesse sentido, o professor-pesquisador pode criar situações que encorajem os alunos a modificarem seus pensamentos usuais, uma vez que a finalidade deste tipo de metodologia está nas contribuições individuais dos estudantes; as ações do professor devem interagir com esse contexto.

Em resumo, e segundo Cobb et al. (2003), podem ser descritas cinco características básicas desta metodologia:

- Desenvolvimento de teorias com base nos processos de aprendizagem: a metodologia se volta para a compreensão de como as pessoas aprendem;

- Intervenção, para repensar a elaboração e realização de atividades: depois de cada atividade realizada, faz-se uma reflexão e reorganização da mesma;

- Aspectos prospectivo e reflexivo: o aspecto prospectivo tem a ver com o fato de que o experimento é implantado a partir de uma conjectura inicial; o aspecto reflexivo se justifica porque a partir das intervenções podem surgir novas conjecturas; 
- Processo cíclico que relaciona os aspectos prospectivo e reflexivo: aplicar a atividade, refletir sobre os resultados, reelaborar a atividade, aplicar outra atividade, e fazer tudo novamente, assim por diante;

- Obtenção dos aspectos teóricos a partir da prática: colocar uma teoria em questão, ou seja, verificar uma pergunta de pesquisa a partir de um experimento ajustável.

Convém acrescentar que existe uma relação intrínseca entre os aspectos reflexivo e cíclico. Dentro do aspecto reflexivo, analisa-se conjecturas realizadas, de modo que quando uma delas é descartada, novas conjecturas podem ser testadas; dentro do aspecto cíclico, por sua vez, permite-se que o experimento desenhado seja alterado frequentemente de acordo com as informações obtidas.

Ainda em relação ao aspecto cíclico, tem-se então um caráter espiral: atividade, aplicação da atividade, análise da atividade, design de nova atividade.

Sendo assim, escolheu-se o Design Experiment para responder as questões da presente pesquisa, que consistem em investigar como os alunos lidam com as situações de jogos de conflito e como essas situações trabalham a habilidade de tomar decisão. A escolha dessa metodologia justifica-se, em primeiro lugar, pelo fato da mesma ser apropriada quando o professor é também o pesquisador; em segundo lugar, pela possibilidade de modificação do experimento ao longo do processo.

Neste trabalho foi proposto a realização de um experimento de ensino que consistiu em abordar, sistematizar e propor a criação de situações de jogos de conflito, tendo como base o desenvolvimento da habilidade do aluno em lidar com esse tipo de situação que pode se apresentar em diversos momentos da vida. À medida que o experimento foi acontecendo, o mesmo pode ser reajustado de forma contínua .

Por ser baseada na metodologia Design Experiment, o experimento realizado foi desenhado, bem como composto de atividades que trabalharam e estimularam situações de jogo da referida teoria; isso justifica um caráter prospectivo.

Partindo da conjectura de que as situações de jogo despertam a necessidade de buscar estratégias de resolução (o que trabalha no aluno a habilidade de tomada de decisão), essa pesquisa oferece abertura para o surgimento de novas conjecturas durante a realização dessa sequência didática. Dessa forma, a pesquisa contém um caráter pragmático que oferece sugestões de como o mesmo pode ser adaptado a novas circunstâncias. Além disso, essa pesquisa deteve sua estrutura em função das produções dos participantes, apresentando um caráter reflexivo que permitiu uma reorganização contínua.

A sequência de atividades elaborada pela presente pesquisa consiste na apresentação, 
discussão e estímulo à criação de situações-dilema (próprias da Teoria dos Jogos), sob análise dos resultados em cada atividade, apresentando um caráter cíclico.

A professora-pesquisadora lançou mão de registros durante todo o experimento, no que tange aos processos de compreensão, tentativas de solução, bem como apreensão de sistemas de resoluções das situações de jogos, feitos pelos alunos.

Em consonância com o formato e com as características da metodologia Design Experiment, essa pesquisa consistiu, em sua realização, de três fases:

- Fase 1: elaboração das atividades e continuidade do processo de revisão bilbiográfica;

- Fase 2: implementação do experimento de ensino, com base na coleta de dados e implementação de intervenções necessárias, cujos dados também são coletados;

- Fase 3: análise dos dados antes e depois das intervenções e da necessidade de redesign das atividades.

$\mathrm{O}$ foco da pesquisadora no presente experimento tem a ver com a forma de pensar dos alunos sobre os jogos-dilema, tanto no âmbito da criação, quanto no ato de jogar, quanto ao posicionamento e à argumentação.

A elaboração das atividades foi pensada pela pesquisadora de modo a antecipar a maneira como os alunos poderiam receber os jogos, bem como seu posicionamento em relação ao dilema proposto.

A maneira de intervir durante as etapas desse experimento foi programada e, dessa forma, permitiu aberturas para adaptações que se fizeram convenientes no decorrer do mesmo.

Sendo assim, cada atividade sobre os jogos dessa teoria foi elaborada, aplicada e analisada, podendo também ser redesenhada visando melhorias, se for o caso, para uma próxima aplicação. 


\section{CAPÍTULO 4}

\section{O EXPERIMENTO}

"Tomar decisões urgentes e imediatas é como um jogo de certo e errado, não há meio termo." (Walmir Celso Koppe)

O presente capítulo contém a descrição do experimento de ensino elaborado com base na Teoria dos Jogos, que foi realizado com uma classe de $3^{\mathrm{a}}$ série do Ensino Médio, em uma escola pública da Grande São Paulo, no município de Carapicuíba, CohabII, durante as aulas regulares.

\subsection{OS ALUNOS E A ESCOLA}

Localizada em um conjunto habitacional, a escola é da rede estadual, ofertando Ensino Fundamental II e Médio, com funcionamento nos períodos da manhã e da tarde, com seis aulas diárias.

O Projeto Político Pedagógico da escola é elaborado por toda a comunidade escolar e é atualizado anualmente. Este é apresentado aos pais, professores, alunos, funcionários através de reuniões e encontros. Cabe ressaltar que a escola oferece aos professores total abertura a inclusão de diferentes propostas de ensino, incentivando a realização dos mesmos.

A comunidade que frequenta a escola é de classe média-baixa. Com um total de 1600 alunos, a escola apresentou no último ano (2017), nota no IDESP (Índice de Desenvolvimento da Educação do Estado de São Paulo) igual a 2,57 no Ensino Médio, sendo a nota média da Diretoria à qual a escola pertence igual a 2,05, bem como a nota média do Estado igual a 2,36; no SARESP (Sistema de Avaliação de Rendimento Escolar do Estado de São Paulo), a escola apresentou percentual de alunos no nível básico em Matemática no Ensino Médio igual a 52,2, sendo o percentual médio da Diretoria igual a 43,3 e do Estado igual a 48,7.

O experimento foi realizado numa turma do $3^{\mathrm{a}}$ série do Ensino Médio composta por 35 alunos, com idades entre 16 e 17 anos. Os alunos desta turma apresentam, em geral, um bom rendimento em relação a aprendizagem, conseguindo boas notas na grande maioria das 
disciplinas; são muito entrosados e gostam de realizar atividades em grupo, bem como de auxiliar uns aos outros participar.

Os alunos são, em geral, assíduos e compreendem e atendem as normas estabelecidas pela escola e pelos professores, exigindo dos colegas a mesma atitude. Por serem alunos de periferia, a escola muitas vezes é o local de encontro desses jovens, o que é típico da idade. A maioria das famílias desses alunos participa ativamente das reuniões realizadas, interessandose pelo rendimento dos mesmos.

A professora-pesquisadora leciona nessa escola há mais de dez anos e é professora dessa turma, tendo ministrado aula para esses mesmos alunos quando estes estavam no $7^{\circ}$ ano do Ensino Fundamental e também no $1^{\circ}$ ano do Ensino Médio. Sendo assim, detêm uma boa relação com os mesmos, conhecendo suas dificuldades e capacidades.

Nas aulas em que foram realizadas as atividades do experimento, quase todos os alunos estiveram presentes e a turma foi bastante participativa.

\subsection{DESCRIÇÃO DO EXPERIMENTO}

O experimento foi composto por três etapas e ao todo foram utilizadas sete aulas com duração de 50 minutos para a realização das várias atividades.

A primeira etapa consistiu no entendimento e identificação, por parte dos alunos, de situações de conflito e de possíveis estratégias para lidar com as mesmas. Na segunda etapa foi apresentado aos alunos os conceitos básicos da Teoria dos Jogos, através da sistematização das situações de jogos apresentadas, feita pela professora-pesquisadora. Na terceira etapa foi proposto que os alunos criassem situações de jogos, baseando-se no que foi visto e discutido na etapa anterior, que foram apresentadas e analisadas.

Os alunos foram organizados em nove grupos de 3, 4 ou 5 alunos, formados de maneira voluntária, que se mantiveram iguais em todas as atividades das três etapas do experimento.

Todas as etapas foram acompanhadas de registros e relatórios, por parte da professorapesquisadora, bem como do registro das respostas, por parte dos alunos. O experimento também contou com a observação de uma outra professora de matemática da unidade, que esteve presente na sala em todas as etapas, colaborando com registros para a pesquisa.

Os objetivos e duração de cada etapa estão descritos com detalhes a seguir. 


\subsubsection{PRIMEIRA ETAPA}

Esta etapa do experimento compreendeu três aulas semanais. O seu principal objetivo foi trabalhar situações de jogos de conflito, procurando despertar a necessidade de busca por estratégias de resolução.

A primeira aula foi composta de duas atividades em folhas impressas, entregues para cada grupo, com o objetivo de sensibilizar os alunos para a existência de situações de jogos de conflito.

Ao receberem as atividades descritas, os grupos começaram a ler prontamente e depois, passaram a registrar suas conclusões. As folhas com as respostas foram entregues para a professora-pesquisadora, que foram utilizadas para análise.

Na Atividade 1 foi apresentado o texto do Dilema do Prisioneiro, como sendo uma situação de conflito, sem ser denominada jogo (ver original nos Anexos). O texto foi seguido de duas questões sobre a opinião dos grupos em relação ao dilema proposto.

Atividade 1 - Leiam o texto a seguir e respondam as questões:

Dois homens cometeram um crime juntos e foram capturados. Eles estão presos em celas separadas e sem comunicação entre eles. Ambos serão interrogados separadamente e receberão a seguinte proposta: se os dois negarem o crime, serão condenados a 1 ano de prisão; se os dois confessarem, serão condenados a 5 anos; se um confessar e o outro negar, o que confessou será libertado e o outro será condenado a 10 anos de prisão. No entanto, um não poderá saber a resposta que o outro dará.

1- Na opinião de vocês, cada prisioneiro ao ser chamado deve confessar ou não? Por que?

2 Após a discussão da questão 1 , descrevam todas as possibilidades que pode acontecer com os prisioneiros. O que vocês concluem então?

Dois grupos concluíram que os prisioneiros não deveriam confessar:

1- $\mathrm{Na}$ opinião de vocês, cada prisioneiro ao ser chamado deve confessar ou não? Por que?

Qu nusar epiniäe: eles denem negar s crime

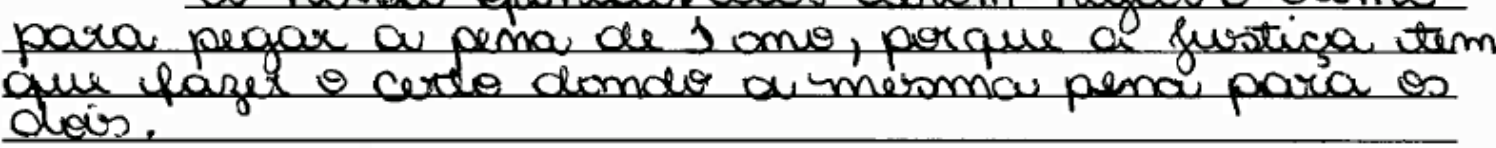

E justificaram com base no que acreditaram ser o desfecho da situação:

2- Após a discussão da questão 1, descrevam todas as possibilidades que podé acontecer com os prisioneiros. O que vocês concluem então?

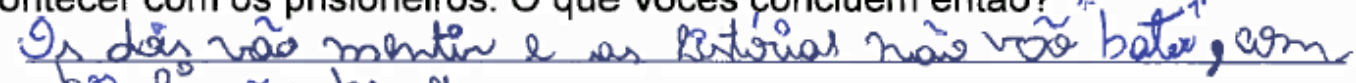
ino, vambos ficaño previs. 
Todos os outros grupos escolheram "confessar" como sendo a melhor opção:

1- Na opinião de vocês, cada prisioneiro ao ser chamado deve confessar ou não? Por que?

Co receble a proposta de que ae um conpenan norá

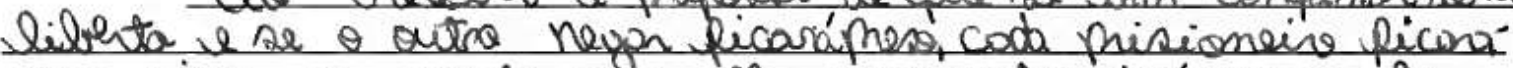
com ins em mente, e a achon que outro ina' negor, ele

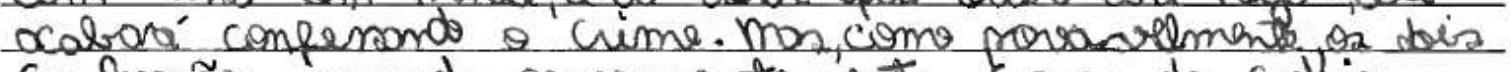
confemón pregond comequentemente, 5 omes de codlia.

Dentre esses grupos, um deles citou a questão da consequência dos próprios atos:

1- $\mathrm{Na}$ opinião de vocês, cada prisioneiro ao ser chamado deve confessar ou não? Por que?

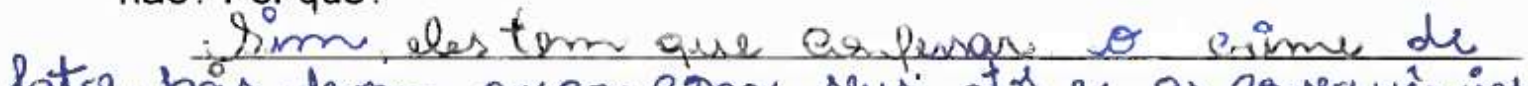
loto, pois dram ancar com seus atos e os conrequémisas,

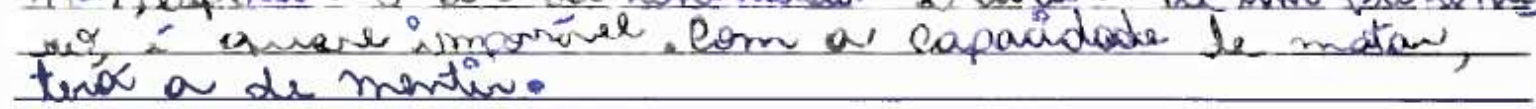

Um outro grupo que escolheu a opção "confessar", mencionou a questão de se ter a consciência tranquila:

1- Na opinião de vocês, cada prisioneiro ao ser chamado deve confessar ou não? Por que?

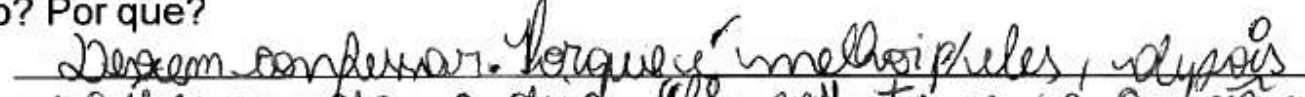

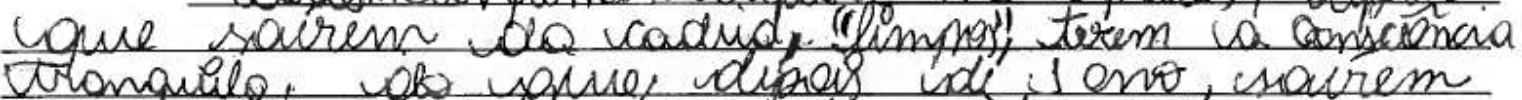

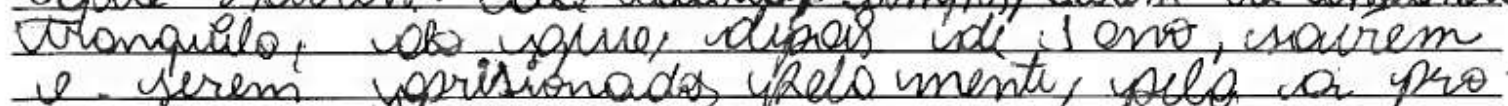
e serem verisionads ypelo mente yole ar proprua conctencia.

Os grupos tiveram facilidade em descrever as possibilidades da situação proposta:

2- Após a discussão da questão 1, descrevam todas as possibilidades que pode acontecer com os prisioneiros. O que vocês concluem então? Existem quatio possibledadef: for dour megarem;

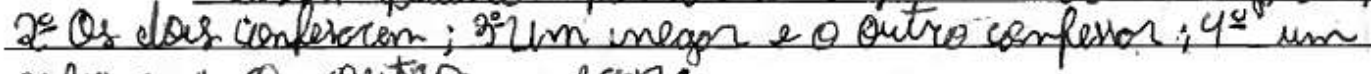
copessos i $Q$ outio meger

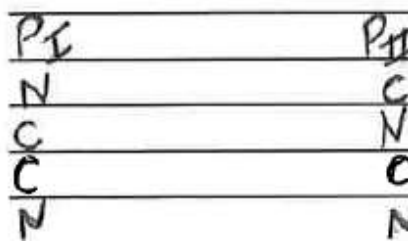


Outro grupo que escolheu "confessar" como melhor opção para os prisioneiros, focou o desfecho da situação na questão da fidelidade:

2- Após a discussão da questão 1 , descrevam todas as possibilidades que pode acontecer com os prisioneiros. O que vocês concluem então?

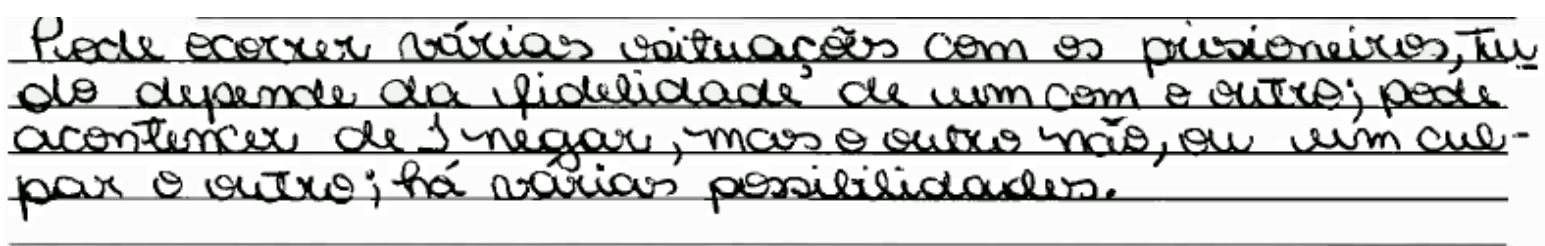

Em seguida, na Atividade 2, foi a vez de apresentar o texto do jogo Sete e Meio, seguido de duas perguntas sobre a escolha que os jogadores deveriam fazer, na opinião dos grupos.

Atividade 2 - Leiam o texto a seguir e respondam as questões:

Em 2002, Silvio Santos lançou o seguinte jogo: várias pessoas respondiam perguntas e à medida que acertavam permaneciam no jogo, até restarem duas (as que acertavam todas as perguntas). Essas duas eram os jogadores que deveriam escolher entre as cartas "Sete" $e$ "Meio".

Se os dois participantes escolhessem "Meio", dividiam um prêmio em dinheiro; se um escolhesse "Sete" e outro "Meio", o que tivesse escolhido "Sete" ganhava todo o prêmio sozinho; se os dois escolhessem "Sete", nenhum ganhava. estratégia.

No jogo os jogadores podiam se comunicar antes de escolher, tentando combinar uma jogador.

1. Descrevam todas as possibilidades e os respectivos ganhos ou perdas de cada

2. Na opinião de vocês, o que os jogadores devem combinar para obter o melhor ganho? Por que?

Os grupos foram unânimes em escolher "meio" como melhor opção para os jogadores:

1- Descrevam todas as possibilidades e os respectivos ganhos ou perdas de cada jogador.

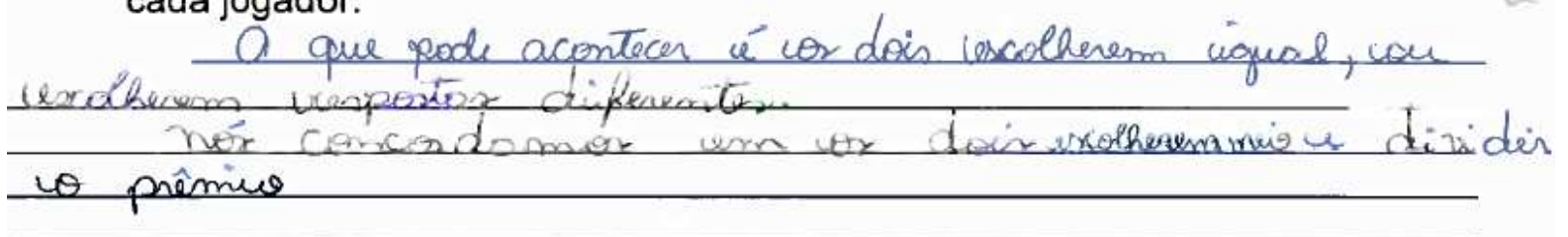


Um dos grupos citou a questão do caráter entre os participantes:

2- Na opinião de vocēs, o que os jogadores devem combinar para obter o

melhor ganho? Por que?
Us dos deviem uscoller wneio, fara

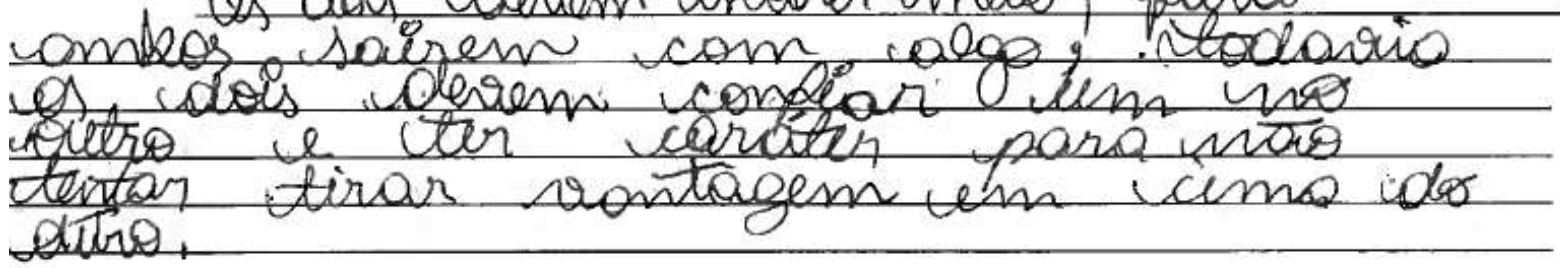

Outro grupo questionou a possibilidade dos jogadores escolherem "sete":

1- Descrevam todas as possibilidades e os respectivos ganhos ou perdas de cada jogador.

Gs dois podem user humildes U dividin $\theta$ denheiro.

teles podem combinar de dizen "meio" mas clegen na hono de repponder. um jocader train o oitho e dizen "sete" só para

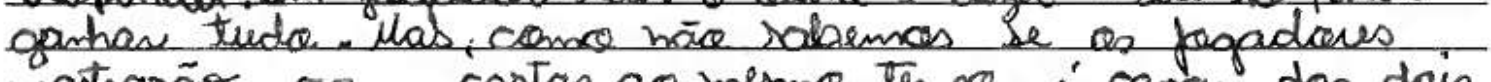
mastrarão as cortas aco menmo tempa, is capery dos dais excoshulum a oanta "sete" e perder tudo.

De maneira geral, todos os grupos foram capazes de descrever todas as possibilidades do jogo:

1- Descrevam todas as possibilidades e os respectivos ganhos ou perdas de cada jogador.

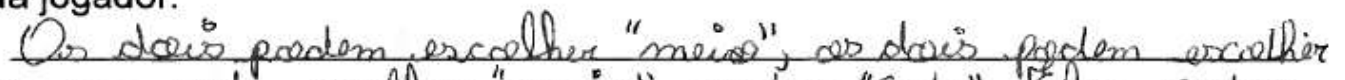
"Sete" ou um poede ercolher "meioe" e centeco "Sete". Eles pordem

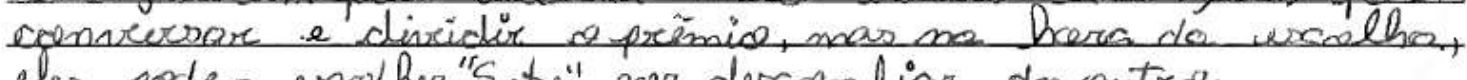
eles poden excolher "Sate" peer dercenfiar do coutede.

No entanto, os grupos focaram na combinação e na confiança entre os dois participantes:

2- Na opinião de vocês, o que os jogadores devem combinar para obter o melhor ganho? Por que?

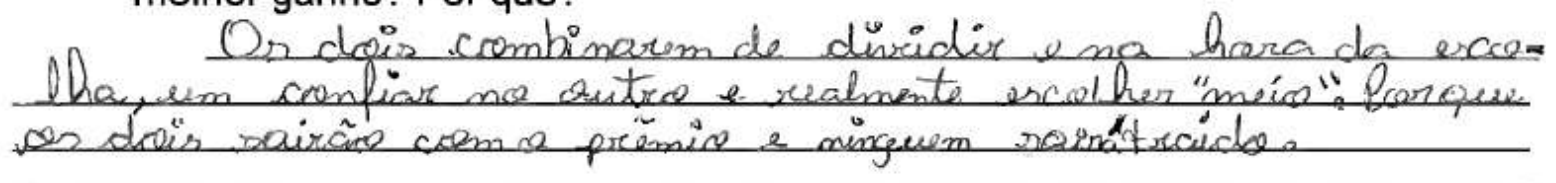

Na segunda aula, que foi aula-dupla (1 hora e 40 minutos), a professora-pesquisadora organizou uma plenária na sala de aula. Os objetivos da plenária foi o de estimular os alunos a 
exporem suas conclusões sobre as situações de jogo apresentadas na primeira aula e conduzir a compreensão dos alunos sobre essas situações.

Os grupos foram incentivados a expor suas conclusões registradas sobre os dois jogos. Um integrante de cada grupo fez essa exposição representando as conclusões do grupo, no tempo máximo de 5 (cinco) minutos cada. Durante cada exposição, os demais alunos ouviram atentamente, sem interromper. Os pareceres dados foram sucintos: alguns explicaram seu pensamento, outros simplesmente leram as conclusões registradas nas folhas.

Logo após todas as exposições, a professora-pesquisadora separou os grupos em dois lados da sala, ficando de um lado os três grupos que escolheram na Atividade 1 a opção "negar", e do outro os seis grupos que escolheram a opção "confessar", propondo que algum integrante desses grupos, de cada lado, tentasse convencer os outros alunos que tiveram conclusões diferentes de que sua escolha é a correta, com base na argumentação.

Depois, a professora-pesquisadora fez a condução das discussões registradas pelos grupos, rumo ao entendimento da melhor resposta das situações de jogos Dilema do Prisioneiro e Sete e Meio, esquematizando todas as possibilidades e consequências, com a participação dos alunos, oralmente.

A professora-pesquisadora realizou então uma breve conclusão das duas situaçõesproblema. A mesma começou com a seguinte colocação: “vamos montar pares de escolhas para a situação 1, colocando na primeira posição a escolha do prisioneiro A e na segunda a escolha do B e ver as consequências para ele”.

O esquema abaixo foi escrito na lousa pela professora-pesquisadora, de modo que a grande maioria dos alunos ditaram juntos as respostas, de maneira bastante participativa:

$$
\begin{aligned}
& \text { (Confessar, Confessar) } \rightarrow 5 \text { anos } \\
& \text { (Confessar, Negar) } \rightarrow 0 \text { anos } \\
& \text { (Negar, Confessar) } \rightarrow 10 \text { anos } \\
& \text { (Negar, Negar) } \rightarrow 1 \text { ano }
\end{aligned}
$$

A professora-pesquisadora fez então a seguinte constatação, conduzindo os alunos à compreensão de uma solução: "Confessando, o prisioneiro A fica preso 5 ou 0 anos. Negando, ele fica preso 10 ou 1 ano. Vejamos: ficar preso nenhum ano é melhor do que 1; ficar preso 5 anos é melhor do que 10. Então é melhor confessar. O mesmo ocorre, do ponto de vista do prisioneiro B.",

Da mesma forma, a professora-pesquisadora escreveu, na lousa, outros pares de escolhas para a situação 2, colocando na primeira posição a escolha do jogador $\mathrm{A}$ e o resultado dessa escolha para A: 
(Meio, Meio) $\rightarrow$ metade

(Meio, Sete) $\rightarrow$ nada

(Sete, Meio) $\rightarrow$ tudo

$($ Sete, Sete) $\rightarrow$ nada

Para concluir disse aos alunos que "Obter tudo ou metade é melhor do que nada, então escolher "Sete" é melhor".

Uma das alunas exclamou que foi possível entender claramente.

Na sequência, um texto impresso sobre o jogo de baralho de cartas Le Her foi entregue a cada grupo, na forma de lição de casa. O texto foi seguido de questões sobre quando cada jogador deveria trocar, bem como sobre as diferenças entre esse jogo e dois jogos anteriores (Dilema do Prisioneiro e Sete e Meio).

\section{Lição de casa}

Vamos conhecer um jogo de cartas, chamado Le Her. Toma-se um baralhos comum, composto de 13 cartas: Ás, cartas numeradas de 2 até 10; um Valete, Dama e Rei. Dois jogadores pegam uma carta cada um, sem mostrá-la para o outro, e colocam uma terceira na mesa, sem vê-la. Eles decidem quem joga primeiro. O jogador 1 deve decidir se mantém a sua carta ou a troca com a carta do jogador 2, que não pode se recusar a fazer a troca. Depois, o jogador 2 deve decidir se mantém a sua carta ou a troca com a carta da mesa. Ganha quem tiver a carta de maior valor, dentre as três.

Jogue esse jogo.

1. Em quais circunstâncias o primeiro jogador deveria trocar?

2. E o segundo jogador, quando deveria trocar?

3. Quais as semelhanças e diferenças deste jogo em relação aos anteriores (Dilema do Prisioneiro e Sete e Meio)?

Todos os grupos, de maneira geral, tiveram opiniões parecidas sobre quando os jogadores devem trocar de carta:

1. Em quais circunstâncias o primeiro jogador deveria trocar?

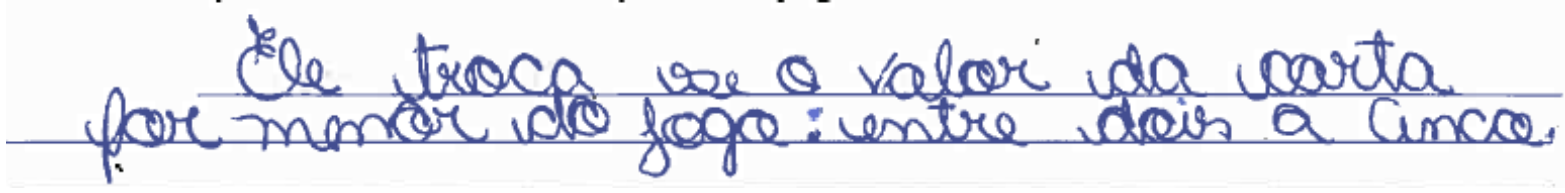

Dois grupos mencionaram a possibilidade do blefe nesse tipo de jogo.

1. Em quais circunstâncias o primeiro jogador deveria trocar?

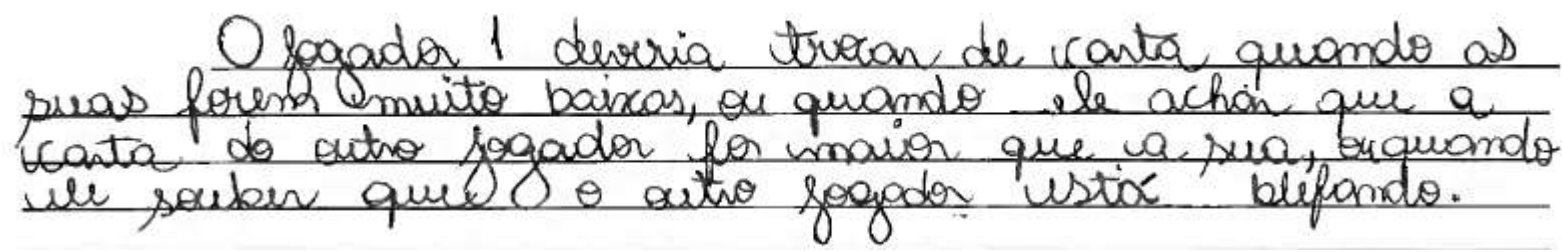


As opiniões também foram parecidas a respeito do segundo jogador.

2. E o segundo jogador, quando deveria trocar?

Q partix do troca, use Q vaegunda. fogadox olcar com a carta de nalor menor, se deveria trocar com mesa, coose contra.rio nace.

Somente um grupo compreendeu o papel do segundo jogador:

2. E o segundo jogador, quando deveria trocar?

Caso a Canta, inicial dele fon de baixo vabre e

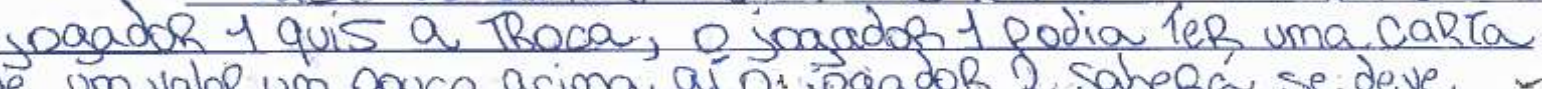
de um valorum poucr acima, á, or jogadoR 2 Saberá se deve continuar com a carta o. irócar pela da mesa para lentar uma maich.

Sobre as diferenças e semelhanças do Le Her com o Dilema do Prisioneiro e com o Sete e Meio, as opiniões foram diversas. Um grupo respondeu:

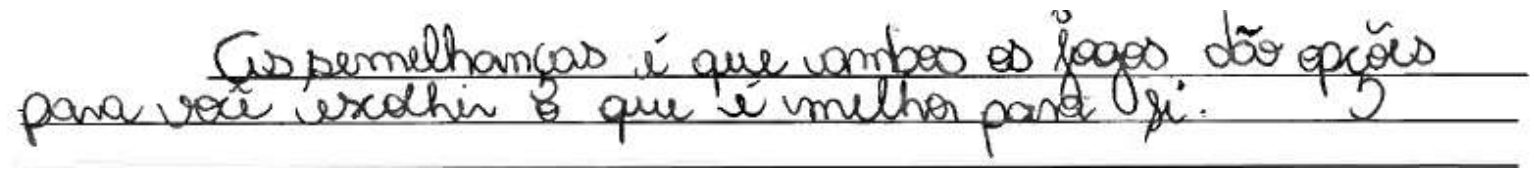

Houve também um grupo que respondeu:

3. Quais as semelhanças e diferenças deste jogo em relação aos anteriores (Dilema do Prisioneiro e Sete e Meio)?

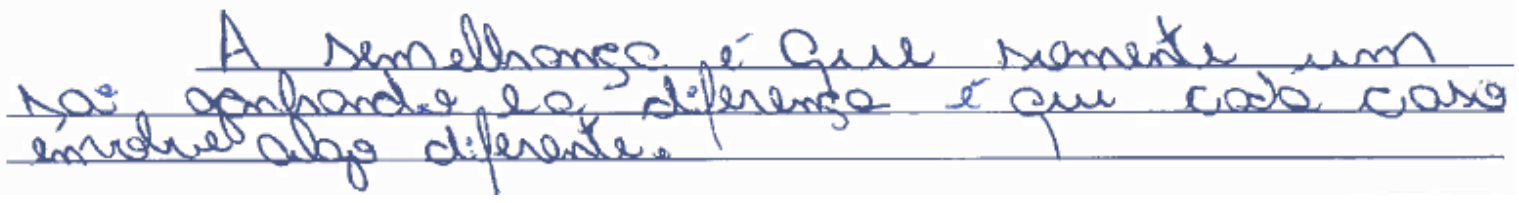

Na terceira aula, foi projetada uma cena do filme Uma Mente Brilhante (Howard, 2001), com o objetivo de questionar a cooperação, enquanto estratégia, para situações de jogo de conflito. A cena que se passa em um bar, onde amigos disputam entre si a conquista de uma jovem atraente. Na cena, a personagem John Nash percebe que se todos investirem nessa conquista, todos anulam suas chances com a moça e, consequentemente, com todas as outras moças. Porém, se nenhum deles investir na conquista dessa jovem, cada um poderá conquistar uma moça diferente. 
Após a projeção foi realizada outra atividade em grupo (Atividade 3), contendo interrogações sobre a estratégia mostrada na cena, bem como sobre as semelhanças entre a situação apresentada e as situações de jogos trabalhadas anteriormente.

Atividade 3. Respondam essas questões seguintes:

1. Sobre a cena do filme Uma Mente Brilhante (Howard, 2001): qual foi a estratégia que o personagem usou para ninguém "sair" sozinho?

2. Sobre a situação apresentada na cena, o que há de semelhante e de diferente com as outras situações trabalhadas anteriormente?

Todos os grupos identificaram a estratégia usada pelo personagem da cena:

1- Sobre a cena do filme Uma Mente Brilhante: qual foi a estratégia que o personagem usou para ninguém "sair" sozinho?

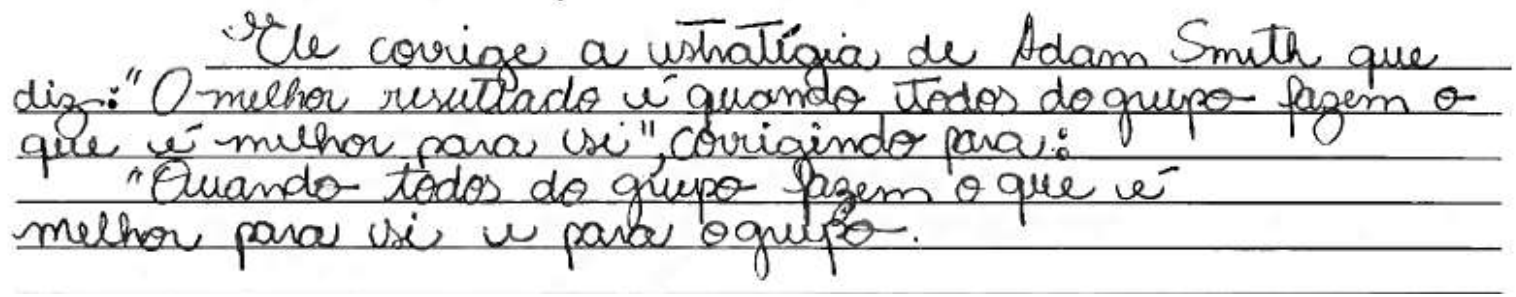

Um grupo que tentou justificar a estratégia de acordo com o que pensaram em relação aos envolvidos na cena:

1- Sobre a cena do filme Uma Mente Brilhante: qual foi a estratégia que o personagem usou para ninguém "sair" sozinho?

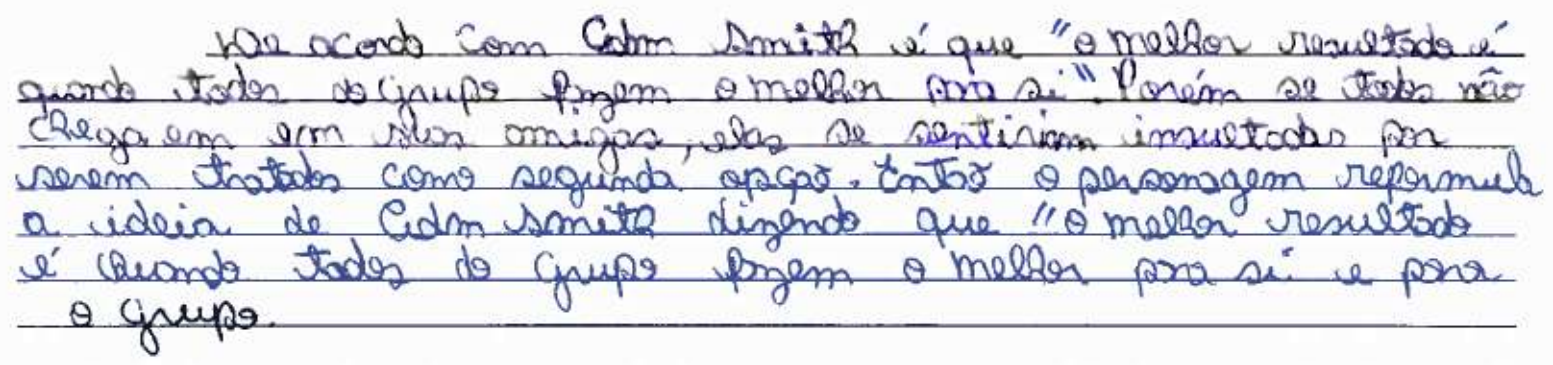

Em relação às semelhanças entre a situação da cena com a situação trabalhadas nas atividades anteriores, um grupo respondeu o seguinte:

2- Sobre a situação apresentada na cena, o que há de semelhante e de diferente com as outras situações trabalhadas anteriormente?

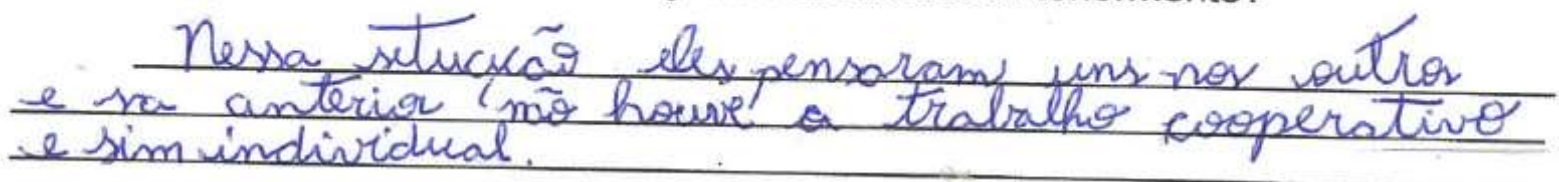


Outro grupo mencionou a questão do companheirismo e fidelidade entre os personagens da cena:

2- Sobre a situação apresentada na cena, o que há de semelhante e de diferente com as outras situações trabalhadas anteriormente?

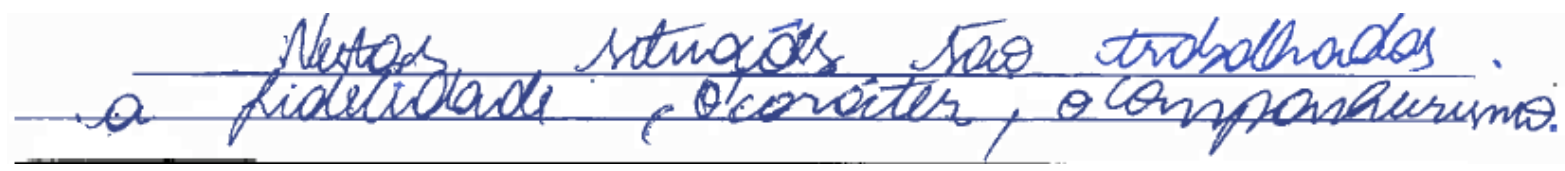

Um outro grupo citou o termo "Tomada de decisão":

2- Sobre a situação apresentada na cena, o que há de semelhante e de diferente com as outras situaçōes trabalhadas anteriormente?

le semeloranga lé que:sempre hoverá a resultado onde

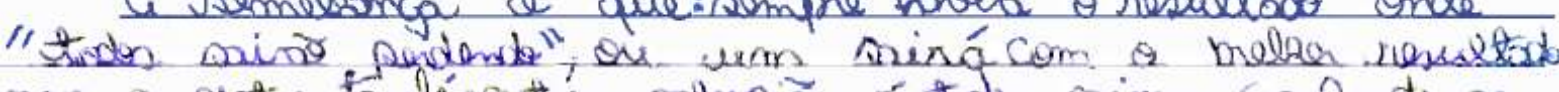

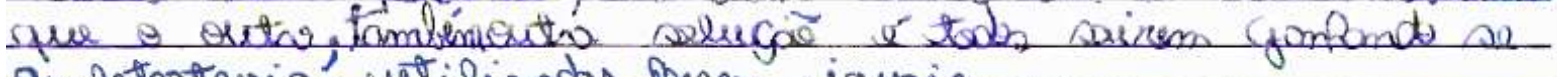
as intrategia's utilizadas prem iguais.

¿ diperenga esto que, nos duas iétimas situageés hó chonces de eema combrimasas, diperente da primeira.

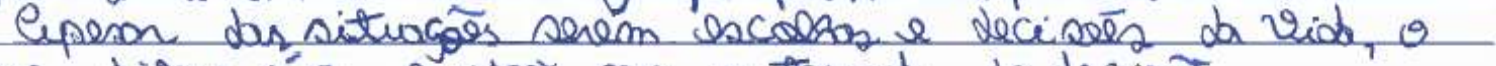

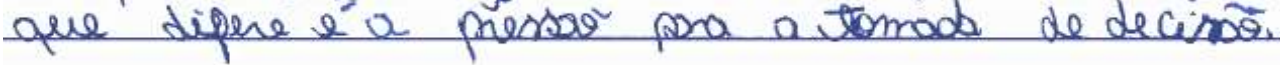

\subsubsection{SEGUNDA ETAPA}

O objetivo desta etapa foi realizar a sistematização de situações-dilema, com base em definições fundamentais da Teoria dos Jogos. Para esta etapa foi reservada uma aula.

A quarta aula então, consistiu em uma aula expositiva, que objetivou mostrar aos alunos uma nova aplicação da matemática. Durante essa aula ocorreu:

- Explanação sobre a existência de uma teoria matemática que estuda situações que foram trabalhadas nas atividades: Teoria dos Jogos, como uma teoria de modelos matemáticos que estuda escolhas ótimas para situações de conflito.

- Esclarecimento sobre o que é um jogo, ou seja, uma situação que envolve dois ou mais agentes (jogadores), onde cada decisão tomada por um, interfere nas decisões tomadas pelo outro e onde cada jogador só joga se existe a possibilidade de ter algum ganho.

- Abordagem do fato do personagem visto na cena do filme Uma Mente Brilhante (Howard, 2001) tratar-se de John Nash, um matemático que contribuiu muito para essa teoria, ganhando o prêmio Nobel de economia em 1994.

- Explicação sobre a divisão dos jogos em dois tipos: Cooperativos e Competitivos; menção sobre o fato da situação descrita na cena do filme Uma Mente Brilhante 
(Howard, 2001), ser um Jogo Cooperativo, enquanto que as situações trabalhadas anteriormente serem Jogos Competitivos. Outro exemplo citado foi de uma partida de futebol.

- Colocação de que dentro dos jogos Competitivos existirem Jogos de Soma Zero; (dado como exemplo o jogo: "par ou ímpar") e Jogos de Soma Não Zero (dado como exemplo o jogo "batalha dos países").

- Explanação sobre a situação da Atividade 1 chamar-se Dilema do Prisioneiro, bastante conhecido, e o jogo da Atividade 2 chamar-se Sete e Meio, bem conhecido por um programa de televisão. E que são ambos exemplos de jogos de Soma Não Zero; menção que o jogo Le Her é um exemplo de um jogo de Soma Zero.

- Construção na lousa, de uma Matriz Payoff para o Dilema do Prisioneiro e menção de que a palavra payoff significa "ganho", a fim de que os alunos pudessem perceber que, através da mesma torna-se possível analisar a melhor solução para um jogo. Discutindo também como que em situações de jogos de conflito é sempre possível obter "solução", ou seja, uma possibilidade de ambos os jogadores fazerem escolhas que são melhores para ambos, ao mesmo tempo.

- Identificação, na matriz apresentada, do perfil (Confessar, confessar) como sendo a solução do jogo.

Cada aluno recebeu uma folha impressa contendo um breve resumo dos conceitos abordados durante a aula expositiva, em forma de um texto intitulado "Uma nova teoria".

\section{UMA NOVA TEORIA}

Leiam atentamente o texto seguinte:

Existe uma teoria matemática que estuda situações como as que trabalhamos:

\section{Teoria dos Jogos.}

Trata-se de uma teoria de modelos matemáticos que estuda escolhas ótimas para situações de conflito.

Um jogo é qualquer situação que envolva dois ou mais agentes (jogadores), onde cada decisão tomada por um, interfere nas decisões tomadas pelo outro; cada jogador só joga se existe a possibilidade de ter algum ganho.

O personagem visto na cena do filme "Uma Mente Briljante" trata-se de Jonh Nash, um matemático que contribuiu muito para essa teoria, ganhando o prêmio Nobel de economia em 1994.

Os jogos se dividem em dois tipos: Cooperativos (os jogadores buscam uma maneira de todos ganharem) e Competitivos (cada jogador procura ganhar dos outros)

A situação descrita na cena do filme Uma Mente Brilhante é um Jogo Cooperativo, enquanto que as situações trabalhadas anteriormente são Jogos Competitivos.

Dentro dos jogos Competitivos tem-se: Jogos de Soma Zero (para um jogador ganhar, o outro tem que perder. Exemplo: “par ou impar”) e Jogos de Soma Não Zero (pode 
haver um beneficio para ambos. Exemplo: “dois ou um”).

A situação da atividade 1 chama-se "Dilema do Prisioneiro" e a situação da atividade 2 chama-se "Sete e Meio". Ambas são denominadas Jogos de Soma Não Zero.

A situação da atividade para casa cham-se "Le Her" e trata-se de um Jogo de Soma Zero.

Observem essa maneira de representar Jogos Competitivos (Tempo previsto: 5 min). Chama-se Matriz de Payoff (A palavra payoff significa ganho):

\begin{tabular}{|c|c|c|c|}
\hline & & \multicolumn{2}{|c|}{ PRISIONEIRO B } \\
\hline & & Confessar & Negar \\
\hline \multirow[t]{2}{*}{ PRISIONEIRO A } & Confessar & $(-5,-5)$ & $(0,-10)$ \\
\hline & Negar & $(-10,0)$ & $(-1,-1)$ \\
\hline
\end{tabular}

Nas situações de jogos de conflito sempre existe uma "solução", ou seja, uma possiblidade de ambos os jogadores fazerem as escolhas que são melhores para ambos, ao mesmo tempo. No caso da Matriz apresentada, (Confessar, confessar) é a solução do jogo.

Após todas as explanações, a professora-pesquisadora solicitou aos alunos que comentassem oralmente sobre suas impressões a respeito dessa teoria. Alguns alunos se manifestaram dizendo que acharam a teoria muito interessante, que a mesma se torna atrativa por lidar com estratégias, que ela é importante porque busca solucionar dilemas e que já tinham ouvido falar em John Nash, entre outros comentários.

Em seguida, foi proposto aos grupos a realização da Atividade 4, que consistiu em propor aos grupos a representação da Matriz de Payoff do jogo "Sete e Meio", bem como a indicação da solução do jogo nessa matriz.

Atividade 4. Represente a Matriz de Payoff do jogo "Sete e Meio"

Indique a Solução:

Nenhum dos grupos demonstrou dificuldade em fazer a Matriz Payoff:

Atividade 4.Represente a Matriz de Payoff do jogo "Sete e Meio"

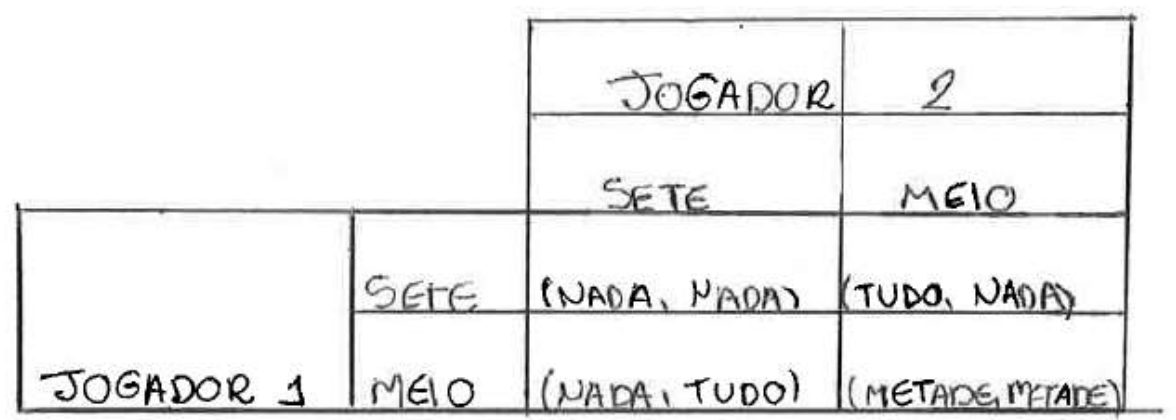


Indique a Solução:

\section{Os dois participantes devm uscoller meio e duvidir a prêmio}

No entanto, alguns alunos perguntaram sobre o valor do prêmio oferecido na situação do jogo, para ser descrito na matriz. A professora-pesquisadora respondeu que isso deveria ficar a critério de cada grupo. Houve um grupo que representou assim:

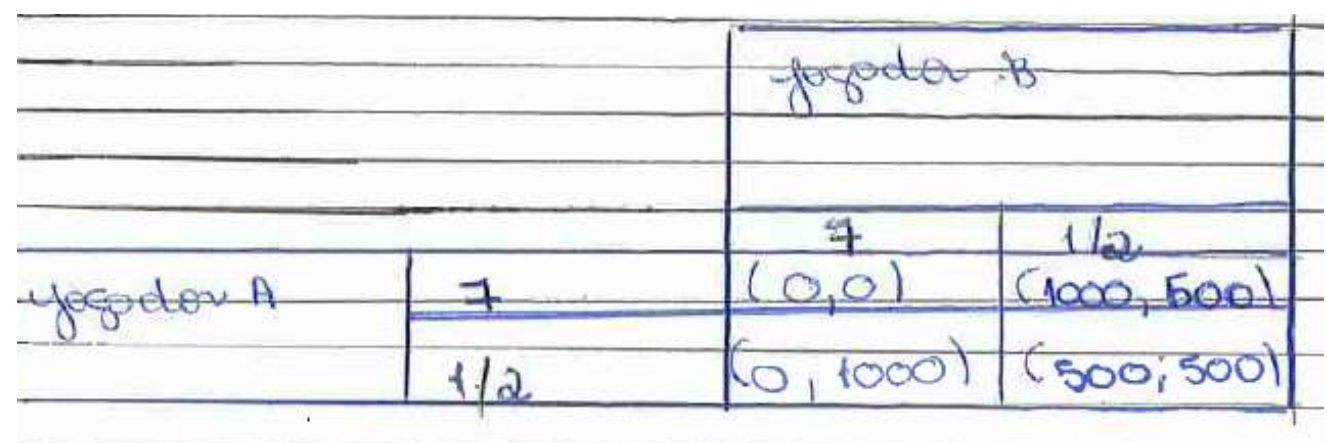

\subsubsection{TERCEIRA ETAPA}

A terceira etapa foi constituída de três aulas e teve por objetivo incentivar os alunos a criar situações de jogos em qualquer contexto dos mais variados e analisá-los a luz da Teoria dos Jogos.

Na quinta aula, cujo objetivo foi formular a descrição de um jogo de conflito, cada grupo recebeu uma folha com a proposta de elaboração dessa situação.

Atividade 5 - Criem uma situação de jogo de conflito com dois jogadores. Digam se o jogo é: Cooperativo ou Competitivo. Se for Competitivo, diga se é de Soma Zero ou de Soma Não Zero.

A professora-pesquisadora recolheu e analisou as criações dos grupos, para a preparação da aula seguinte.

Vários grupos demonstraram dificuldade em concatenar ideias para a criação de uma situação de jogo. Os mesmos solicitaram constantemente a orientação da professorapesquisadora para sua formulação.

Os grupos criaram situações como as seguintes: 
1. Criem uma situação de jogo de conflito com dois jogadores. Digam se o jogo é: Cooperativo ou Competitivo. Se for Competitivo, diga se é de Soma Zero ou de Soma Não Zero.

\section{Turocar ou nãr?}

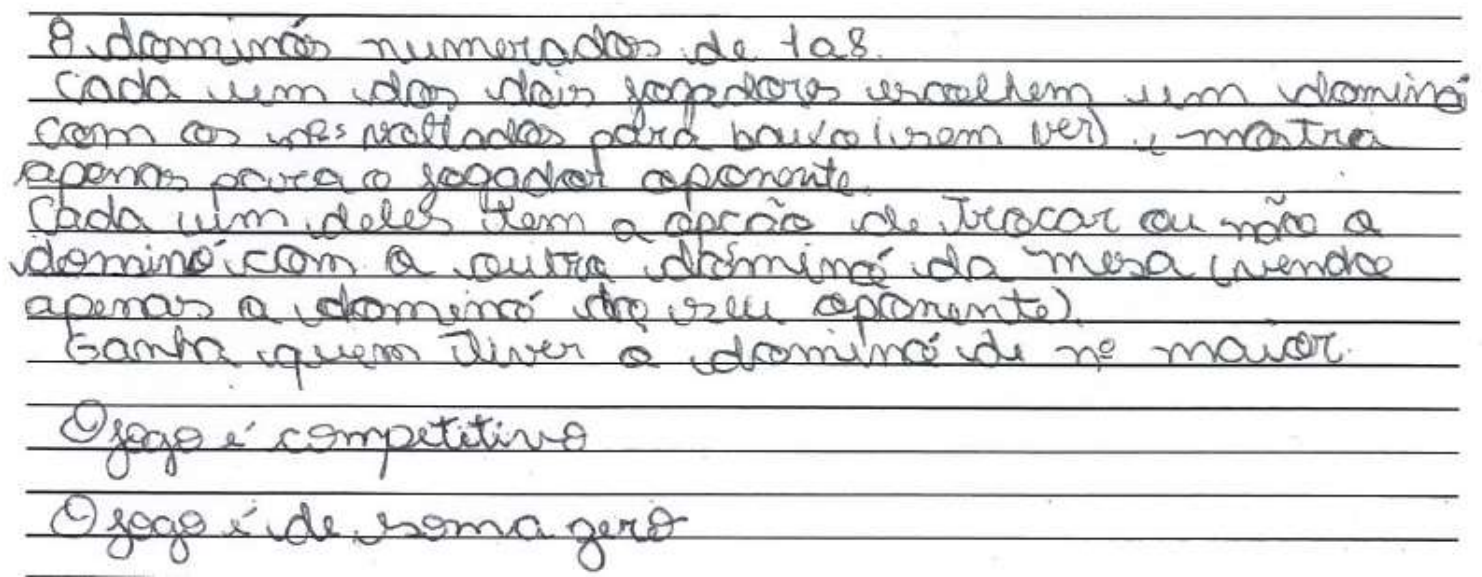

1. Criem uma situação de jogo de conflito com dois jogadores. Digam se o jogo é: Cooperativo ou Competitivo. Se for Competitivo, diga se é de Soma Zero ou de Soma Não Zero.

$$
\text { I. II ow II }
$$

is 2 participonter.

fom um precamo de tV, w apresentador do'3 upcöers

(or prêmion pexiam 500 mil vecies, 1 cass e 1 cavera.

Definer - ves cos vopcöes I - II - III.

I - Se ior does wxolherm diferentes, menhum gonho

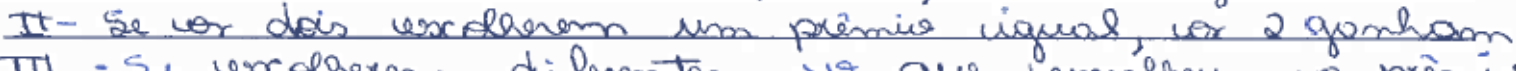

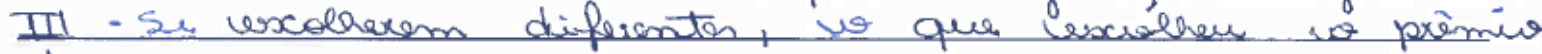
de menor valor comba.

- Ir 2 participantes màes podem re comumicar.

Joge competitive de soma nöes zers


1. Criem uma situação de jogo de conflito com dois jogadores. Digam se o jogo é: Cooperativo ou Competitivo. Se for Competitivo, diga se é de Soma Zero ou de Soma Não Zero.

"mais a ale un passáro na gavola, do que dais voanda!"

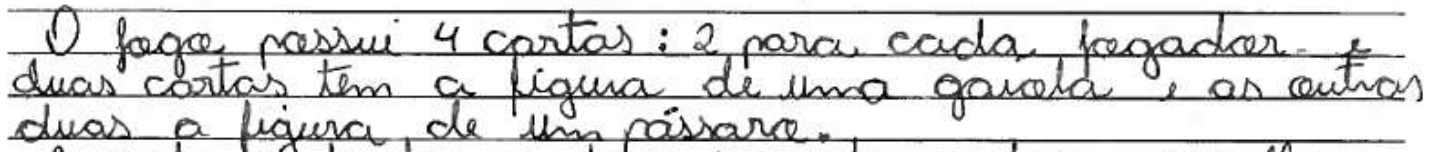
A cada fodada, empos pogadores dewn excolhen, Una das duas cartas para pogar (senda las suma

$\rightarrow S_{e}$ as foopdares. colrecoren dais pasáras guanham

$\rightarrow$ Se anbas logarem gaicla, perdem $\rightarrow$ Se un fogar spiola e o outro pásiare, a gaiola

fogo de soma nấo gero, competetiver.

1. Criem uma situação de jogo de conflito com dois jogadores. Digam se o jogo é: Cooperativo ou Competitivo. Se for Competitivo, diga se é de Soma Zero ou de Soma Não Zero.

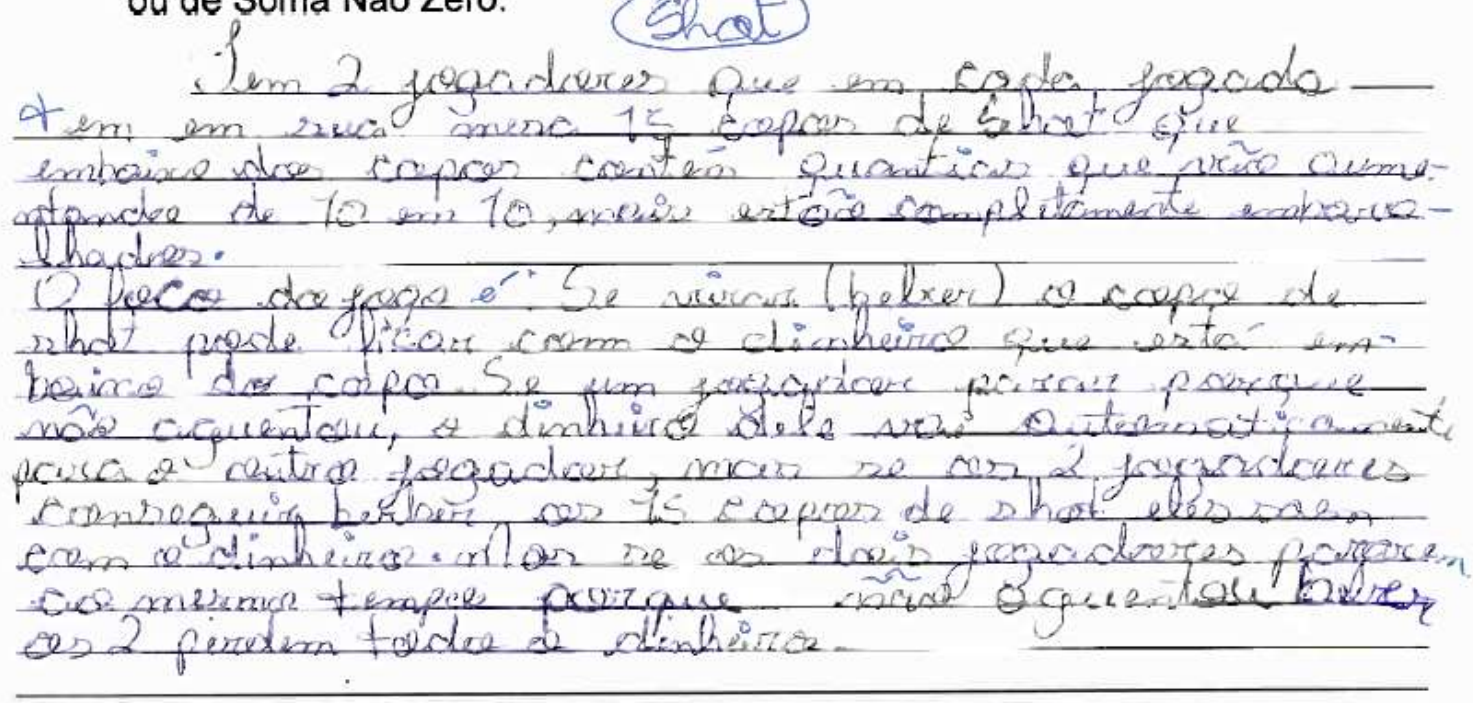

Eisse jogo é roma ñ gero/Cogprative

Na sexta aula que foi uma aula dupla, cada grupo analisou o jogo proposto por outro grupo, de modo à melhorá-lo, quando necessário, e procurar o melhor resultado se houvesse, de acordo com os pressupostos da Teoria dos Jogos.

O objetivo desta aula foi incentivar os alunos a analisarem uma situação de jogo de conflito, bem como a tomarem decisões ao lidar com a mesma.

Foram distribuídos as cópias dos jogos criados e uma folha contendo sete questões sobre a situação de jogo elaborada, de acordo com os conceitos básicos dessa teoria. 
Atividade 6 Leiam o texto (criado por outro grupo).

1 A situação de jogo proposta está bem definida?

2 As estratégias de cada jogador estão claras?

3 Caso necessário, reescreva de modo que realmente exista uma situação de jogo de conflito.

4 Trata-se de um jogo Cooperativo ou Competitivo?

5 Soma Zero ou Soma Não-Zero (responda somente se o jogo for Competitivo)?

6 Qual é a melhor estratégia para um dos jogadores?

7 Qual é a melhor solução para esse jogo?

A seguinte folha contendo a atividade realizada por um grupo, sem os nomes dos participantes, foi entregue a um outro grupo:

1. Criem uma situação de jogo de conflito com dois jogadores. Digam se o jogo é: Cooperativo ou Competitivo. Se for Competitivo, diga se é de Soma Zero ou de Soma Não Zero.

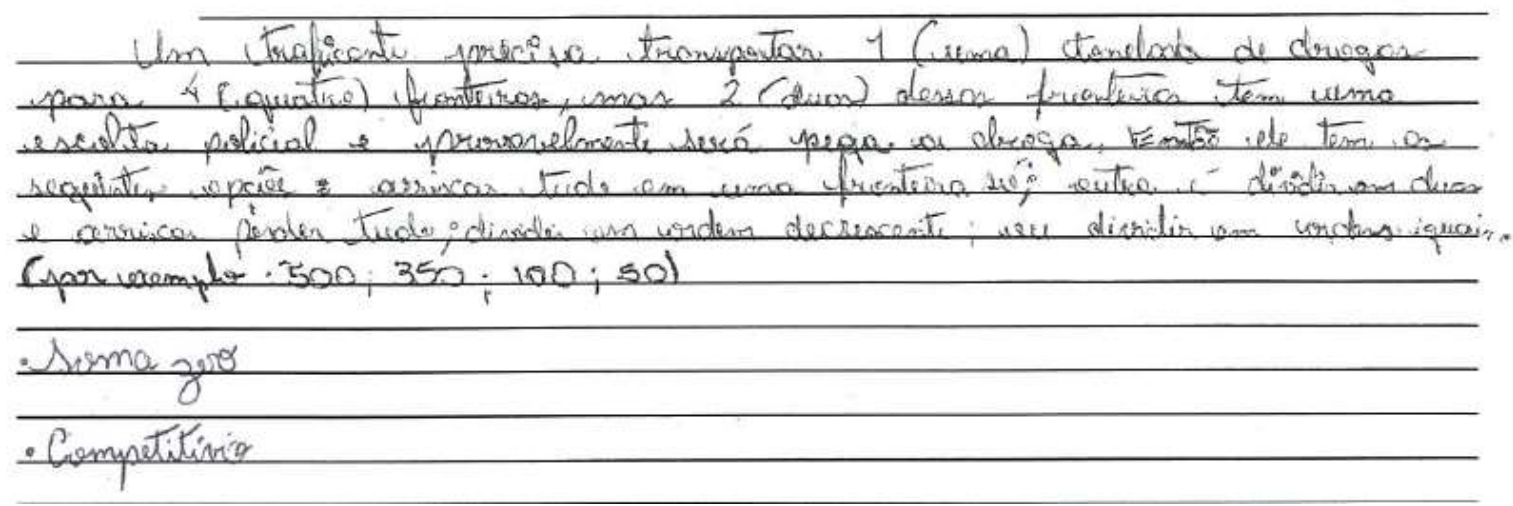

O grupo que recebeu a situação acima, fez a seguinte análise:

1- A situaçåo de jogo proposta está bem definida?

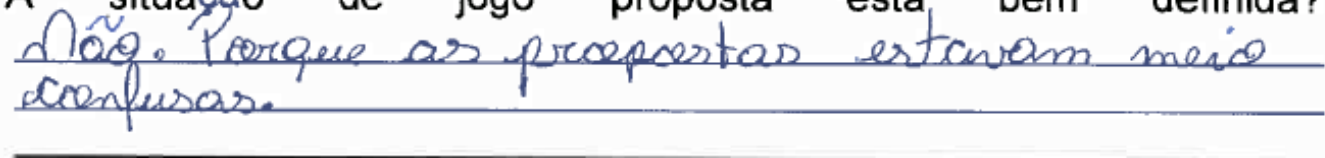

2- As estratégias de cada jogador estão claras? Vm pouro. Poís tem emas partes que 
3- Caso necessário, reescreva de modo que realmente exista uma situação

de

jogo

de

conflito.

Um or raficante precisa ofransprertar 1 (uma) tomelada de drregas para 4 (quatral fresteiras smas 2(duar) derras fronteiras tem uma

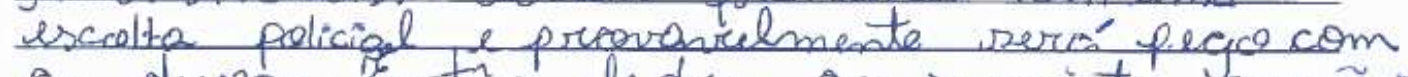
el droga. Entás ele tem as secuesintes vopcốs: - Aroúciar tudso en unea fronteiva ró; dinisidir em deras partes l arriscourg reu dividir tida?

4 Trata-se de um jogo Cooperativo ou Competitivo? bompetitioro

5- Soma Zero ou Soma Não-Zero (responda somente se o jogo for Competitivo)?

nomo nis - zow

6- Qual é a melhor estratégia para um dos jogadores?

A melcor estrategia édividir a droga em duos frontelras

7- Qual é a melhor, solução para esse jogo? A meler solucäo é parsar primeiro pelas duas fropteiras sem escolta, garantina ousin metade do gantre depor arriscar nas

A folha a seguir, também contendo a atividade de um dos grupos foi, da mesma forma, entregue a outro grupo: 
1. Criem uma situação de jogo de conflito com dois jogadores. Digam se o jogo é: Cooperativo ou Competitivo. Se for Competitivo, diga se é de Soma Zero ou de Soma Não Zero.

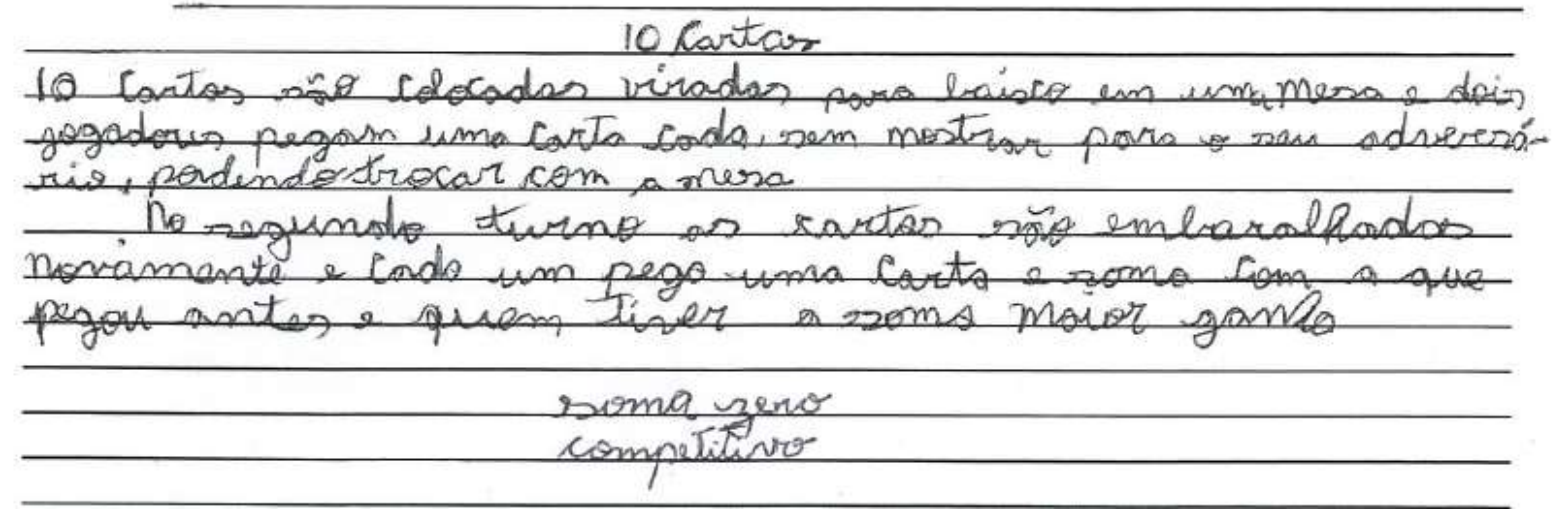

A seguinte análise foi feita pelo grupo que a recebeu: 1- A situação de jogo proposta está bem definida?

2- As estratégias de cada jogador estão claras? Lim, mos pudem ser melhorodos

3- Caso necessário, reescreva de modo que realmente exista uma situação de jogo de conflito.

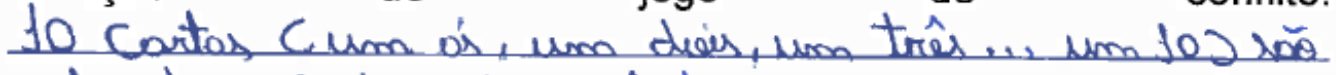
celvecudar vinodos pores lrowo ne mess.

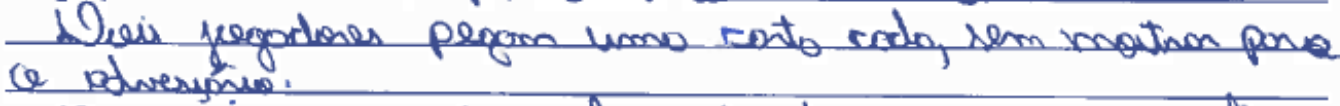

No primios rodado ale pode troen sue costa escolledo com umador catas que eition mo mero.

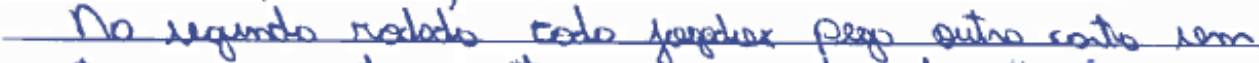

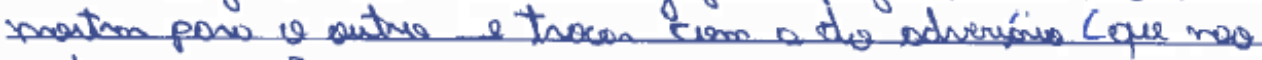
prote resuran.

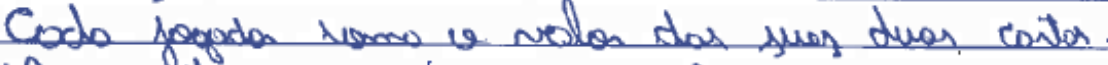

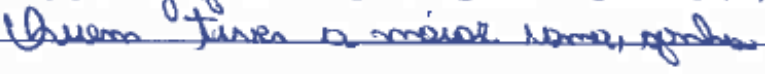

4- Trata-se de um jogo Cooperativo ou Competitivo? Competitures

5- Soma Zero ou Soma Não-Zero (responda somente se o jogo for Competitivo)?

Somo zous 
6- Qual é a melhor estratégia para um dos jogadores? Irover yuo costur e ela tiven volea brourso

7-. Qual é a melhor solução para esse jogo? miristos beluricos

A próxima folha, também preenchida com a atividade de um dos grupos, foi, da mesma forma, entregue a um outro:

1. Criem uma situação de jogo de conflito com dois jogadores. Digam se o jogo é: Cooperativo ou Competitivo. Se for Competitivo, diga se é de Soma Zero ou de Soma Não Zero.

$(\theta$ bestor)

em $\frac{2}{2}$ pessoas estarionn sem gavolino. Ho parapechar il tende visends 2 litrior

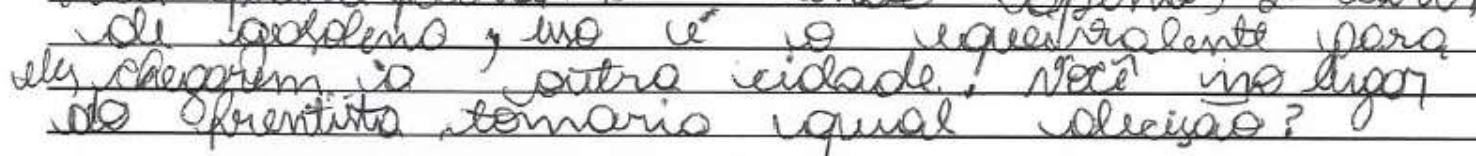

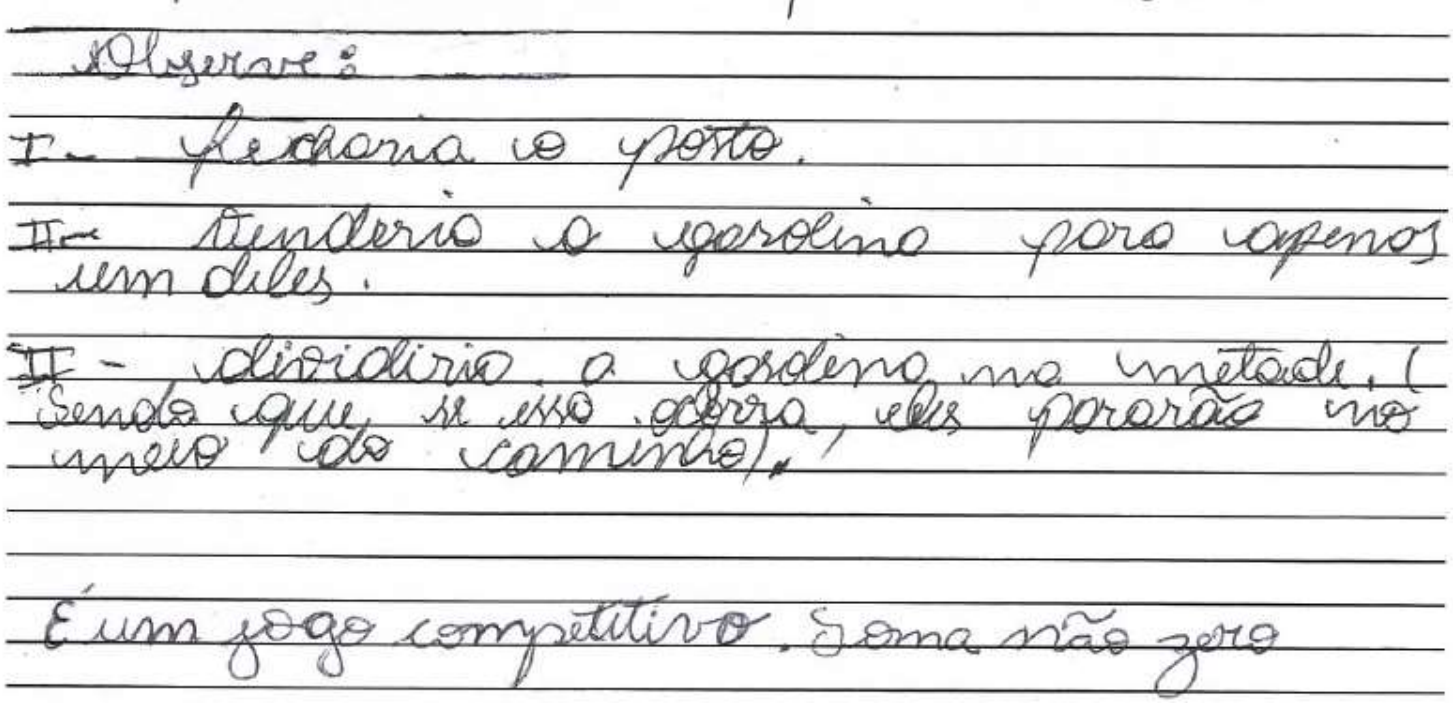

O grupo, por sua vez, fez a análise seguinte:

1- A situação de jogo proposta está bem definida?

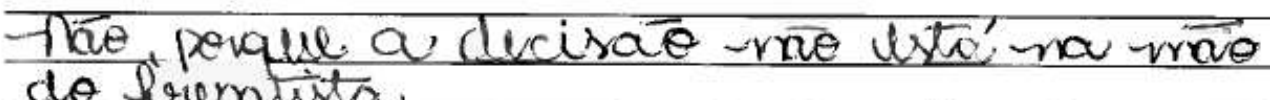
do fremusto

2- As estratégias de cada jogador estão
claras? Sim esta 
3- Caso necessário, reescreva de modo que realmente exista uma situação de jogo de conflito.

Zuas pexseas ettavam yem gaxolena um usus viculos. O posto de gavolena ustara para fechar e tendo aperras 2 litros de gasolina (vso véo. igurvalente paras chegar a outra cidade). Oque vici faria ise forse uma dessas persoas? 1-tentaria comprax a gasolina usó para us 2-Tentaria dividio a gasolina e parar no mio do caminho (combinando ventre uxi)

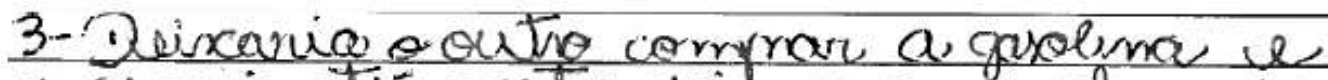
usponia ate oditho dia pana encher csece tanque

4- Trata-se de um jogo Cooperativo ou Competitivo? O) poge pode iser coopuativo quanto
competuluso

5- Soma Zero ou Soma Não-Zero (responda somente se o jogo for Competitivo)?

Sendo compututuri, Usoma nāo-zero.

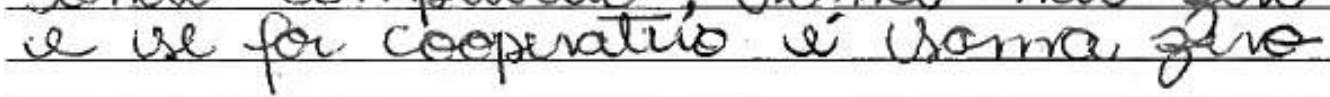

6- Qual é a melhor estratégia para um dos jogadores? Umuó comprar a gasolina e vai para outra cidade e depois o oritro trás a gasolina

7- Qual é a melhor solução para esse jogo? So um comprar à gaxolina.

A sétima e última aula foi reservada para aos alunos mencionarem suas impressões a respeito da Teoria dos Jogos e suas aplicações, através de abordagens feitas pela professorapesquisadora. O objetivo foi verificar a opinião dos alunos sobre essa teoria. 
Para esta discussão, as carteiras da sala de aula foram dispostas no formato de semicírculo. A professora-pesquisadora propôs três questões aos alunos para exposição de opiniões, oralmente, com o intuito de verificar o impacto das atividades realizadas, quanto ao tratamento de situações de jogos de conflito:

Primeiramente foi questionado o significado de "jogo" depois da realização das várias atividades.

Em seguida foi solicitado que os alunos explicassem, brevemente, o que é Teoria dos Jogos. E finalmente foi proposto que os alunos citassem onde os mesmos poderiam usar a Teoria dos Jogos.

Após as discussões a professora-pesquisadora fez o fechamento com uma exposição sobre a presença da Teoria dos Jogos na justiça e na política, com a projeção dos seguintes textos:

1 O juiz Gustavo Carvalho Chehab, da $3^{a}$ Vara do Trabalho de Brasília, utilizou a Teoria dos Jogos para provar provar que um ex-servidor dos Correios não foi responsável por um prejuízo que a empresa teve na contração emergencial de transporte aéreo. Chehab afirmou que grande parte dos julgamentos decide se uma atitude foi correta ou não, ou seja, examina a conduta de forma isolada, sem considerar opções possíveis e a intervenção de outras pessoas no processo decisório. Ele declarou então que a Teoria dos Jogos tem a capacidade, prever o resultado de tais ações e o comportamento das partes, de forma lógica e objetiva. O juíz apresentou uma tabela de ações contendo os diversos cenários possíveis envolvendo os contratos, bem como seus resultados, para mostrar que o servidor tomou a atitude "estrategicamente" mais correta. Dessa forma, o juiz determinou que o ex-servidor dos Correios, demitido por justa causa após processo administrativo, fosse reintegrado ao emprego (adaptado de Consultor Jurídico, 16 jun. 2017).

2 No Brasil, a delação premiada foi regulada pela lei 12.850, que entrou em vigor em 2013. Os criminosos sabem que há regras claras que podem beneficiá-los ou, se forem alvo de delação, prejudicá-los. A tendência é os comparsas permanecerem em silêncio, dada a dificuldade para o poder público descobrir detalhes de crimes mais complexos. Por isso, a estratégia consiste em oferecer incentivos à delatores, da seguinte forma: o primeiro criminoso que colaborar, se não for o líder da organização criminosa, pode ter pena zero e nem ser denunciado pelo Ministério Público; quem ficar por último terá menos a contar ou 
precisará delatar mais para obter os mesmos benefícios que os pioneiros (adaptado de Nexo, 25 mai. 2016).

Após, a professora-pesquisadora expôs também o fato de que a "delação premiada", que entrega ao poder público um volume de informações sobre crimes que ele seria incapaz de apurar, pode ser também abordada utilizando-se a Teoria dos Jogos. 


\section{CAPÍTULO 5}

\section{ANÁLISE DO EXPERIMENTO DE PESQUISA}

"Em uma estratégia, é importante ver o que está distante como se estivesse próximo e ter uma visão distanciada do que está próximo. "(Miyamoto Musashi)

O presente capítulo contém a análise das três etapas do experimento de pesquisa, no que tange aos objetivos apontados, bem como à metodologia utilizada.

\subsection{CONCLUSÕES SOBRE O EXPERIMENTO}

Na primeira aula do experimento realizado, os objetivos propostos foram atingidos. A atenção dos alunos para situações de jogos de conflito foi despertada e os mesmos trabalharam o desenvolvimento de estratégias sobre os dois primeiros jogos propostos: Dilema do Prisioneiro e Sete e Meio.

$\mathrm{Na}$ atividade com o Dilema do Prisioneiro, os alunos perceberam as consequências das possibilidades na situação proposta: os grupos confrontaram as opções disponíveis para cada uma das partes envolvidas, buscando uma escolha. Dos nove grupos participantes, sete escolheu a estratégia dominante para os prisioneiros, o que demonstra que a maioria deles foram capazes de lidar com uma situação básica da Teoria dos Jogos.

Com relação ao jogo Sete e Meio, a grande maioria dos integrantes dos grupos não apontou uma estratégia dominante, mas discutiu estratégias sob o ponto de vista da cooperação, ou seja, dividir o prêmio.

O objetivo da segunda aula foi plenamente atingido, pois os alunos foram estimulados a expor suas conclusões sobre as situações de jogo apresentadas, de forma que um integrante de cada grupo proferiu as constatações dos mesmos. Além disso, alguns integrantes de cada grupo puderam exercitar a argumentação e atitude de convencimento, quando grupos de mesma opinião tentaram convencer outros grupos.

Em relação à terceira aula do experimento, quando foi apresentado um trecho do filme Uma Mente Brilhante (Howard, 2001), o objetivo foi atingido, pois a atitude de cooperar foi 
discutida como estratégia. A grande maioria dos grupos chegou à conclusão de que o melhor resultado é quando todos fazem o melhor para si e para todos. Um dos grupos admitiu que o caráter e a fidelidade são importantes para o indivíduo numa situação de jogo de conflito. Boa parte dos grupos também identificou um ponto particular dos jogos cooperativos na situação da cena projetada: a possibilidade de ganho para ambos os envolvidos. Torna-se válido mencionar que a professora-pesquisadora pode perceber a identificação, por parte de muitos alunos, de que tal cena consistia numa situação de jogo; além disso, quase todos os alunos compreenderam e concordaram com a estratégia do personagem.

Sobre a quarta aula, os alunos puderam conhecer os pressupostos da Teoria dos Jogos, por meio da exposição da professora-pesquisadora, após o trabalho com os jogos apresentados. Cabe acrescentar que alguns alunos opinaram sobre o fato dessa teoria ser útil para trabalhar situações que envolvem comunicação, percepção e raciocínio lógico, ou simplesmente, ser útil apenas para jogos.

O objetivo da quinta aula foi parcialmente atingido, uma vez alguns grupos elaboraram jogos que não eram efetivamente de conflito, assim como outros elaboraram jogos semelhantes aos jogos trabalhados nas atividades. No entanto, nesse ponto, os mesmos demonstraram entender o que venha ser uma situação de jogo.

Também foi atingido parcialmente o objetivo da sexta aula, visto que quase todos os grupos ao reelaborarem o jogo criado pelos outros, melhoraram o conflito, porém, mantiveram o padrão, ou seja, a semelhança com os jogos que foram expostos nas atividades anteriores. Torna-se relevante mencionar que todos os grupos encontraram a solução do jogo.

Em relação à sétima e última aula (fechamento), torna-se útil para análise uma tabulação dos comentários sobre concepção de jogo, bem como sobre a concepção da Teoria dos Jogos que os alunos detêm após a realização das atividades.

\section{Sobre a ideia de jogo:}

\begin{tabular}{|c|c|}
\hline COMENTÁRIOS & No DE ALUNOS $^{\circ}$ \\
\hline Jogos de conflito são iguais a qualquer jogo & 7 \\
\hline Há estratégias em um jogo & 4 \\
\hline Existe a questão da moralidade em tomadas de decisão & 7 \\
\hline Uma busca por opções estratégicas & 4 \\
\hline Uma relação entre escolha e consequência & 5 \\
\hline As estratégias das situações de jogos relacionam-se com situações \\
da vida & 3 \\
\hline Um exercício da lógica e da argumentação & \\
\hline
\end{tabular}


2. Sobre o que é Teoria dos Jogos:

\begin{tabular}{|c|c|}
\hline COMENTÁRIOS & No DE ALUNOS $^{\text {É um estudo de jogos }}$ \\
\hline É a matemática que estuda estratégias de jogo & 10 \\
\hline $\begin{array}{c}\text { É o estudo de jogos cooperativos e competitivos, de soma zero e } \\
\text { não zero }\end{array}$ & 5 \\
\hline $\begin{array}{c}\text { É um ramo da matemática que observa melhores escolhas em } \\
\text { situações de conflito }\end{array}$ & 11 \\
\hline
\end{tabular}

3. Sobre aplicações da Teoria dos Jogos

\begin{tabular}{|c|c|}
\hline COMENTÁRIOS & No DE ALUNOS $^{\circ}$ \\
\hline Em qualquer tipo de jogo & 7 \\
\hline Em muitas situações com dois ou mais participantes & 14 \\
\hline Em situações onde há um objetivo comum entre os envolvidos & 9 \\
\hline Em qualquer situação envolvendo um desafio para obter um ganho & 8 \\
\hline
\end{tabular}

Através dessa tabulação, pode-se concluir que vários alunos compreenderam conceitos da Teoria dos Jogos; uma boa parcela de alunos conceberam a ideia de se buscar opções em uma situação de jogo, reconhecendo as consequências de cada opção. No entanto, alguns alunos não conseguiram identificar o diferencial que um jogo de conflito têm em relação a um simples jogo. Em contrapartida, alguns compreenderam os pressupostos dessa teoria, bem como outros levaram os ideais das situações de jogos para a vida.

O experimento mostrou que esse grupo de alunos é capaz de entender a ideia de uma situação-dilema e tomar decisão sobre a mesma. Independentemente de conseguir ou não identificar a melhor decisão, a maioria dos alunos demonstrou ser capaz de agir mediante uma situação de jogo de conflito, bem como compreendê-la e argumentar sobre ela. Isso demonstra o aspecto prospectivo da pesquisa Design Experiment, ou seja, o experimento partiu da conjectura sobre o tratamento, por parte dos alunos, de situações de jogos de conflito.

Os alunos, em sua maioria, demonstraram dificuldade em criar situações inéditas de jogo, próprias dessa teoria. Porém, demonstraram também serem capazes de assimilar uma situação proposta e de pensar nas possibilidades de solução da mesma. Dentro desse contexto encontra-se a intensão da metodologia de pesquisa em compreender como se dá a aprendizagem.

As atividades propostas nesse experimento deixaram claro que, ao lidar com uma situação pertinente à Teoria dos Jogos, a maioria dos alunos busca tomar decisões, mesmo sem, muitas vezes, conseguir optar pela melhor estratégia. 
Mediante as atividades do experimento, grande parte dos alunos desenvolveu a busca por estratégias em situações de jogos, percebendo que a ação de um gera consequências na ação do outro jogador. O envolvimento dos mesmos com as atividades merecem destaque, visto que os jogos dessa teoria despertaram neles um estímulo pela compreensão.

A professora-pesquisadora, de modo geral, surpreendeu-se com a capacidade de entendimento, por parte dos alunos, dos dilemas propostos, bem como pela curiosidade desses em buscar possibilidades de resolução, mesmo alguns demonstrando dificuldade.

Os alunos também levantaram as seguintes questões novas através do trabalho com as atividades: até que ponto existe ética para um jogador? Nas situações de jogo da sociedade deve-se exercer a cidadania? Cabe mencionar aqui o aspecto reflexivo da metodologia Design Experiment, ou seja, a possibilidade de surgimento de novas conjecturas, bem como o aspecto cíclico: aplicar, repensar e até reelaborar um experimento.

\subsection{PROPOSTA DE REDESIGN DO EXPERIMENTO}

Com vistas a buscar atingir o objetivo da primeira aula, a questão 2 da Atividade 2 pode ser assim (re)formulada: "Na opinião de vocês, o que os jogadores devem combinar e o que devem cumprir para obter o melhor ganho? Por que?" Isso pode conduzir os alunos à compreensão de que um jogador busca induzir o outro ao seu benefício e que, portanto, ambos podem combinar escolher "meio", mas pode mudar de ideia para tentar ganhar o jogo. Ou seja, pode facilitar o pensamento de que se um jogador busca o maior ganho (maior prêmio nesse caso), então isso não implica em dividir o prêmio. Pode-se também propor atividades utilizando o aplicativo ncase.me/trust/, que simula jogos de dois jogadores e que possibilita discutir que estratégias ótimas num jogo depende essencialmente da estratégia do jogador oponente.

Para atingir os objetivos da quinta e da sexta aula, a proposta de criação de uma situação de jogo, bem como da reelaboração, poderia ser feita após a apresentação de outros tipos jogos dessa teoria, a fim de diversificar as possibilidades de criação e evitar uma elaboração tão análoga a um dos jogos já instituídos (cópias modificadas). Por exemplo, poderiam ser incluídos:

Barganha com ultimato: A banca concede um prêmio a uma pessoa, o líder, que deverá dividi-lo com uma segunda pessoa, o receptor, oferecendo-lhe uma oferta. Porém se o receptor recusar essa oferta, a banca não pagará nada a nenhum dos dois;

Batalha dos Sexos: um casal está decidindo qual programa irá fazer. O rapaz prefere 
ir ao futebol do que ir ao show de música, que acontecem ao mesmo tempo; a garota prefere ir ao show de música. O problema é que eles ficaram sem poder se comunicar e têm de tentar se encontrar em um desses dois eventos;

Jogo do Covarde: dois adolescentes pilotam carros em um teste de coragem; aquele que desviar o carro primeiro será chamado de covarde.

Tais jogos estão descritos e analisados no Capítulo 1.

Outra possibilidade para a produção de situações de jogos de conflito mais diversificadas e inéditas, por parte dos alunos, seria oferecer aos mesmos mais tempo para a criação, não apenas uma aula, mas sim alguns dias, para que os grupos pudessem pensar e pensar mais sobre situações de conflito, uma vez que a metodologia Design Experiment permite flexibilização no período das atividades.

Em consonância com as particularidades da metodologia Design Experiment, uma nova conjectura foi promovida durante a aplicação do experimento: abordar situações de jogos de conflito podem trazer à tona temas como ética e moral. Isso porque a ocorrência do levantamento desses temas no decorrer das atividades, por parte dos alunos, de fato, ocorreu. Ou seja, as situações de jogos em si além de poder ser visto como um novo tema transversal, como já pensado inicialmente, também abrange outros temas, tipicamente transversais.

Esses temas pertinentes ao campo da filosofia, permitem, inclusive, uma abordagem interdisciplinar. Tem-se então uma outra conjectura percebida: a Teoria dos Jogos como atividade interdisciplinar entre a matemática e a filosofia.

Mesmo que na Teoria dos Jogos não se procura analisar as situações de conflito do ponto de vista de ações "erradas" ou "certas", pode-se incluir questionamentos sobre responsabilidade, justiça e valores. Pode-se então propor um redesign da pesquisa, sugerindo uma discussão ética nas situações de jogos na aula de filosofia, bem como acrescentando a cada uma das atividades pensadas, questões pertinentes a um contexto ético.

As atividades envolvendo os jogos: Dilema do Prisioneiro e Sete e Meio, podem instigar os alunos a pensarem sobre a melhor estratégia de cada situação apresentada e o "correto" a se fazer, em termos de convivência.

Em relação à atividade envolvendo o jogo Le Her, pode-se questionar, enquanto atitude de caráter, o blefe, sobretudo em situações de jogos de conflito presentes na vida.

No que diz respeito à atividade sobre a cena do filme "Uma Mente Brilhante", pode-se propor aos alunos avaliar a ideia do personagem, em termos de consideração ética ao se deparar com esse tipo de situação (de jogo de conflito) na vida. 


\section{CONSIDERAÇÕES FINAIS}

Como fechamento desse trabalho, cabe fixar que, por se tratar de uma vertente matemática que estuda decisões ótimas para situações de conflito, a Teoria dos Jogos se faz presente em diferentes áreas do conhecimento, englobando aspectos pertinentes ao cotidiano das relações entre os indivíduos; dessa maneira, a educação não pode ficar de fora do campo de aplicações dessa teoria.

Revisando as bases dessa pesquisa, vale dizer que formar educandos também consiste em prepará-los para lidar com situações de conflitos, usando de estratégia e, neste aspecto, tem-se a noção de tal teoria, que sempre fez parte da humanidade.

Ainda repassando o embasamento dessa investigação, pode-se constatar que denominar por racional a opção que garante ao indivíduo maior vantagem dentro de uma situação, diante daquilo que outros fazem, bem como demonstrar isso por meio de esquemas de comparação, são atividades próprias dessa teoria que devem ser então trabalhadas na educação básica.

Antes de começar a concluir esse trabalho, deve-se destacar que, como precursor no estudo dessa teoria, Von Newman deixou indiretamente sua aplicabilidade para a vida em sociedade, ao constatar que em todo jogo entre dois agentes, há um resultado ótimo para ambos. Jonh Nash, por sua vez, provou ser esse resultado o equilíbrio em um jogo, ou melhor, em uma situação da vida em sociedade.

Além disso, para partir às conclusões, pode-se refletir novamente sobre o fato de que as situações de jogos de conflito são identificadas quando um agente toma decisões que interferem nas decisões tomadas por outros agentes e, sendo assim, as mesmas devem ser abordadas na escola, a fim de trabalhar a busca por estratégias e a argumentação.

Ao mergulhar na Teoria dos Jogos, a pesquisadora percebeu um campo de trabalho para a sala de aula, que é um local de vivências, visto que situações-dilema tanto podem se apresentar pela vida em momentos de cooperação como em momentos de competição, onde se é possível identificar nos mais variados contextos, jogos de Soma Zero ou Soma Não Zero.

Todo esse estudo realizado observa as situações de jogos como sendo condizentes com a atividade escolar, por exigirem a busca por uma melhor estratégia, ou seja, uma estratégia dominante, que trás a um agente um melhor benefício em relação às estratégias dos outros envolvidos: algo útil na vida em sociedade.

A noção de Equilíbrio de Nash, por enfocar o par de estratégias de ambos os 
envolvidos, onde, independentemente da escolha do outro, trás para cada um o melhor resultado, favorece o enfoque da relação entre o cooperar e o competir, importante na formação de futuros cidadãos.

Finalmente, a pesquisadora lembra ao leitor que a aplicação de tal teoria em sala de aula condiz com a exigência das diretrizes da educação básica, em formar alunos capazes de dominar estratégias para atuar em situações, apresentando autonomia em suas escolhas. Até mesmo as avaliações externas requerem dos alunos habilidades de ação em situações de diversos contextos; essas habilidades de agir e decidir são trabalhadas mediante situações em forma de jogo.

Mesmo lançando mão apenas dos conceitos básicos da Teoria dos Jogos, a pesquisadora constatou ser adequado o uso dessa teoria na educação e que a mesma ainda pode ser muito investigada, no que tange à obtenção de benefícios.

Durante o experimento de pesquisa surgiu a percepção de que a Teoria dos Jogos em sala de aula pode contribuir para o trabalho de questões voltadas para ética, o que pode possibilitar até mesmo uma conexão interdisciplinar com a Filosofia.

Os objetivos dessa pesquisa foram, em geral, alcançados: houve a percepção por parte dos alunos de que existe uma teoria que trabalha situações-dilema; alguns dos elementos dessa teoria foram levados aos alunos, fazendo-os conhecer como a matemática lida com essas situações-dilema; também ocorreu a sensibilização dos alunos para situações de jogos de conflito e para lidar com as mesmas.

A conclusão de que o experimento realizado sensibilizou os alunos para a existência de situações de jogos de conflito, justifica-se uma vez que os mesmos se mostraram demasiadamente interessados nas situações-dilema, reagindo de modo a tentar encontrar a melhor saída para as mesmas, discutindo entre eles.

Em decorrência disso, cabe concluir também que o experimento apresentado foi um espaço onde os alunos puderam questionar a cooperação enquanto estratégia, frente à situações de conflito, bem como participaram efetivamente das atividades.

No entanto, não foi possível explorar, durante o experimento realizado com os alunos, mais exemplos clássicos da Teoria dos Jogos. Isso se justifica pelo fato de alguns dos outros exemplos exigirem habilidades não recomendadas ao nível de ensino ao qual os alunos fazem parte, bem como por questões de tempo de realização da pesquisa.

O fato de abordar poucos exemplos clássicos fez com que no momento da criação de situações-dilema, os alunos ficassem pautados apenas nesses exemplos.

A proposta de avaliar as situações de jogos de conflito criadas pelos colegas, 
favoreceu na maioria dos alunos a busca de estratégias para a resolução das situações e a tomada de decisão sobre as mesmas. Porém, alguns alunos demonstraram estarem presos aos poucos exemplos trabalhados, até mesmo durante o processo de avaliação das situações criadas.

A pesquisadora reconhece que se pudesse repetir o experimento, procuraria organizar um trabalho com os demais jogos clássicos da teoria, mesmo não propondo sistematizações sobre alguns desses jogos, em consonância com o nível escolar dos alunos; também traria discussões éticas sobre os dilemas.

Contudo, a experiência de trabalho realizada, apesar de simples, tornou-se capaz de produzir o interesse efetivo por parte dos alunos e, portanto, recomendada pela pesquisadora a um professor que aprecie explorar novas vertentes da matemática em sala de aula.

A conclusão da pesquisadora sobre esse trabalho é: a aplicação da Teoria dos Jogos para o professor de matemática na escola é um trabalho interessante e fértil. A mudança que essa investigação trouxe para a prática da professora-pesquisadora foi o reconhecimento dos benefícios de explorar novas vertentes da Matemática em sala de aula, uma vez que essa atitude gera motivação e empenho para os envolvidos.

Ao presenciar os alunos empenhados em resolver os dilemas propostos, como em geral não estariam se as atividades propostas contemplassem uma vertente matemática mais habitual, a professora-pesquisadora mudou sua forma de considerar as situações de aprendizagem diferenciadas no cotidiano escolar.

Ao leitor, cabe dizer que a ideia do experimento realizado nessa pesquisa, em abordar, sistematizar e propor a criação de situações de jogo de conflito, mobilizou os educandos a despertar a busca pela habilidade de tomar decisão.

Se em todo jogo há um resultado ótimo para cada jogador, toda pessoa pode buscar estrategicamente sua melhor solução em cada situação da vida. 


\section{REFERÊNCIAS}

A BEAUTIFUL Mind. Direção: Hon Howard, Produção: Brian Grazer. Estados Unidos: Universal Pictures, 2001, 1 DVD (135 min.), son., color.

BIEMBENGUT, M. S.; HEIN, N. Modelagem matemática no ensino. 3.ed. São Paulo: Contexto, 2003.

BILLI, M. Teoria dos jogos rende Nobel de Economia. Folha de São Paulo, São Paulo, 11 out. 2005. Disponível em: 〈http://www1.folha.uol.com.br/fsp/dinheiro/fi1110200533.htm>. Acesso em: 08 ago. 2017.

BORTOLOSSI, J.H.; GARBUGIO, G.; SARTINI, B. A. Uma introdução à Teoria dos Jogos. Rio de Janeiro: UFRJ, 2017. Disponível em: <http://www.professores.imuff.mat.br/hjbortol/arquivo/2017.1/tdj/bgs-teoria-dos-jogos.pdf >. Acesso em: 02 jan. 2018.

BRASIL. Ministério da Educação. Secretaria de Educação Fundamental. Parâmetros Curriculares Nacionais (PCN): Introdução dos Parâmetros. Brasília: MEC, 1998.

BRASIL. Ministério da Educação. Secretaria de Educação Média e Tecnológica. Parâmetros Curriculares Nacionais (PCN). Brasília: MEC, 1997.

Ministério da Educação. Secretaria de Educação Média e Tecnológica. Parâmetros Curriculares Nacionais: apresentação dos Temas Transversais. Brasília: DP\&A. MEC, 2000.

. Ministério da Educação. Secretaria da Educação Média e Tecnológica. Parâmetros Curriculares Nacionais + $(\mathrm{PCN}+)$ - Ciências da Natureza e suas Tecnologias. Brasília: MEC, 2002.

Ministério da Educação. Secretaria de Educação Média e Tecnológica Orientações

Curriculares para o Ensino Médio, v. 2, Conhecimentos de Matemática, Brasília: MEC/SEB, 2006

BRAVO, J. S. A política internacional e a crise dos mísseis. Revista Novas Fronteiras, Porto Alegre, RS, v. 2, n. 1, (jan - jun). 2015. Disponível em:

<novasfronteiras.espm.br/index.php/RNF/article/download/56>. Acesso em: 30 de abr. 2017

CARLETTI, A. Código de Hamurabi. In: CARLETI, A. Brocardos Jurídicos, São Paulo: Universitária de Direito, 1986, p. 161, p. 169-170.

$\mathrm{COBB}, \mathrm{P}$. Et al. Design experiments in education research. Educational Researcher, Washington, v.32, n.1, p.9-13, Ago. 2003.

COLLINS, Allan Et al. Design Research: Theoretical and Methodological Issues. Journal of the Learning Sciences, Evanston, p.13-42, Jan. 2004.

FELICIANO, L. P. Teoria dos Jogos: uma nova proposta para o ensino médio. 2007. 163f. Dissertação (Mestrado Profissional em Matemático) - Pontifícia Universidade Católica 
- PUC, São Paulo, 2007.

FIANI, R. Teoria dos Jogos: para cursos de administração e economia. São Paulo: Elsevier Editora LTDA, 2004.

Teoria dos Jogos: com aplicação em economia, administração e ciências sociais. São Paulo: Campus, 2006.

Teoria dos Jogos. 3. ed. São Paulo: Campus, 2009.

GALLI, M. Juiz usa teoria dos jogos para restabelecer vínculo de servidor dos Correios.

Consultor Jurídico, Belo Horizonte, MG, 16 jun. 2017. Disponível em:

$<$ https://www.conjur.com.br/2017-jun.../juiz-usa-teoria-jogos-restabelecer-vinculo-servidor-

correios.html>. Acesso em: 13 nov. 2017.

GUTH, W.; Schmitberger, R.; Schwarze, B. “An Experimental Analyis of Ultimatum

Bargaining", in Journal of Economic Behavior and Organization, 1982.

KARRER, M. Articulação entre Álgebra Linear e Geometia: um estudo sobre as transformações lineares na perspectiva dos registros de representação semiótica. 2006. 412f. Tese (Doutorado em Educação Matemática)-Pontífica Universidade Católica de São Paulo, São Paulo, 2006.

KASPER, Frederico A. Teoria dos Jogos: uma proposta para o ensino médio. PUC-SP, 2016. v. 3, n. 2. Disponível em: 〈https://revistas.pucsp.br/index.php/emd/article/view/31640>

Acesso em: 17 jan. 2017.

LUPION, B. Como a Teoria dos Jogos explica o comportamento dos delatores da Lava Jato. Jornal Nexo, São Paulo, SP, 25 Mai. 2016, Disponível em:

$<$ https://www.nexojornal.com.br/.../Como-a-Teoria-dos-Jogos-explica-o-comportamento-dosdelatores-da-lava-jato.html.> Acesso em: 12 nov. 2017.

MAYNARD, S. Evolution and the Theory of Games. Reino Unido: Cambridge Universiry Press, 1982.

MARTINS, Elen G. O papel da percepção sonora na atribuição de significados matemáticos para números racionais por pessoas cegas e pessoas com baixa visão. 2010 . 108f. Dissertação (Mestrado em Educação Matemática) - Universidade Bandeirantes UNIBAN, São Paulo, 2010.

NASAR, S. Uma Mente Brilhante. Trad: Sérgio Moraes Rego. Rio de Janeiro: Record, 1998.

NOBREGA, C. Antropomarketing: dos Flinststones à era digital. São Paulo: Senac, 2003.

Tudo está em jogo. Revista Superinteressante, São Paulo, SP, v. 1, n. 174, mar. 2002. Disponível em: <https://super.abril.com.br/ciencia/tudo-esta-em-jogo/>. Acesso em: 13 jun 2017.

PEREIRA, S. B. Intodudução à Teoria dos Jogos e a Matemática no ensino médio. 2014. 
68f. Dissertação (Mestrado em Educação Matemática) - Pontífica Universidade Católica PUC, Rio de Janeiro, 2014.

PFUTZENREUTER, E. Silvio Santos e a Teoria dos Jogos. GMT, 2002. Disponível em: <https://epxx.co/artigos/silviosantos2.html>. Acesso em: 30 Abr 2017.

PIMENTEL, E. L. A. Dilema do Prisioneiro: Da teoria dos jogos à ética. Belo Horizonte: Argumentum, 2007.

SANTOS, J. P. A Teoria da Probabilidade e a Teoria dos Jogos em uma abordagem para o ensino médio. 2016. 72f. Dissertação (Mestrado Profissional em Matemática)Universidade Federal do Rio Grande do Norte - UFRN, Rio Grande do Norte, 2016.

TUROCY, T. STENGEL, B. Game Theory. Londres: CDAM Research Report, 2001. Disponíverl em: <www.maths.lse.ac.uk/personal/stengel/bvs-publ.html $>$. Acesso em: 11 maio. 2015

TZU, Sun. A arte da guerra: os treze capítulos originais. 13 ed. São Paulo: Martins Fontes, 2014 
ANEXOS 


\section{TERMO DE CONSENTIMENTO LIVRE E ESCLARECIDO}

Eu compreendo os direitos dos participantes da pesquisa intitulada"SITUAÇÕES DE CONFLITO: UMA APLICAÇÃO DA TEORIA DOS JOGOS EM SALA DE AULA",orientada por Dra. Cristina Cerri, e que tem como pesquisadora responsável: Roseli Rocha Teixeira, estudante do Instituto de Matemática e Estatística da Universidade de São Paulo, os quais podemser contatados/as pelo e-mail zelika@ime.usp.br ou cerri@ime.usp.br ou telefone (11)4184-5707 ou (11)30916152. Na qualidade de responsável pela E E Prof. Manoel da Conceição Santos, autorizo a participação de estudantesna mencionada pesquisa e compreendo como e porque esse estudo está sendo realizado. Os responsáveis pela pesquisa garantem o sigilo, assegurando a privacidade dos sujeitos quanto aos dados envolvidos na pesquisa. Receberei uma cópia assinada deste formulário de consentimento.

Assinatura do responsável.

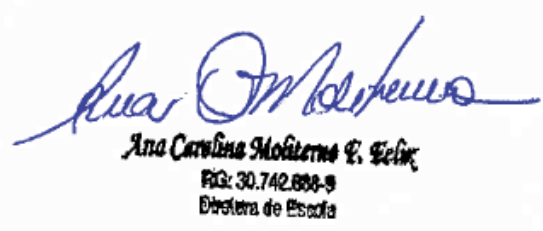




\section{TERMO DE CONSENTIMENTO LIVRE E ESCLARECIDO}

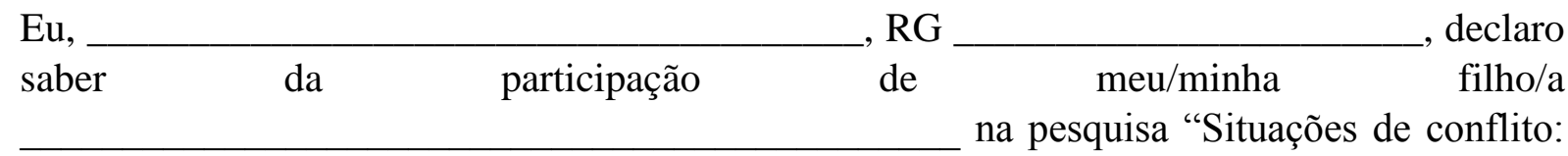
uma aplicação da Teoria dos Jogos em Sala de", desenvolvida junto ao Instituto de Matemática e Estatística da Universidade de São Paulo pela pesquisadora professora Roseli Rocha Teixeira, orientada pela professora Dra. Cristina Cerri, as quais podem ser contatadas pelo e-mail zelika@ime.usp.br ou cerri@ime.usp.br ou telefone (11)4184-5707 ou (11)30916152. O presente trabalho tem por objetivos: utilizar os pressupostos básicos da Teoria dos Jogos na formação escolar, com vistas a investigar sua aplicabilidade para promover um espaço que aborde a capacidade de tomada de decisão, como sendo uma importante habilidade na vida do indivíduo, e os instrumentos utilizados são: atividades práticas individuais e/ou em grupos realizadas em sala de aula da escola E.E. Manoel da Conceição Santos. Compreendo que tenho liberdade de retirar o meu consentimento em qualquer fase da pesquisa, sem penalização alguma. A qualquer momento, posso buscar maiores esclarecimentos, inclusive relativos à metodologia do trabalho. As responsáveis pela pesquisa garantem o sigilo, assegurando a privacidade dos sujeitos quanto aos dados envolvidos na pesquisa. Declaro compreender que as informações obtidas só podem ser usadas para fins científicos, de acordo com a ética na pesquisa, e que essa participação não inclui nenhum tipo de pagamento.

Carapicuíba,

Nome do responsável

Assinatura do responsável 
Alunos:

Atividade 1

Leiam o texto a seguir e respondam as questões:

Dois homens cometeram um crime juntos e foram capturados. Eles estão presos em celas separadas e sem comunicação entre eles. Ambos serão interrogados separadamente e receberão a seguinte proposta: se os dois negarem o crime, serão condenados a 1 ano de prisão; se os dois confessarem, serão condenados a 5 anos; se um confessar e o outro negar, o que confessou será libertado e o outro será condenado a 10 anos de prisão. No entanto, um não poderá saber a resposta que o outro dará.

1 Na opinião de vocês, cada prisioneiro ao ser chamado deve confessar ou não? Por quê?

2 Após a discussão da questão 1, descrevam todas as possibilidades que pode acontecer com os prisioneiros. O que vocês concluem então? 
Alunos:

\section{Atividade 2}

Leiam o texto a seguir e respondam as questões:

Em 2002, Silvio Santos lançou o seguinte jogo: várias pessoas respondiam perguntas e à medida que acertavam permaneciam no jogo, até restarem duas (as que acertavam todas as perguntas). Essas duas eram os jogadores que deveriam escolher entre as cartas "Sete" e "Meio".

Se os dois participantes escolhessem "Meio", dividiam um prêmio em dinheiro; se um escolhesse "Sete" e outro "Meio", o que tivesse escolhido "Sete" ganhava todo o prêmio sozinho; se os dois escolhessem "Sete", nenhum ganhava.

No jogo os jogadores podiam se comunicar antes de escolher, tentando combinar uma estratégia.

1 Descrevam todas as possibilidades e os respectivos ganhos ou perdas de cada jogador.

$2 \mathrm{Na}$ opinião de vocês, o que os jogadores devem combinar para obter o melhor ganho? Por quê? 


\section{(Lição de casa)}

Vamos conhecer um jogo de cartas, chamado Le Her. Toma-se um baralhos comum é composto de 13 cartas: Ás, cartas numeradas de 2 até 10; um Valete, Dama e Rei. Dois jogadores pegam uma carta cada um, sem mostrála para o outro, e colocam uma terceira na mesa, sem vê-la. Eles decidem quem joga primeiro. $O$ jogador 1 deve decidir se mantém a sua carta ou a troca com a carta do jogador 2, que não pode se recusar a fazer a troca. Depois, o jogador 2 deve decidir se mantém a sua carta ou a troca com a carta da mesa. Ganha quem tiver a carta de maior valor, dentre as três.

Jogue esse jogo e após, responda as questões:

- Em quais circunstâncias o primeiro jogador deveria trocar?

- E o segundo jogador, quando deveria trocar?

- Quais as semelhanças e diferenças deste jogo em relação aos anteriores (Dilema do Prisioneiro e Sete e Meio)? 
Alunos:

\section{Atividade 3}

Respondam essas questões seguintes:

Sobre a cena do filme Uma Mente Brilhante: qual foi a estratégia que o personagem usou para ninguém "sair" sozinho?

Sobre a situação apresentada na cena, o que há de semelhante e de diferente com as outras situações trabalhadas anteriormente? 


\section{UMA NOVA TEORIA}

Leiam atentamente o texto seguinte:

Existe uma teoria matemática que estuda situações como as que trabalhamos: Teoria dos Jogos.

Trata-se de uma teoria de modelos matemáticos que estuda escolhas ótimas para situações de conflito.

Um jogo é qualquer situação que envolva dois ou mais agentes (jogadores), onde cada decisão tomada por um, interfere nas decisões tomadas pelo outro; cada jogador só joga se existe a possibilidade de ter algum ganho.

O personagem visto na cena do filme "Uma Mente Briljante" trata-se de Jonh Nash, um matemático que contribuiu muito para essa teoria, ganhando o prêmio Nobel de economia em 1994.

Os jogos se dividem em dois tipos: Cooperativos (os jogadores buscam uma maneira de todos ganharem) e Competitivos (cada jogador procura ganhar dos outros)

A situação descrita na cena do filme Uma Mente Brilhante é um Jogo Cooperativo, enquanto que as situações trabalhadas anteriormente são Jogos Competitivos.

Dentro dos jogos Competitivos tem-se: Jogos de Soma Zero (para um jogador ganhar, o outro tem que perder. Exemplo: "par ou ímpar") e Jogos de Soma Não Zero (pode haver um benefício para ambos. Exemplo: "dois ou um").

A situação da atividade 1 chama-se "Dilema do Prisioneiro" e a situação da atividade 2 chama-se "Sete e Meio". Ambas são denominadas Jogos de Soma Não Zero.

A situação da atividade para casa cham-se "Le Her" e trata-se de um Jogo de Soma Zero.

Observem essa maneira de representar Jogos Competitivos (Tempo previsto: $5 \mathrm{~min}$ ). Chama-se Matriz de Payoff (A palavra payoff significa ganho):

\begin{tabular}{|c|c|c|c|}
\cline { 3 - 4 } \multicolumn{2}{c|}{} & \multicolumn{2}{c|}{ PRISIONEIRO B } \\
\cline { 3 - 4 } \multicolumn{2}{c|}{} & Confessar & Negar \\
\hline \multirow{2}{*}{ PRISIONEIRO A } & Confessar & $(-5,-5)$ & $(0,-10)$ \\
\cline { 2 - 4 } & Negar & $(-10,0)$ & $(-1,-1)$ \\
\hline
\end{tabular}

Nas situações de jogos de conflito sempre existe uma "solução", ou seja, uma possiblidade de ambos os jogadores fazerem as escolhas que são melhores para ambos, ao mesmo tempo. No caso da Matriz apresentada, (Confessar, confessar) é a solução do jogo. 
Alunos:

Atividade 4

Represente a Matriz de Payoff do jogo "Sete e Meio".

Indique a Solução: 
Alunos:

\section{Atividade 5}

Criem uma situação de jogo de conflito com dois jogadores. Digam se o jogo é: Cooperativo ou Competitivo. Se for Competitivo, diga se é de Soma Zero ou de Soma Não Zero. 
Alunos:

\begin{abstract}
Atividade 6
Leiam o texto (criado por outro grupo) e respondam essas questões seguintes:
\end{abstract}

1 - A situação de jogo proposta está bem definida?

2 - As estratégias de cada jogador estão claras?

3 - Caso necessário, reescreva de modo que realmente exista uma situação de jogo de conflito.

4 - Trata-se de um jogo Cooperativo ou Competitivo? 
5 - Soma Zero ou Soma Não-Zero (responda somente se o jogo for Competitivo)?

6 - Qual é a melhor estratégia para um dos jogadores?

7 - Qual é a melhor solução para esse jogo? 